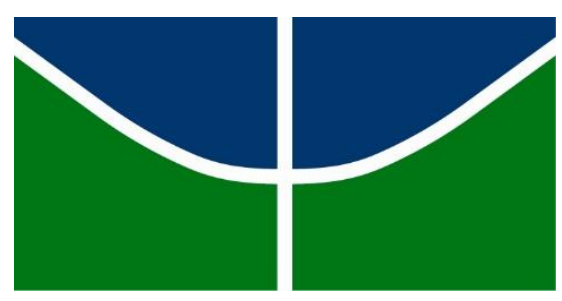

Universidade de Brasília

Instituto de Letras

Departamento de Linguística, Português e Línguas Clássicas

Programa de Pós-Graduação em Linguística

\title{
CAUSATIVIDADE EM LIBRAS
}

ALLINY DE MATOS FERRAZ ANDRADE

Brasília 


\author{
Universidade de Brasília - UnB \\ Instituto de Letras - IL \\ Departamento de Linguística, Português e Línguas Clássicas \\ Programa de Pós-Graduação em Linguística
}

\title{
CAUSATIVIDADE EM LIBRAS
}

\section{ALLINY DE MATOS FERRAZ ANDRADE}

\begin{abstract}
Dissertação apresentada ao Programa de Mestrado em Linguística do Departamento de Linguística, Português e Línguas Clássicas da Universidade de Brasília como requisito parcial de obtenção do título do mestre em Linguística.
\end{abstract}

Orientador: Prof. Dr. Dioney Moreira Gomes

$$
\text { Brasília - DF }
$$

Maio 


\author{
Universidade de Brasília - UnB \\ Instituto de Letras - IL \\ Departamento de Linguística, Português e Línguas Clássicas \\ Programa de Pós-Graduação em Linguística
}

\title{
DISSERTAÇÃO DE MESTRADO
}

\section{CAUSATIVIDADE EM LIBRAS}

Orientador: Prof. Dr. Dioney Moreira Gomes

Banca Examinadora:

Prof. Dr. Dioney Moreira Gomes (UnB/PPGL-LIP)

Prof $^{a}$. Dr ${ }^{a}$. Stella Telles de Araújo Pereira Lima (UFPE)

Prof $^{a}$. Dr ${ }^{a}$. Daniele Marcelle Grannier (UnB/PPGL-LIP)

Prof ${ }^{\mathrm{a}}$. Dr ${ }^{\mathrm{a}}$. Walkíria Neiva Praça (UnB/PPGL-LIP) 


\section{CAUSATIVIDADE EM LIBRAS}

Dissertação apresentada ao Programa de Mestrado em Linguística do Departamento de Linguística, Português e Línguas Clássicas da Universidade de Brasília como requisito parcial de obtenção do título do mestre em Linguística. (Área de Concentração Gramática: teoria e análise)

Aprovada em maio de 2015

Prof $^{\circ}$. Dro ${ }^{\circ}$ Dioney Moreira Gomes

Orientador / Presidente (UnB/PPGL-LIP)

Prof $^{a}$. Dr ${ }^{a}$. Stella Telles de Araújo Pereira Lima

Membro efetivo externo (UFPE)

Prof $^{\mathrm{a}}$. Dr ${ }^{\mathrm{a}}$. Daniele Marcelle Grannier

Membro efetivo interno (UnB/PPGL-LIP)

Prof $^{a}$. Dr ${ }^{a}$. Walkíria Neiva Praça

Membro suplente (UnB/PPGL-LIP) 
Dedico esta dissertação aos meus filhos, Gabriel e Nina, pelas lições diárias de amor. Dedico também aos/às surdos/as de Brasília, por me permitirem fazer parte da comunidade. 


\section{AGRADECIMENTOS}

Agradeço primeiramente a Deus, por me permitir caminhar até aqui;

Ao meu grande orientador, Professor Doutor Dioney Moreira Gomes, que, com muita paciência e compreensão, me orientou com seu conhecimento para a conclusão de mais esta etapa e que, por meio de seus exemplos, me orientou para a vida. Minha eterna admiração e gratidão;

Aos meus anjos, Mamusca e tio Toninho, que sempre me incentivaram a estudar e que, apesar da humildade de não compreenderem muito bem o porquê é tão difícil e demorado realizar uma pesquisa de mestrado, orgulham-se de mim;

Ao meu marido, João Paulo, pelo companheirismo e por aceitar que as únicas "DRs" que teríamos durante minha escrita da pesquisa seriam a discussão de relações gramaticais;

Aos meus filhos Gabriel e Nina, meus amores incondicionais;

Ao meu irmão Ryan, pela eterna parceria, apesar das diferenças;

Aos meus amigos surdos colaboradores, Amaury, Arislan, César, Cintia, Clésio, Falk, Liliane, Messias, Mariana e Rogério, por cederem parte de seu tempo colaborando com a pesquisa;

À Comunidade Surda, pelo apoio de sempre;

À FENEIS/DF - Federação Nacional de Educação e Integração dos Surdos do Distrito Federal, pelo convite para eu assumir a direção administrativa e com o cargo, todas as partilhas de tamanho aprendizado;

Ao CAS/DF (Centro de Capacitação de Profissionais de Educação e de Atendimento às Pessoas com Surdez), por instigar a me tornar uma pesquisadora;

Ao INOSEB - Instituto Nossa Senhora do Brasil e à Pastoral dos Surdos, local em que dei os primeiros "balbucios" em Libras;

Aos professores da Pós-Graduação da Universidade de Brasília, por tanto contribuir na minha formação; 
E, claro, não poderia deixar de agradecer aos amigos que caminharam ao meu lado, em especial, à minha amiga Tuxi, por acreditar em mim e me fazer acreditar que seria possível. Minha eterna gratidão! 


\section{RESUMO}

A causatividade é uma situação composta de dois eventos em que há um causador e um causado. Na construção de um enunciado causativo, associa-se um predicado de causa a um predicado de efeito. Algumas estratégias são utilizadas para aumentar a valência e trazer à cena esse "causador" para que, semanticamente, haja a possibilidade de construir enunciados causativos. Tais construções, consideradas como um fenômeno linguístico natural, já foram observadas e documentadas em várias pesquisas sobre línguas orais. Até o presente momento, sobre esse assunto muito pouco foi encontrado na literatura das línguas de sinais e não encontramos pesquisas sobre construções causativas em Libras, embora observemos sua presença no discurso. A presente pesquisa apresenta um estudo da sintaxe da Libras com a finalidade de documentar como os enunciados causativos são construídos em Libras, bem como algumas especificidades. Os dados revelaram que i) a Libras tem causativa perifrástica, ii) quando a causação é deliberada apresenta uma marcação peculiar com mais material linguístico que a outra causação menos volitiva, utilizando inclusive alguns sinais para atribuir maior volição ao causador, além de iii) apresentar repetições de partes do discurso para valorizar o superagente e a sua volição. As análises descritas partem de um olhar funcionalista por entendermos que o funcionamento de uma língua extrapola a preocupação exclusiva com competências para a organização gramatical de frases. Os dados registrados na pesquisa analisam a língua a partir do seu uso por falantes de Libras como língua materna.

Palavras - chave: Causatividade, causador, causado, Libras, superagente e volição. 


\section{ABSTRACT}

Causativity is a situation consisting of two events where there is a causer and a causee. In the construction of a causative statement, a predicate of cause is associated to a predicate of effect. Some strategies are used to increase valency and to bring in this "causer", so that, semantically, there is the possibility to construct causative statements. Such constructions, considered as a natural linguistic phenomenon, have already been observed and registered in various research papers on verbal languages. Up to the present moment, little has been found about this subject in the literature of sign languages, and we could not find research on causative forms in the Brazilian Sign Language (Libras), although we notice their presence in speech. The present research is a study of the Brazilian Sign Language syntax with the purpose to register how causative statements are constructed in this language (Libras), as well as some particularities. The data revealed that i) Libras has periphrastic causative constructions, II) when causation is deliberate, it shows a peculiar marking with more linguistic material than the other less volitional causation, also using some signs to attribute greater volition to the causer, in addition to III) showing repetitions of parts of the speech to value the super-agent and its volition. The analyses described are based on a functional approach, since we understand that the functioning of a language surpasses the exclusive concern regarding competencies for the grammatical organization of sentences. The data registered in the research analyze the language based on its use by speakers of Brazilian Sign Language as a mother tongue.

Key words: Causativity, causer, causee, Libras (Brazilian Sign Language), super-agent and volition. 


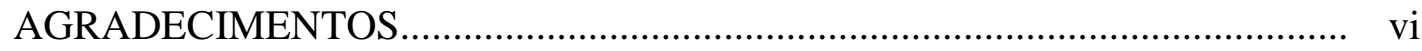

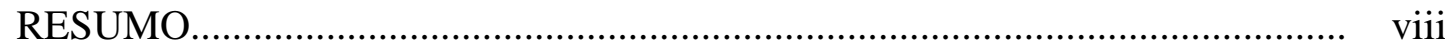

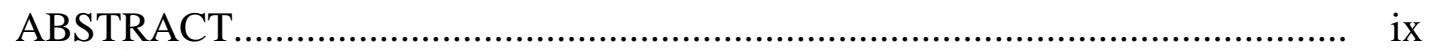

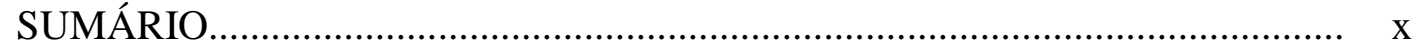

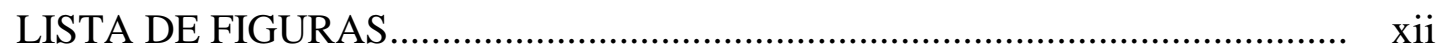

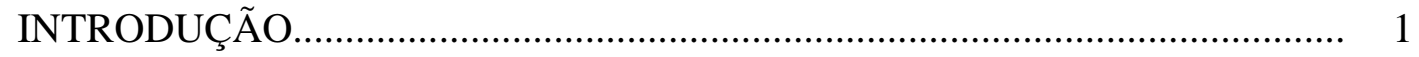

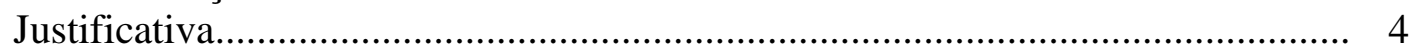

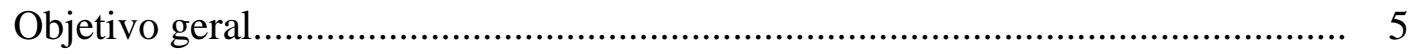

Objetivos específicos.............................................................................. 5

Metodologia, corpus e estrutura da dissertação................................................... 5

CAPÍTULO 1 - LÍNGUA DE SINAIS .................................................... 8

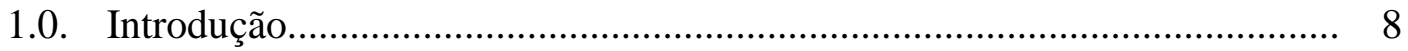

1.1. O que são línguas de sinais?................................................................. 8

1.2. Reconhecimento científico das Línguas de Sinais................................... 12

1.3. Características linguísticas das Línguas de Sinais..................................... 14

1.4. Considerações do capítulo........................................................................... 23

CAPÍTULO 2 - ESTUDOS SOBRE A SINTAXE DA LIBRAS....................... 24

2.0. Introdução................................................................................... 24

2.1. A sintaxe em Libras........................................................................ 24

2.2. Ordem dos constituintes em Libras....................................................... 25

2.3. Tipos de verbos em Libras.................................................................... 31

2.3.1. Verbos simples...................................................................... 33

2.3.2. Verbos com concordância.......................................................... 34

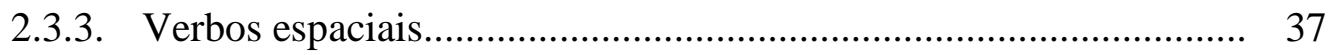

2.4. Incorporação em Libras?.......................................................................... 39

2.5. Considerações do capítulo...................................................................... 42

CAPÍTULO 3 - SINTAXE FUNCIONAL-TIPOLÓGICA E 43

CAUSATIVIDADE.

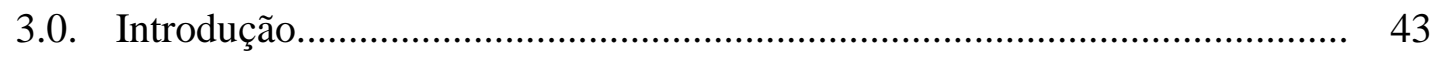

3.1. Funcionalismo e Tipologia ................................................................... 43

3.1.1. Relações gramaticais................................................................ 45

3.1.2. Papéis semânticos..................................................................... 47

3.1.3. Ordem de constituintes, tópico e topicalização................................ 50

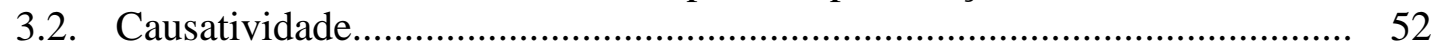

3.2.1. O que é causatividade?.......................................................... 54

3.2.2. Tipos de causatividade......................................................... 57

3.2.2.1. Causativas lexicais.................................................. 58

3.2.2.2. Causativas morfológicas............................................. 59

3.2.2.3. Causativas perifrásticas/analíticas................................. 59

3.2.3. Causação direta ou indireta?.................................................... 60

3.3. Considerações do capítulo..................................................................... 62

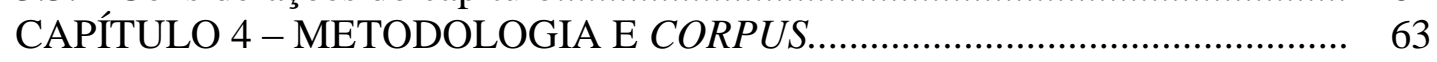

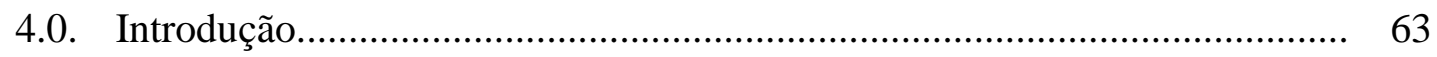

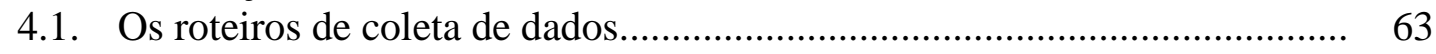

4.2. Os colaboradores surdos e a coleta de dados............................................ 68

4.3. Gravação dos vídeos...................................................................... $\quad 70$

4.3.1. Uso do software Elan................................................................. 71 
4.4. Considerações do capítulo......................................................................... 72

CAPÍTULO 5 - CAUSATIVIDADE EM LIBRAS ......................................... 73

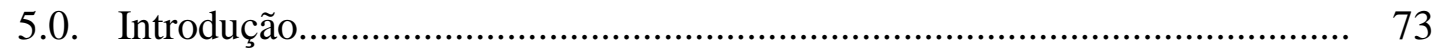

5.1. Análises e resultados versus a literatura corrente.................................... 73

5.2. Considerações do capítulo....................................................................... 98

CAPÍTULO 6 - CONSIDERAÇÕES FINAIS ................................................ 99

REFERÊNCIAS BIBLIOGRÁFICAS .................................................... 101

APÊNDICE A............................................................................ 107

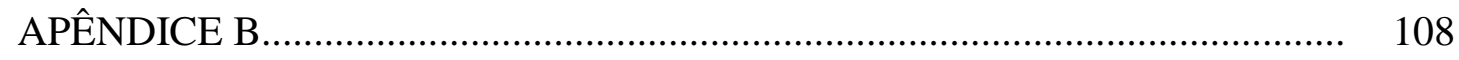




\section{LISTA DE FIGURAS}

Figura 1: Áreas de pesquisas comtempladas em dissertações de mestrado

(QUADROS, STUMPF e LEITE, 2013 p. 17)

Figura 2: Áreas de pesquisas contempladas em teses de doutorado (QUADROS, 3

STUMPF e LEITE, 2013, p. 18).

Figura 3: Sinal de CASA em ASL ( http: //www.lifeprint.com)............................ 13

Figura 4: Configuração de mão em B.............................................................. 13

Figura 5: Notação do sinal CASA, por Stokoe (1960) (http://scriptsource.org).... 13

Figura 6: A dança circular e a dança em 8 das abelhas ( LOPES, 1980, p. 36).... 15

Figura 7: Sinal “CORAÇÃO DE BEBÊ” (COSTA, 2012, p. 37)........................ 19

Figura 8: Sentença com argumentos reversíveis (QUADROS e KARNOPP, 27

2004, p. 159).

Figura 9: EU PERDER LIVRO PERDER (QUADROS e KARNOPP, 2004 p. 29 152).......

Figura 10: Verbos direcionais (STROBEL \& FERNANDES, 1998, p. 55)........... 31

Figura 11: Causação direta (SHIBATANI \& PARDESHI, 2002, p. 90)................ 61

Figura 12: Causação indireta (SHIBATANI \& PARDESHI, 2002, p. 90)............. 61

Figura 13: Pirâmide de iconicidade de Haiman (1983)........................................... 62 


\title{
INTRODUÇÃO
}

\author{
"Assunta isso: tudo que ele tá falando lá \\ a mulher faz nesse quadradinho, usando \\ of gestos? Será que dá pra falar tudo \\ mesmo? E sefor mentira? Sei não..." \\ (Minha amada avó, de infinita \\ sabedoria, desconfiada do processo de \\ tradução simultânea, na janela de \\ Libras, em uma missa transmitida na \\ televisão.)
}

Esse questionamento da minha avó não é algo isolado e é gerado tanto pela desconfiança do processo de tradução, como também pela desconfiança da própria língua de sinais. Seria possível a Libras ter essa riqueza capaz de transmitir qualquer mensagem? A resposta é sim!

É muito comum as línguas de sinais serem colocadas em xeque quando comparadas às línguas orais. Na visão do senso comum, as línguas de sinais não são vistas como línguas naturais, com o mesmo status linguístico; talvez, por isso, até hoje vemos um grande grupo de militantes surdos (pesquisadores ouvintes e demais simpatizantes) lutando pelo reconhecimento verdadeiramente pleno da língua.

Com o pioneirismo de William Stokoe no início da década de 1960, o que antes era visto como um emaranhado de gestos associados a um alfabeto manual (de uma língua oral qualquer), limitado e incapaz de transmitir conceitos abstratos, ganha um novo olhar. Mas por que então a dúvida, de muitos, sobre a veracidade de, entre outros exemplos, uma tradução simultânea? São mais de cinco décadas e ainda hoje nos deparamos com uma visão equivocada não somente fora da academia, mas dentro dela também. Obviamente, não deixaríamos de dar a devida relevância para as pesquisas surgidas desde então e que apresentam um número cada vez mais significativo, porém ainda são pequenos passos de uma longa trajetória.

No Brasil, as primeiras pesquisas, artigos e livros publicados sobre a Libras são da pesquisadora Ferreira-Brito, entre as décadas de 1980 e 1990, ao iniciar estudos 
apresentando as duas línguas de sinais utilizadas no Brasil: a Libras e a língua de sinais Urubu-Kaapor ${ }^{1}$. Anos mais tarde, Felipe, Karnopp, Quadros, Strobell fortalecem os estudos sobre a Libras. Um acontecimento que não pode ser ignorado é a Lei 10.436/2002, que reconhece a Libras como língua oficial da comunidade surda brasileira, e sua regulamentação, com o Decreto 5626/2005. Era a legislação também contribuindo para que os estudos sobre a Libras ganhassem força. Vária universidades, em parceria com a Universidade Federal de Santa Catarina, passaram a oferecer o curso Letras Libras e, a partir daí, centros de pesquisa surgiram em todo país. A título de ilustração:

Realizou-se um levantamento de teses e dissertações no banco da CAPES utilizando o termo 'Libras' e/ou língua de sinais no sistema de busca. No nível de mestrado foram localizadas 166 dissertações e no nível de doutorado foram localizadas 44 teses [...] A maioria dos estudos inclui a Libras como parte integrante da pesquisa sob diferentes enfoques, especialmente, com o foco no usuário da Libras ou na própria Libras. (QUADROS, STUMPF e LEITE, 2013, p. 15)

Com relação aos campos de investigação, estão distribuídos nas mais diferentes áreas de pesquisa, como mostram os gráficos a seguir:

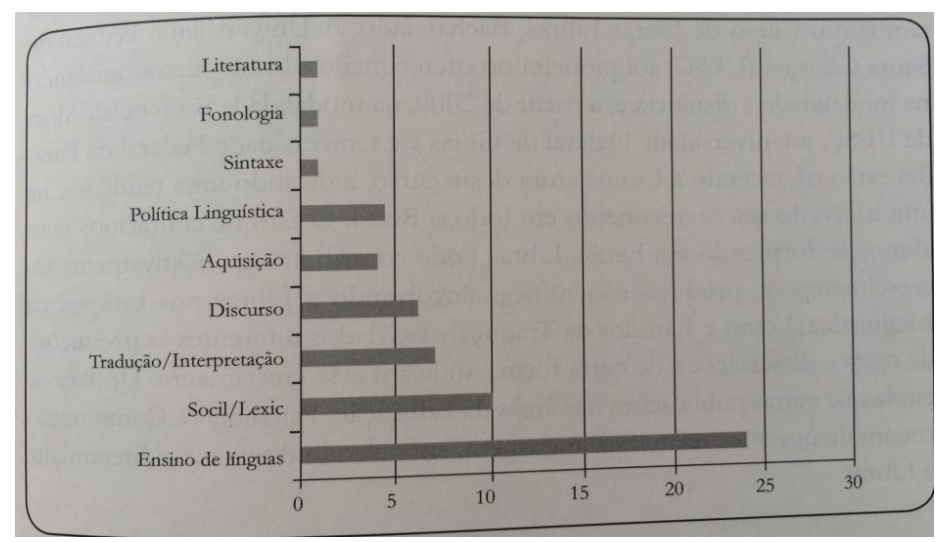

Figura 1: Áreas de pesquisas contempladas em dissertações de mestrado

(Fonte: QUADROS, STUMPF e LEITE, 2013, p. 17)

\footnotetext{
${ }^{1}$ Língua de sinais utilizada pela comunidade indígena Urubu-Kaapor no interior do Maranhão.
} 


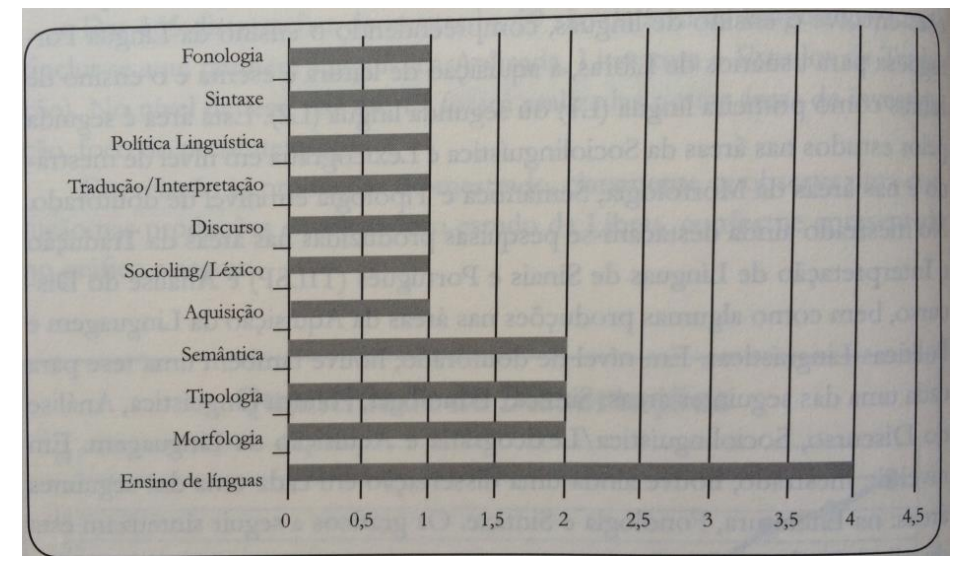

Figura 2: Áreas de pesquisas contempladas em teses de doutorado (Fonte: QUADROS, STUMPF e LEITE, 2013, p. 18)

Apesar das pesquisas estarem aumentando consideravelmente, ao observar os gráficos, é possível perceber que o "ensino de línguas" é o campo mais investigado tanto em pesquisas de mestrado quanto de doutorado. E também é possível perceber a carência nas mais diversas áreas, sobretudo no campo da gramática.

Embora saibamos que a política, ao reconhecer a Libras como língua no Brasil, impulsionou as mais diversificadas pesquisas, seria leviano não dar a devida relevância às lacunas existentes aos estudos da Libras, sobretudo na área da sintaxe, da semântica e da pragmática.

Durante minhas aulas da pós-graduação no PPGL, na UnB, tínhamos o hábito de "ventilar" possibilidades nas mais diferentes línguas. Indígenas, surdos e falantes de outras línguas. Em Português, por exemplo, é muito comum enunciados como:

1) - O copo caiu.

2) - O menino derrubou o copo.

3) - O menino fez o copo cair.

Como ficariam os mesmos enunciados em Libras, especialmente os enunciados $2 \mathrm{e}$ 3? São sentenças possíveis?

No presente trabalho, pretendemos pesquisar como ocorrem as construções causativas em Libras e quais seriam as estratégias apresentadas na língua para acrescentar o predicado de causa no discurso. Para isso, buscamos maior compreensão sobre o assunto 
nas pesquisas de Shibatani (1985), Neves (1997), Payne (1994, 1997), Givón (2001), Cunha (2003), Gomes (2006), entre outros.

\section{Justificativa}

Nossa pesquisa ocupa-se do estudo dos meios linguísticos de expressão e rejeita a preocupação exclusiva com a pura competência para a organização gramatical das frases. Pensando na linguagem como algo dinâmico, em que os componentes linguísticos (sintático-semânticos) são analisados na interação verbal (componente pragmático).

A pesquisa apresenta como justificativa a carência de observações e análises de fenômenos comuns às diversas línguas: a causatividade. Estudos de línguas orais revelam que a causatividade varia na forma como se expressa. Para Shibatani (1976), algumas línguas utilizam procedimentos morfológicos, outras sintáticos e um terceiro grupo compreende aquelas que apresentam procedimentos tanto morfológicos como sintáticos. Givón (2001) define uma "situação causativa", em uma relação entre dois eventos, um evento-causa e um evento-efeito, de tal forma que a ocorrência do evento-efeito é inteiramente dependente do evento-causa. E em Libras? Como dizer:

4) João saiu.

5) Eu fiz João sair.

6) Eu forcei João a sair.

7) Eu causei a saída de João.

A literatura mostra que, em algumas línguas orais, há três tipos de construções causativas: i) lexicais; ii) morfológicas; e iii) perifrásticas. E na Libras? O que revela a sintaxe, a semântica e a pragmática da Libras?

Por fim, o presente trabalho pode vir a contribuir na produção de materiais didáticos pertinentes ao ensino de português escrito para surdos, partindo do princípio que, ao buscar na literatura sobre Libras, nada foi encontrado sobre as construções causativas. Observada mais essa lacuna na descrição do fenômeno, torna-se interessante 
refletir sobre o material utilizado em sala de aula (ou a ausência dele) para apresentar aos estudantes surdos o que é a causatividade e como ela é construída em Libras, para que, somente então, possamos pensar nas construções causativas da língua portuguesa e estabelecer, por exemplo, possíveis semelhanças e diferenças ao observar as duas línguas. Por exemplo, nos enunciados (5), (6) e (7), qual seria a forma mais natural e real? As três formas são possíveis em Libras?

\section{Objetivo geral}

Identificar as estratégias usadas em Libras para acrescentar o predicado de causa no discurso - causatividade.

\section{Objetivos específicos}

a) Diferenciar predicado de efeito de predicado de causa;

b)Explicitar as estratégias usadas para acrescentar um (novo) personagem/argumento/participante que seja superagente (causador);

c) Analisar a ordem das palavras na construção do predicado de causa + predicado de efeito;

d) Contrastar a causatividade em Libras com a causatividade já registrada/estudada em outras línguas.

\section{Metodologia, corpus e estrutura da dissertação}

A pesquisa teve a participação de um corpo de colaboradores composto por participantes surdos, que se comunicam exclusivamente por meio da Libras, com o 
objetivo de evitar que línguas de contato, como o Português, interferissem nos resultados. $^{2}$

A coleta de dados aconteceu com a assinatura do Termo de Consentimento Livre e Esclarecido (TCLE) ${ }^{3}$ dos colaboradores, e com o preenchimento de um questionário sociolinguístico contendo algumas questões pertinentes à pesquisa: nome; idade; sexo; escolaridade; grau de surdez; como/quando/onde e com quem aprendeu Libras; se a família sabe Libras. O objetivo era conhecer a trajetória linguística dos colaboradores e compreender o processo da aquisição da Libras.

Os participantes foram filmados, fazendo elicitações com construções causativas previamente selecionadas por nós, a partir de imagens e elicitações escritas em português, para que, posteriormente, pudéssemos analisar estas sequências produzidas, individualmente, por cada um de nossos colaboradores, em Libras. No capítulo 4, apresentaremos mais detalhes.

O ELAN foi utilizado como ferramenta de análise dos dados. Durante esse processo de análise, contamos com o apoio dos próprios surdos na elaboração dos resultados das análises, aspecto que consideramos demasiadamente positivo para a pesquisa. No capítulo 4, voltaremos a tratar da metodologia usada na construção desta dissertação, oferecendo mais detalhes sobre os caminhos trilhados por nós.

\footnotetext{
${ }^{2}$ Os surdos, moradores de Brasília, durante as décadas de 70, 80 e 90, sofreram uma política de ensino muito focada na metodologia oralista. Os surdos que aqui moravam, se desejassem o ingresso escolar, não tinham muitas opções de escolha, pois a única instituição adotava a metodologia oralista e não permitia que os alunos tivessem contato com a Libras. Atualmente, tal instituição continua atendendo $o$ alunado surdo, mas com o reconhecimento da Libras como língua, pela Lei 10.436 / 2002, e a regulamentação desta pelo Decreto 5.626/ 2005, outras instituições públicas e privadas, com metodologias diferenciadas, passaram a atender alunos surdos, hoje, por exemplo a família ou o próprio surdo tem o poder de decidir se deseja estudar em uma escola oralista ou bilíngue.

${ }^{3}$ Procuramos o Comitê de Ética em Pesquisa do Instituto de Ciências Humanas (CEP/IH), da Universidade de Brasília, para submissão da pesquisa, mas não conseguimos emissão do parecer. Ao cadastrar o projeto na Plataforma Brasil, local em que os projetos são detalhados, ocorreu um erro e a página não registrou a instituição proponente (Universidade de Brasília). Apesar de tentarmos contatos via telefone, email, atendimento on-line (na própria plataforma) e visitas ao Comitê, não foi possível concluir o processo de submissão. Realizaram uma reforma nas instalações do Comitê e, em seguida, mudaram de endereço. $\mathrm{Na}$ sequência, a greve dos servidores responsáveis pelo setor impossibilitou a retificação necessária para a conclusão da análise e submissão. Mesmo assim, tomamos todas as medidas éticas previstas em trabalhos desta natureza.
} 
O quadro teórico usado foi o funcionalismo-tipológico, o qual será abordado no capítulo 3.

Assim, a presente dissertação está dividida em cinco capítulos: no capítulo 1, fazemos uma introdução sobre as línguas de sinais, seu reconhecimento científico e suas características linguísticas; no capítulo 2, propomos uma revisão sobre o que já se produziu sobre a sintaxe em Libras; no capítulo 3, apresentamos nosso referencial teórico; no capítulo 4, revelamos os passos da pesquisa com a metodologia utilizada; e, no capítulo 5, analisamos sentenças em Libras e observamos como os colaboradores expressam as construções causativas em Libras. 


\section{CAPÍTULO 1 - LÍNGUAS DE SINAIS}

\subsection{Introdução}

O objetivo deste capítulo é oferecer ao leitor um panorama histórico sobre as línguas de sinais e apresentar o seu processo de legitimação enquanto língua. O presente capítulo está dividido em três seções. A seção 1.1 define o que são línguas de sinais. Na seção seguinte, é apresentado o reconhecimento científico das línguas de sinais. Por fim, na seção 1.3 são apontadas as propriedades mais específicas que contribuem para a flexibilidade e versatilidade das línguas de sinais.

\subsection{O que são línguas de sinais?}

Falar em língua de sinais e seu reconhecimento linguístico ainda requer falar sobre legitimação de uma língua que há mais de cinquenta anos conquistou esse status. Não é incomum, porém, indagações como: i) Gestos, pantomimas e sinais são tão próximos; seria possível apresentar a linha extremamente tênue que os separa? ii) Sobre a linguagem de sinais, ela é totalmente icônica? e iii) Se, em língua de sinais, eu tenho a representação gestual da língua portuguesa, como é possível afirmar que na Libras, por exemplo, existe uma gramática? Esses são apenas alguns questionamentos e equívocos muito rotineiros com que ainda nos deparamos no dia-a-dia.

Quadros e Karnopp, na obra Língua de Sinais Brasileira / Estudos linguísticos (2004, p. 31-37), elencam 6 mitos sobre algumas dessas curiosidades. Desses, citamos por exemplo, Haveria uma única e universal língua de sinais usada por todas as pessoas surdas. Já Audrei Gesser, da Universidade Federal de Santa Catarina, em 2009 publicou um livro bastante interessante sobre algumas dessas questões, intituladas mitos, e outras mais, que também carecem de ser desmitificadas; para isso, dedica um capítulo inteiro da obra, totalizando 12 questões, que envolvem universalidade, artificialidade, iconicidade das línguas de sinais e outras temáticas.

Como definir língua? E linguagem? Viotti (2008, p. 3) afirma que: 
Para Saussure, linguagem é uma faculdade humana, uma capacidade que os homens têm para produzir, desenvolver, compreender a língua e outras manifestações simbólicas semelhantes à língua. A linguagem é heterogênea e multifacetada: ela tem aspectos físicos, fisiológicos e psíquicos, e pertence tanto ao domínio individual quanto ao domínio social. Para Saussure, é impossível descobrir a unidade da linguagem. Por isso, ela não pode ser estudada como uma categoria única de fatos humanos. A língua é diferente. Ela é uma parte bem definida e essencial da faculdade da linguagem. Ela é um produto social da faculdade da linguagem e um conjunto de convenções necessárias, estabelecidas e adotadas por um grupo social para o exercício da faculdade da linguagem. A língua é uma unidade por si só. Para Saussure, ela é a norma para todas as demais manifestações da linguagem. Ela é um princípio de classificação, com base no qual é possível estabelecer uma certa ordem na faculdade da linguagem.

Porém, quando se chama uma língua de sinais de "linguagem de sinais", o que está por trás desse último termo é a visão equivocada de que não se trata de língua, mas sim de um tipo de linguajar, de código limitado, de algo apenas próximo a língua.

Para Gesser (2009), enxergar e apresentar as línguas de sinais como línguas ainda é um desafio:

O que vemos é que o discurso aparentemente "gasto" [sobre Libras ser uma língua ou não] faz-se necessário, precisando ser repetido inúmeras vezes para que a constituição social dessa língua minoritária ocorra, ou seja, para chegarmos à legitimação e ao reconhecimento, por parte da sociedade como um todo, de que a língua de sinais é uma língua. (GESSER 2009, p 9)

Talvez a resistência na aceitação enquanto língua esteja ainda associada à relação língua de sinais e deficiência, em que a comunicação é utilizada por pessoas deficientes, e, socialmente, vistas como inferiores e incapazes. Para Lima (2006, p. 41),

\footnotetext{
O status social negativo das línguas de sinais está intimamente ligado à história da educação dos surdos no mundo. Esta história é marcada por desmandos e abusos daqueles que construíram posições-de-sujeitos para os surdos tomando a si próprios como ponto de referência, como normais, verdadeiros modelos de ser humano. Um desses marcos tão onerosos aos surdos em todo o mundo foi o Congresso de Milão, em 1880, cujas atas finais definiram as propostas educacionais no fim do século XIX e as políticas públicas (inclusive no Brasil) até cerca de 1970. A ordem era oralizar, normatizar, fazer o surdo falar, ser como os ouvintes, ser normal.
}

Desde o Congresso de Milão (1880), iniciou-se o processo intitulado por Lima (2006) como colonização cultural do povo surdo, em que o território dos surdos foi 
invadido, e a língua, a cultura e a arte foram cassadas e reprimidas. Sem dúvida, poderia essa ser uma (pseudo)justificativa para compreendermos o porquê do desprestígio das línguas de sinais, afinal, ela ainda é observada com uma certa desconfiança, por muitos.

Hoje em dia, por outro lado, um número crescente de pesquisadores vem aumentando o interesse em estudos nessa área, o que não implica dizer que a área não carece de mais pesquisas. Eles se dedicam a investigar línguas visuoespaciais, que nasceram e são transmitidas, assim como as línguas orais, de forma natural, sendo capazes de expressar qualquer situação, seja ela simples, complexa, concreta ou abstrata.

Goldfeld (1997) faz um levantamento de fatos históricos relevantes sobre os surdos, suas línguas de sinais e as instituições sociais. Ele apresenta, como primeiro registro da educação dos surdos em língua de sinais, o trabalho do educador monge Pedro Ponce de Leon (1520-1584), na Espanha, ocasião em que se trabalhava a oralização concomitantemente com a utilização de um alfabeto manual. De acordo com a autora, em 1644, J. Bulwer publicou o primeiro livro em inglês sobre língua de sinais e, anos mais tarde, em 1648, com a publicação da obra Philocopus, iniciou-se um trabalho equiparando línguas de sinais às línguas orais. Na França, em 1760, o abade L’Epée assumiu um trabalho formal com surdos encontrados nas ruas de Paris, em que oralidade, alfabeto manual e criação dos primeiros sinais misturavam-se em uma metodologia que conquistou o reconhecimento de alguns estudiosos. Como resultado, L'Epée fundou o primeiro Instituto de Surdos e Mudos de Paris (atual Instituto Nacional de Jovens Surdos), enveredando para uma educação, cuja metodologia utilizada atendia às necessidades dos sujeitos surdos. Em 1817, Thomas Hopkins Gallaudet, depois de conhecer o instituto francês, fundou a primeira escola para surdos nos Estados Unidos. Encantado com o trabalho que conheceu lá na Europa, trouxe o projeto para América e, no ano de 1821, este trabalho, pioneiro nos Estados Unidos, passou a buscar a ASL (Língua de Sinais Americana) como língua de instrução. Surpreendentemente, em 1880, no famoso Congresso de Milão (Congresso Internacional de Educadores de Surdos), cujo objetivo era reunir professores de diferentes países para discutir metodologias voltadas para educação de surdos, ocorre um enorme retrocesso:

Nesse congresso, foi colocado em votação qual método deveria ser utilizado na educação dos surdos. O oralismo venceu e o uso da língua de sinais foi oficialmente proibido. Aos professores surdos foi negado o direito de votar. Naquele momento, a educação dos surdos deu uma grande reviravolta em 
sentido oposto à educação do século XVIII, quando a sociedade percebeu a potencialidade dos surdos com a língua de sinais. (GOLDFELD, 1997, p. 31)

Mais uma vez, impor o oralismo significa normatizar e padronizar o processo de educação, sem respeitar as diferenças. Língua de sinais, nesse contexto, é apenas uma decorrência paliativa para minimizar as limitações da deficiência e fazer da comunicação, um processo possível, ainda que falho. Como reconhecer as diversas nuances linguísticas de uma língua já tão estigmatizada? Seria mesmo uma língua? Se sim, provavelmente vista por muitos pesquisadores (sobretudo os oralistas) como fadada ao fracasso. E nos anos seguintes, a literatura não menciona mudanças significativas. A oralização era o principal objetivo da escola, enquanto nas diversas disciplinas os conteúdos não eram trabalhados. Temos, então, o primeiro registro da queda do nível de escolarização dos surdos, segundo Goldfeld (1997). Embora haja esse processo de repressão das línguas de sinais, a professora surda Karin Strobel (2008) afirma que:

\begin{abstract}
A língua de sinais é transmitida nas comunidades surdas e, apesar de por muito tempo na história dos surdos ter sofrido a repressão exercida pelo oralismo, a língua de sinais não foi extinta e continuou a ser transmitida, de geração em geração, pelos povos surdos com muita força e garra. [...] A partir da década de 1950 iniciaram-se estudos aprofundados sobre as línguas de sinais como, por exemplo, o do americano William Stoke (1965) e, no Brasil, dos ouvintes Lucinda Ferreira Brito (1986), Ronice Quadros (1995; 2004), Tanya Felipe (2002) e Lodenir Karnopp (2004) e os surdos linguistas Ana Regina e Souza Campelo (2007) e Shirley Vilhalva (2007), que proporcionaram a valorização da língua de sinais, dando-lhes status de uma língua legítima do povo surdo.
\end{abstract}

(STROBEL 2008, p. 46)

Somente em 1957, William Stokoe, um professor da Gallaudet ${ }^{4}$, em Washington, inicia pesquisas levantando hipóteses sobre a relação entre línguas orais, línguas de sinais e línguas naturais. Anos mais tarde, em 1960, ele concluiu parte dos estudos com a primeira descrição de uma língua de sinais, na obra intitulada A dictionary of American Sign Language on linguistic principles, sem dúvida, um grande marco para o reconhecimento científico das línguas de sinais, como veremos na próxima seção.

\footnotetext{
${ }^{4}$ Importante universidade com programas e serviços voltados para surdos e pesquisadores das línguas de sinais. www.gallaudet.edu
} 


\subsection{Reconhecimento científico das Línguas de Sinais}

O panorama ilustrado na seção anterior, sobre parte do percalço das línguas de sinais e o processo de (des)escolarização, foi utilizado para melhor entendermos o marco que significou os primeiros estudos linguísticos de William Stokoe, num trabalho pioneiro. E, por esse motivo, é muito comum encontrarmos, na literatura, análises descritivas em ASL - Língua de Sinais Americana.

Stokoe, durante sua pesquisa, comprovou que a ASL não era um sistema falho do inglês no alfabeto datilológico e coberto de lacunas como pensavam muitos. Os sinais passaram a ser vistos como algo muito além de gestos e mímicas. Seu interesse pelas unidades constituintes de uma língua de sinais, elevou as pesquisas na área. Os estudos de Stokoe pautavam-se nos itens lexicais da ASL, equiparando-os às palavras das línguas orais, por serem passíveis de decomposição em unidades menores. Nascia aí o reconhecimento de uma língua de sinais como língua natural, a partir de registros das primeiras análises linguísticas de uma língua de sinais.

\footnotetext{
Quando o estudo de Stokoe (1960) foi publicado, a existência de uma notação para registrar sua estrutura fonológica era argumento importante para garantir às línguas de sinais o status de língua verdadeira. $\mathrm{O}$ fato de que uma língua de sinais poderia ser representada na forma escrita como sendo composta de um conjunto de subpartes sistematicamente estruturadas foi argumento para o reconhecimento de seu status linguístico (MILLER, 1994 apud AMARAL 2012)
}

Na proposta de Stokoe (1960), um item lexical na ASL era formado de elementos chamados de queremas (do grego khéir, mão), evitando a denominação fonema e a etimologia relacionada ao som (LEITE, 2008). Inicialmente, três aspectos foram propostos como elementos da estrutura interna dos sinais, que ocorrem simultaneamente ou não a depender do prisma teórico adotado na pesquisa:

- Designator: configuração de mão. Disposição dos dedos durante a produção dos sinais.

- Tabula: localização. Lugar no corpo ou em frente a ele em que os sinais são realizados.

- Signation: movimento. Forma como a mão se desloca no espaço para articular um sinal. 
Para exemplificar a proposta de Stokoe, ilustremos, com as Figuras 3, 4 e 5, em ASL, o sinal de CASA e sua respectiva notação:

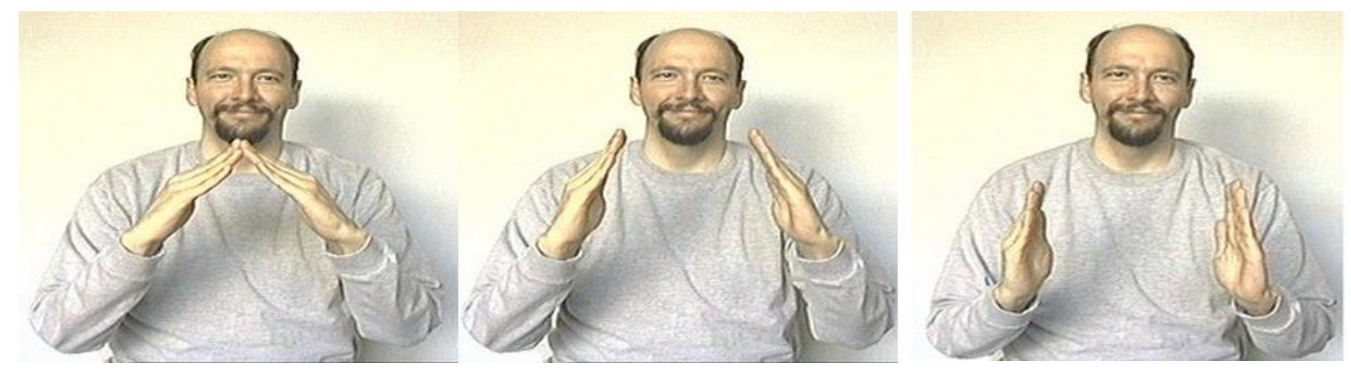

Figura 3: sinal de CASA em ASL ${ }^{5}$

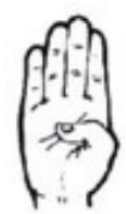

Figura 4: Configuração de mão em B

Ao repararmos nas mãos do sinalizante (designator), as mesmas estão configuradas em B - Figura 4. As mãos estão localizadas (tabula) inicialmente, em frente ao peitoral. Movendo-as (signation), elas se tocam e, na sequência, de forma espelhada, o sinalizante afasta-as para baixo. Assim, ao associar os três elementos, é sinalizado o item lexical CASA.

Nos estudos de Stokoe, foi desenvolvido um sistema de notação para o registro dos sinais. Ao realizar, por exemplo, o sinal CASA, utilizando as mãos configuradas em B (ilustrado na Figura 2), Stokoe (1960) considerou que, para realizar o registro escrito, deveria tomar nota sem desconsiderar a configuração de mão em B. O resultado dessa notação para o sinal de CASA é a figura 5 a seguir:

\section{$\mathrm{B}_{\Lambda}{ }^{\prime} \mathrm{B}_{\Lambda} \dot{\vec{v}}$}

Figura 5: Notação do sinal CASA, por Stokoe $(1960)^{6}$

\footnotetext{
${ }^{5}$ Disponível em http://www.lifeprint.com/ acessado em 20/11/2014.

${ }^{6}$ Disponível em http://scriptsource.org/ acessado em 24/11/2014.
} 
Interessante observarmos a letra B na notação, evidenciando a configuração de mão em B. Trata-se de um registro não pautado nos registros convencionais das línguas orais (o sistema alfabético). Posteriormente, outros pesquisadores desenvolveram vários sistemas de notação ${ }^{7}$ para as línguas de sinais (LS). No Brasil, um sistema muito utilizado como registro da Libras é o SignWriting. Segundo Stumpf (2008), através de um modo gráfico esquemático, com mais de 900 símbolos, o SignWriting é capaz de registrar qualquer língua de sinais sem passar pela tradução da língua falada.

Uma vez adquirido o reconhecimento científico, as línguas de sinais passaram a ser pesquisadas em diversos países. Falava-se antes em um emaranhado de gestos desarticulados, mas que passaram na era pós-Stokoe a ser vistos como "estruturas multiarticuladas e multiniveladas, com base nos mesmos princípios gerais de organização que podem ser encontrados em qualquer língua” (BEHARES, 1993, p. 43).

Foi dado o primeiro passo para um (re)olhar sobre as línguas de sinais como línguas naturais. Sobre as características linguísticas que viabilizaram esse primeiro passo de uma longa e difícil caminhada, discutiremos em nossa próxima seção.

\title{
1.3. Características Linguísticas das Línguas de Sinais
}

\begin{abstract}
Não há diálogo entre as abelhas. [...] A mensagem de uma abelha não pode ser reproduzida por outra que não tenha visto ela mesma os fatos que a primeira anuncia. [...] A abelha não transmite ou retransmite uma mensagem, assim, não há comprovação de que uma abelha vá, por exemplo, levar a outra colmeia uma mensagem que recebeu na sua. [...] A mensagem das abelhas não se deixa analisar. (BENVENISTE, 2005, p. 61)
\end{abstract}

Benveniste (2005) dedica um capítulo para enaltecer as diferenças entre comunicação animal e linguagem humana. O pesquisador nos convida para uma reflexão sobre os diferentes meios de comunicação, pensando nas abelhas. Em 1959, Karl von Frisch publica um livro sobre a comunicação das abelhas, no qual revelava que uma abelha obreira, ao encontrar alimento, regressava à colmeia para repassar a informação às companheiras e utilizava-se de duas formas de dança (cf. Fig. 6)

\footnotetext{
${ }^{7}$ Para aprofundar sobre notações de línguas de sinais, ler Miller (1994).
} 

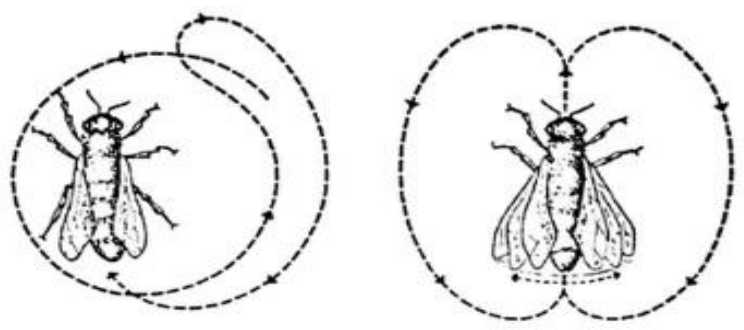

Figura 6: A dança circular e a dança em 8 das abelhas (LOPES, 1980, p. 36)

O estudo revelou que a oscilação entre as danças à esquerda e à direita, apresentadas na Fig. 6, era capaz de revelar a distância e a direção do local onde encontrariam alimento. Lopes (1980) afirma que, ao voltar de uma distância relativamente próxima, a abelha realizava movimentos circulares e, diferentemente, o movimento "em 8" era executado quando as distâncias não eram tão próximas. O estudo descrito por Lopes (1980) e as observações de Benveniste (2005) concordam que, apesar de haver comunicação entre as abelhas, é algo infinitamente limitado se comparado às possibilidades da língua humana. E, segundo eles, uma das características fundamentais atribuídas às línguas humanas é a necessidade de um aparelho vocal. Esqueceram-se dos surdos que usam línguas de sinais.

Os estudos linguísticos avançaram e, com eles, a compreensão de que os surdos criaram, desenvolveram e transmitiram, de geração em geração, uma língua natural, complexa e abstrata, numa modalidade de recepção e produção diferente da utilizada por ouvintes, a modalidade visuoespacial (SÁ, 2002, p. 107).

De acordo com Lyons (2009), para ser considerada uma língua natural (diferente de outros meios de comunicação), duas características, talvez as mais gritantes de uma língua, são a flexibilidade e a versatilidade.

Podemos usar a língua para dar vazão a nossas emoções e sentimentos, para solicitar a cooperação de nossos companheiros; para ameaçar ou prometer; para dar ordens, fazer perguntas ou afirmações. Podemos referir-nos ao passado, presente e futuro; a realidades remotas em relação à situação da enunciação - até mesmo a coisas que não precisam existir ou não podem existir. Nenhum outro sistema de comunicação parece ter sequer de longe o mesmo grau de flexibilidade e versatilidade. Dentre as propriedades mais específicas que contribuem para a flexibilidade e versatilidade destacam-se: arbitrariedade, dualidade, descontinuidade e produtividade. (LYONS, 2009, p. 14) 
Ao pensar em arbitrariedade, a primeira questão que nos vem em mente é a conexão arbitrária entre forma e significado como se tivéssemos uma forma, mas não pudéssemos prever o significado ou ainda; ou tivéssemos um significado, mas sem prever a forma. Embora muitos pesquisadores reconheçam acertadamente o caráter icônico das línguas de sinais, a arbitrariedade é uma propriedade também presente nelas. ${ }^{8}$ Observemos a arbitrariedade no sinal BANHEIRO em Libras e ASL:

(1)

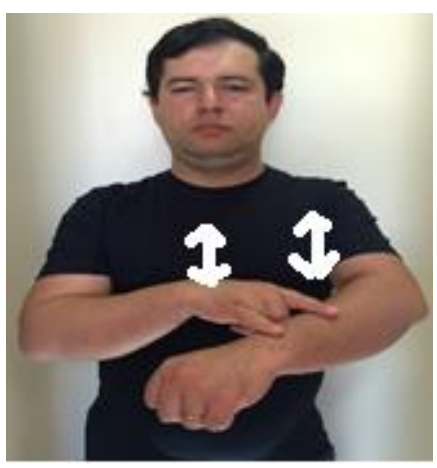

BANHEIRO em Libras

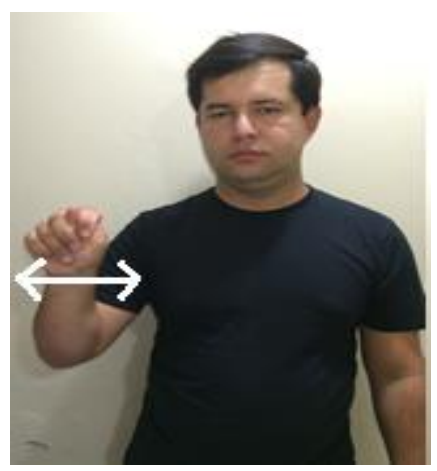

BANHEIRO em ASL

A dualidade é definida por Lyons (2005) como a propriedade da língua de possuir dois níveis de estrutura, de tal forma que as unidades do primeiro são compostas de elementos do segundo, com suas especificidades de organização. Essa também é propriedade presente nas línguas de sinais. Podemos perceber essa propriedade na constituição de um sinal. Os elementos envolvidos aí são denominados parâmetros ${ }^{9}$, que se organizam para atribuir significado a um item lexical. Mais à frente, voltaremos a falar dos parâmetros.

Observemos o sinal do verbo TER (em Libras): ao configurar a mão em L, necessita-se, simultaneamente, de outros parâmetros para execução do sinal:

\footnotetext{
${ }^{8}$ É preciso dizer que o caráter icônico das línguas de sinais não diminui o seu valor enquanto língua. Muito pelo contrário, à medida em que a Linguística avança nos estudos sobre a tipologia das línguas e sobre as línguas de sinais, fica mais e mais evidente que a iconicidade pode também ser uma propriedade das línguas naturais. Há correntes linguísticas que identificam a iconicidade em níveis estruturais acima do nível da palavra. Há, por exemplo, causativas lexicais (de extensão curta) frente a causativas sintáticas (de extensão longa), e diferenças semânticas entre elas. No capítulo 3, falaremos disso.

${ }^{9}$ Utilizaremos o conceito de parâmetros adotado por Quadros e Karnopp (2004, p. 47), que o definem como as unidades mínimas que se combinam na formação de um sinal.
} 
(2)

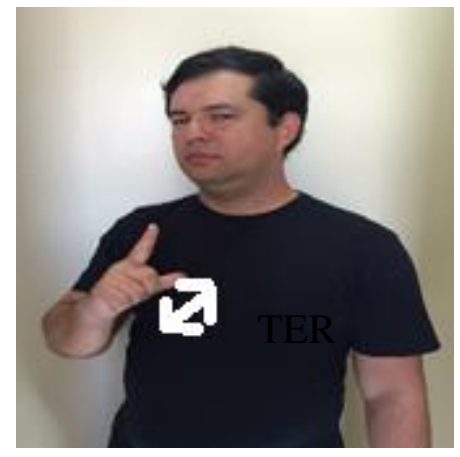

Caso a mão toque uma outra parte do corpo que não o tronco (conforme a imagem acima tenta mostrar), teríamos outros sinais com outras significações. Daí a importância de ressaltar que um parâmetro isolado não apresenta significado. $O$ sinal passa a receber um significado somente quando os parâmetros são combinados entre si.

A produtividade observada nas línguas de sinais possibilita a construção e interpretação de novos enunciados. Um conjunto finito de regras é utilizado para a construção e compreensão infinita de sentenças. A Libras permite, por exemplo, enunciados como:

É possível comparar a comunicação das abelhas com a língua humana?
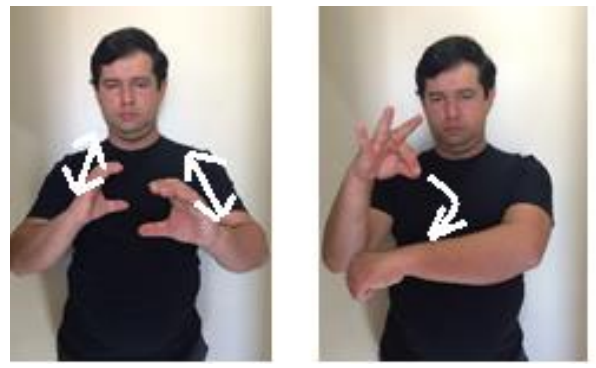

COMUNICAÇÃO

ABELHA

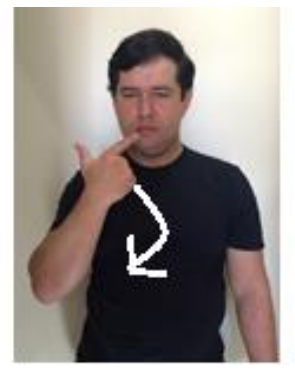

LÍNGUA

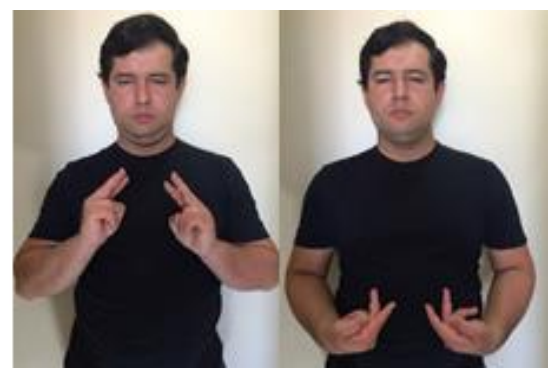

HUMANA

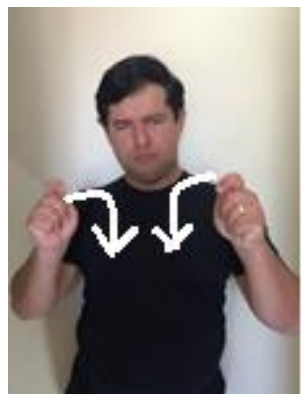

POSSIBILIDADE

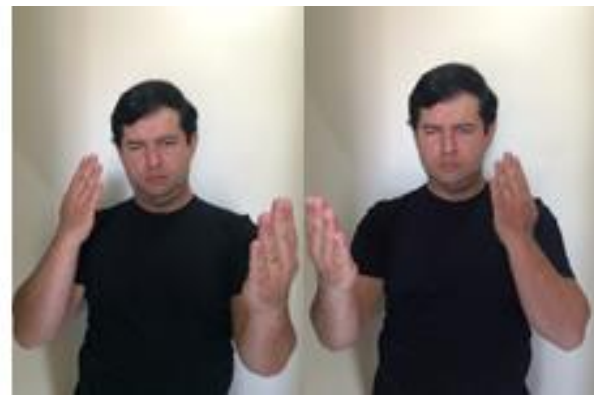

COMPARAÇÃO 
Percebemos que a sentença produzida em Libras combina diferentes itens lexicais, que nos levam à cena discursiva, como também ocorre nas línguas orais. Por fim, novos sinais são sempre criados a partir dos componentes dos sinais já existentes (parâmetros) desde que haja contexto para isso e necessidade pragmática e semântica.

Todos os exemplos apresentados anteriormente, em ASL ou Libras, foram utilizados para ilustrar alguns princípios descritos nos estudos de línguas orais, capazes de evidenciar a flexibilidade e a versatilidade das línguas e certificá-las enquanto língua natural. Pensando nesses princípios concatenados, reafirmamos o que a literatura linguística das últimas décadas tem afirmado: as línguas de sinais são, de fato, línguas naturais. A seguir, fazemos uma breve introdução ao que se vem chamando de estudos fonológicos, morfológicos e sintáticos sobre línguas de sinais.

Stokoe (1960) apresentou as unidades distintivas como proposta de unidades de nível fonológico. Observemos o sinal ONTEM em Libras;

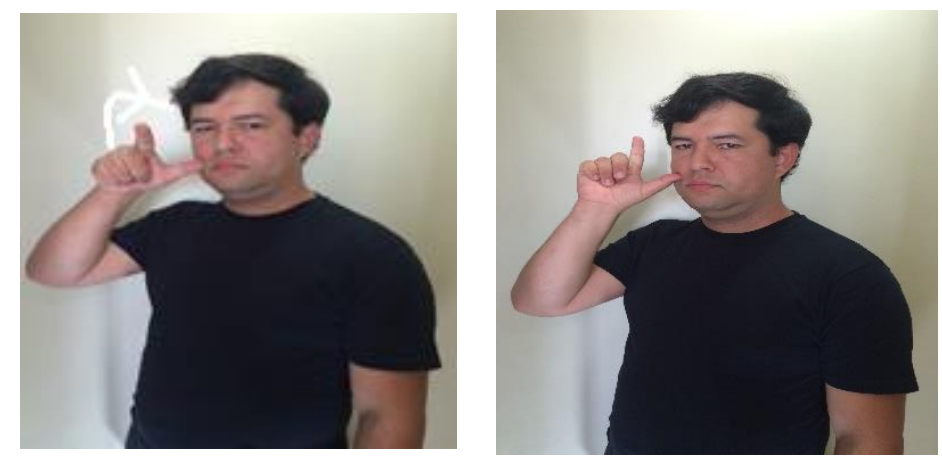

ONTEM

Conforme a imagem anterior, ao associar a configuração de mão em "L"(designation), tocando o polegar, na bochecha (tabula) e realizando o movimento para trás (signation), temos o sinal ONTEM. Esses três aspectos compõem o sinal de acordo com Stokoe (1960).

Battison (1978) apresenta uma proposta de acrescer mais um elemento constituinte do sinal, trata-se da orientação da palma. Anos mais tarde, Klima e Bellugi (1979), dando continuidade aos estudos de Stokoe e Battison, propõem uma nova 
nomenclatura batizada posteriormente como parameters (KLIMA \& BELUGGI, 1979, p. 40), o que tornou ainda mais vivo o status da língua de sinais como língua natural.

Outros pesquisadores, segundo Xavier (2006), consagraram-se ao estudar os parâmetros das línguas de sinais: Padden (1992), Padden e Permutter (1987) e Sandler (1989, 2003) são alguns nomes. Ao pensarmos nos parâmetros, adotaremos na pesquisa a definição apresentada por (COSTA, 2012), de que os parâmetros são entidades visuais que formam significados, assim, devemos ter em mente que eles (os parâmetros) se compõem de:

1) Configuração de Mão (CM);

2) Ponto de Articulação (PA);

3) Movimento (Mov);

4) Orientação da Palma (OP) e

5) Expressões Não-Manuais (ENM).

Observemos como esses constituintes se organizam na execução de um sinal. Aqui o sinal apresentado é “CORAÇÃO DE BEBÊ" (Costa, 2012):

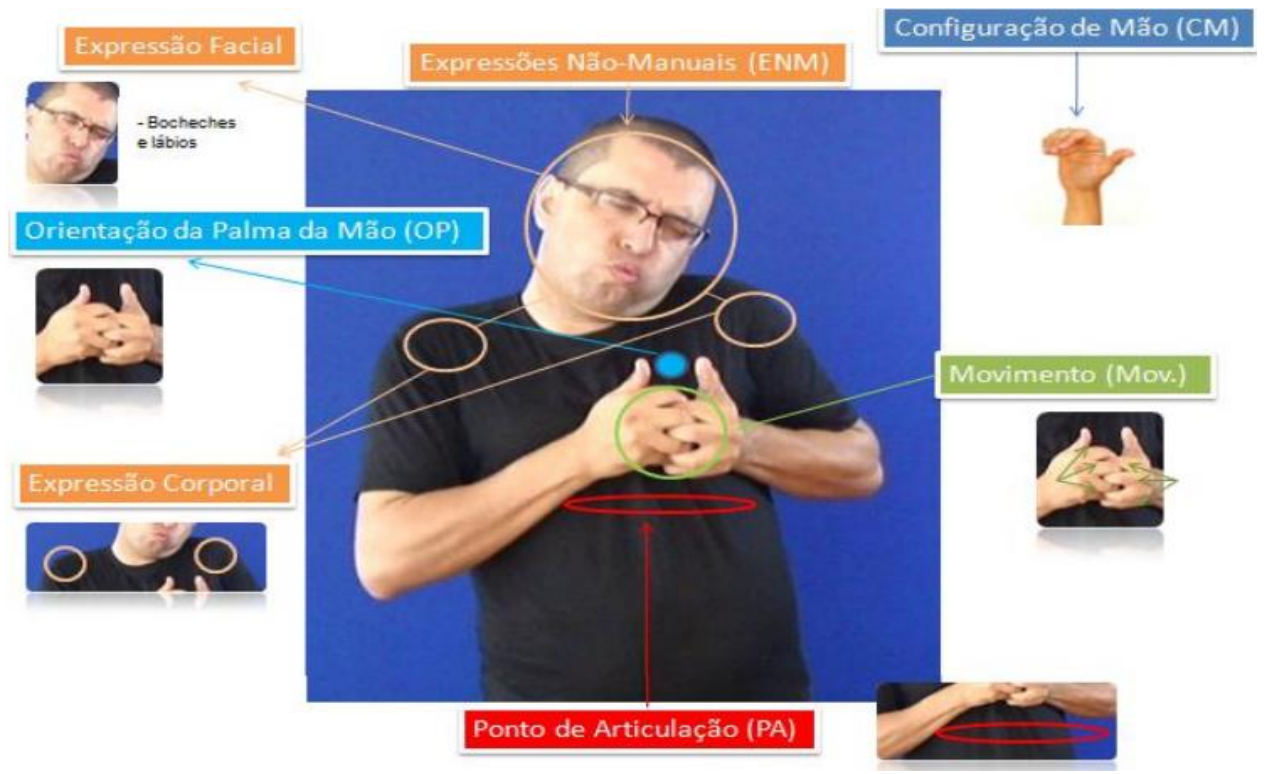

Figura 7: Sinal “CORAÇÂO DE BEBÊ” (COSTA, 2012, p. 37)

É possível observar, na figura, o destaque de cada um dos cinco parâmetros. A configuração de mão corresponde à forma que a mão assume na execução do sinal. A 
Libras tem, segundo Faria-Nascimento (2009), 75 CM. ${ }^{10} \mathrm{O}$ ponto de articulação é o espaço em frente ao corpo ou uma região do próprio corpo onde os sinais são articulados (FERREIRA-BRITO, 2010, p. 37); no sinal "CORAÇÂO DE BEBÊ", o espaço é em frente ao corpo, próximo ao coração. A realização do sinal pede um movimento de abrir e fechar as mãos, simulando o pulsar do coração. A expressão-não-manual, apresentada na literatura, durante muitos anos, como expressão facial, é definida por Ferreira-Brito como um componente não-manual capaz de preencher a função de entonação, como ocorre em línguas orais, Ferreira-Brito (2010, p. 28). Na Fig. 5, a ENM do sinalizante é utilizada para expressar que não se trata de um coração de tamanho qualquer, mas sim, um coração pequeno, um coração de bebê. Segundo ela, o sinal se realiza multidimensionalmente e não linearmente como acontece com as palavras orais, e a sua realização necessita da presença simultânea de seus parâmetros, (FERREIRA-BRITO, 2010, p. 41).

Uma vez observados o que parecem ser os aspectos fonológicos com o sinal “CORAÇÃO DE BEBÊ", vejamos o que a literatura traz como aspectos morfológicos.

Pizzio (2011, p. 29) afirma que

\begin{abstract}
Os estudos linguísticos sobre a Libras são ainda recentes [...] Dentre os aspectos estudados, destacam-se aqueles relacionados com a fonologia e a sintaxe. Poucos são os estudos na área da morfologia e mesmo esses são muito superficiais e baseados nos dados encontrados na língua de sinais americana (ASL), como os apresentados em Quadros e Karnopp (2004). Até o presente momento, não há nenhum trabalho relacionado com morfologia e tipologia linguística, que identifique elementos que distingam as classes de palavras na língua de sinais brasileira.
\end{abstract}

Para Quadros e Karnopp (2004), as justificativas sobre a dificuldade de análise morfológica seriam: i) tradição ancorada nos estudos das línguas orais; ii) a omissão de aspectos que não podem ser investigados em virtude da carência de evidências empíricas e teóricas; iii) as nomenclaturas utilizadas nas línguas orais que eventualmente são objetos de estudo de diversos pesquisadores na busca de universais linguísticos compartilhados entre LOs e LSs e que, em muitas vezes, resultam no engessamento dos dados e evidências obtidas durante análises das línguas sinalizadas.

\footnotetext{
${ }^{10}$ Mas isso varia de autor para autor e não vamos nos ater às diferenças entre eles, pois não interferem em nossa pesquisa.
} 
A presente pesquisa não tem como objetivo provocar a temática dos estudos morfológicos (ou falta deles), apenas fazemos uma reflexão sobre a carência do empirismo necessário para aprofundarmos o assunto. Por ora, consideramos pertinente mencionar que, em consonância com Quadros e Karnopp (2004), Leite (2008) considera a maioria dos sinais em ASL e em Libras como monomorfêmicos, como pode ser observado no sinal CASA:

(5)

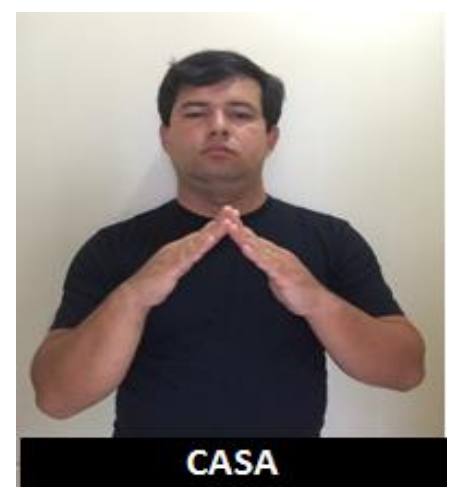

As línguas de sinais, indiscutivelmente, apresentam sinais complexos, porém, estão reduzidos a basicamente três tipos, segundo Leite (2008):

1) Sinais compostos de Liddell (1984) - em que dois sinais são utilizados para a formação de um item lexical. Em Libras:

(6)

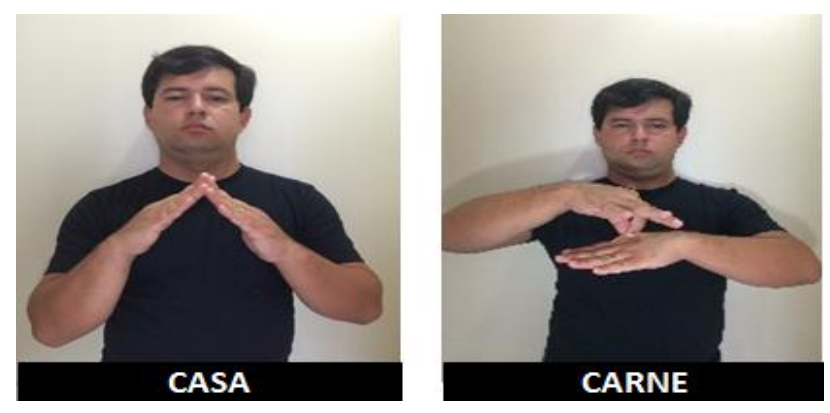

AÇOUGUE 
2) Sinais com incorporação ${ }^{11}$ de número, segundo Frishberg e Gough (1973) ao observarmos o exemplo, é possível perceber que apenas a configuração de mão é alterada, para expressar a quantidade de meses:
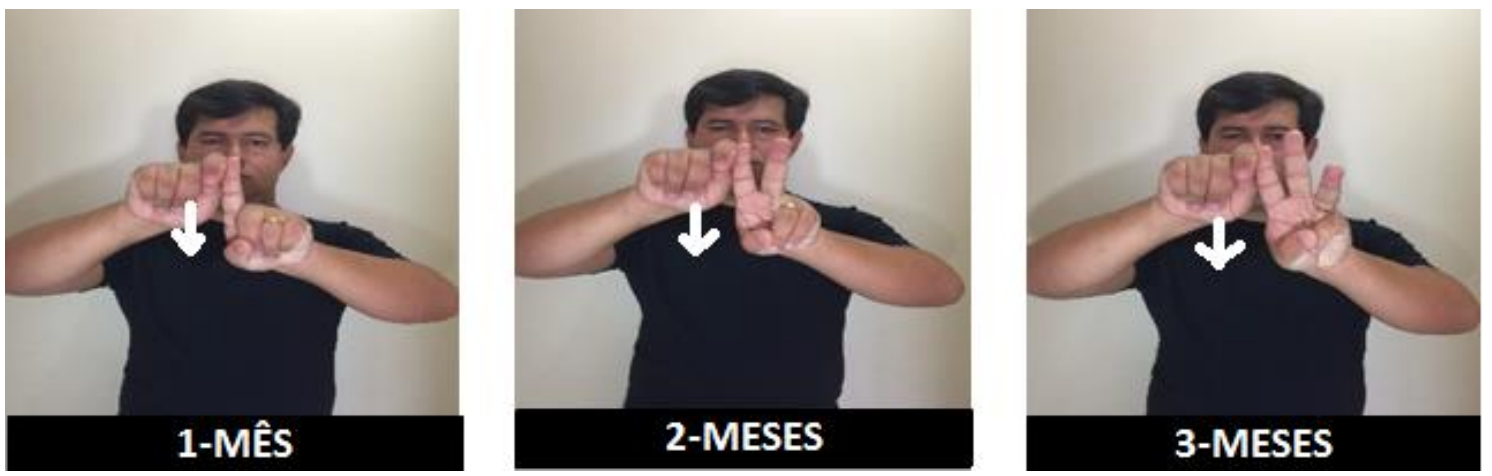

3) E o último tipo de sinais complexos são aqueles modificados aspectualmente, de acordo com Klima e Bellugi (1979), muito utilizados nas línguas de sinais em que a reduplicação das sequências de movimento acompanhadas de expressões não-manuais podem expressar, por exemplo, a ideia de interatividade (LEITE, 2008, p. 27). Como pode ser observado nos sinais de COMER e COMER-MUITO:

(8)
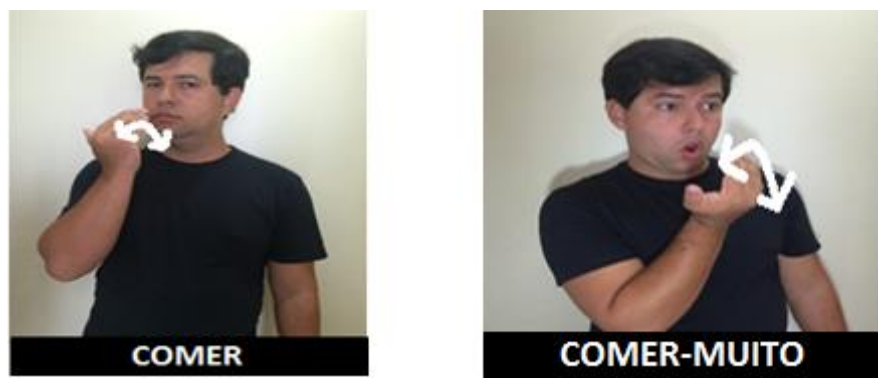

\footnotetext{
${ }^{11}$ Em nossa pesquisa, observamos o emprego generalizado do termo incorporação em sinais que carregam informações sintáticas. Apresentaremos, na seção seguinte, uma breve análise sobre o termo incorporação em Libras.
} 
Já a sintaxe das línguas de sinais passou a ser objeto de pesquisa de muitos estudiosos a partir da década de 1970. Em anos anteriores, os pesquisadores defendiam uma ordem livre das sentenças, uma vez que eram observadas diferentes posições para sujeito e objeto com relação ao verbo. Fisher (1973), Baker (1976), Baker e Padden (1978) e Liddell (1978) foram considerados grandes nomes dos estudos sintáticos ao apresentar, em ASL, expressões-não-manuais como elementos fundamentais na análise de identificação de fenômenos sintáticos. A ordem da ASL, "antes livre e sem restrições" (LEITE, 2008), assume uma nova roupagem menos aleatória cuja ordem básica é a SVO, apesar de apresentar grande variabilidade (QUADROS \& KARNOPP, 2004). O estudo da ordem somado ao importante papel das expressões-não-manuais nas construções das sentenças instigou diversos pesquisadores a desenvolver estudos na área. Retomaremos a esse assunto no capítulo seguinte.

\subsection{Considerações do capítulo}

Neste capítulo, descrevemos a trajetória das línguas de sinais no processo de legitimação como línguas. Fizemos uma breve explanação sobre o que são línguas de sinais bem como os caminhos percorridos para o reconhecimento científico das línguas de sinais, capazes de lhes atribuir o status de língua. Destacamos o pioneirismo dos estudos de Stokoe em 1960. Algumas importantes características linguísticas foram também apresentadas para reiterar o caráter linguístico das línguas de sinais.

No capítulo seguinte, propomos uma revisão na literatura sobre os estudos sintáticos sobre Libras, especialmente de questões pertinentes ao nosso estudo. 


\section{CAPÍTULO 2 - ESTUDOS SOBRE A SINTAXE DA LIBRAS}

\subsection{Introdução}

Este capítulo tem como intuito apresentar os principais estudos sobre a sintaxe da Libras. Ele foi dividido em 4 seções. Na seção 2.1, apresentaremos informações preliminares sobre a sintaxe da Libras. Na seção 2.2, trataremos da ordem dos constituintes, assunto que será amplamente discutido sobretudo em nossa análise de dados. Na seção 2.3, trataremos dos tipos de verbos em Libras, por diferentes autores. Por fim, na seção 2.4 discutiremos o assunto incorporação em Libras.

\subsection{A sintaxe em Libras}

Fernandes (1994) considera sintaxe como a parte da linguística que estuda a estrutura interna das sentenças e a relação interna entre suas partes. Para a autora, ao analisar as estruturas internas das sentenças na Libras, é possível perceber algumas "regras específicas, como a ausência de preposição, de conjunções e de verbos de ligação.”

Quadros e Karnopp, em livro de 2004 sobre Libras, apresentam a sintaxe como o estudo da estrutura da frase, tratando de funções, formas e partes do discurso. A sintaxe, na visão das autoras, trata das funções e das partes do discurso, sendo a parte da linguística responsável por estudar a estrutura interna das sentenças e a relação interna entre suas partes. Assim, seres humanos são capazes de compreender e produzir um número infinito de sentenças. Afirmam ainda que não há uma lista de todas as sentenças possíveis à disposição de cada falante, o que há é uma estrutura que acomoda infinitas combinações de palavras em um número finito de possibilidades.

Seguindo uma perspectiva chomskyana, Quadros e Karnopp (2004) justificam, com base no desempenho (o uso da língua em si), a existência de milhares de línguas diferentes produzidas no mundo. E afirmam, a todo o momento, existir uma mesma competência (o conhecimento para linguagem) para qualquer ser humano. Atribuem a essa competência a possibilidade de julgamentos sobre a formação de sentenças em (a)gramaticais, como, por exemplo, em: 
8) João gosta muito de Maria.

9) *João de muito Maria gosta.

As autoras passam a falar de estrutura sintática envolvendo restrições aplicadas às sentenças para que a mesma seja organizada de uma determinada maneira. Para ilustrar tais afirmações, o exemplo da "ordem” é citado: as línguas apresentam certas restrições que determinam a ordem das palavras em uma sentença. $E$ afirmam que o português e a língua de sinais brasileira têm como ordem básica sujeito-verbo-objeto, SVO.

Trouxemos essa definição de sintaxe para explicitar que tipo de sintaxe se produziu e se produz fortemente no âmbito dos estudos sobre Libras: uma sintaxe da sentença, das estruturas, sem preocupação com a semântica e a pragmática. Essa definição de sintaxe de Quadros e Karnopp (2004) contrasta com a definição de sintaxe que usamos como pano de fundo de nossas análises. Para nossa pesquisa, a sintaxe é a responsável pelo estudo da disposição das palavras na frase e das frases no discurso, incluindo a sua relação, entre as múltiplas combinações possíveis, para transmitir um significado completo e compreensível. Para Givón (1970), a sintaxe é uma entidade dependente, funcionalmente motivada por processos comunicativos e cognitivos, o que leva a pragmática do discurso a desempenhar um papel decisivo na explicação da sintaxe. A sintaxe é, portanto, a codificação de dois domínios funcionais distintos: a semântica e a pragmática, o que nos leva a pensar que as expressões linguísticas não são pensadas como objetos isolados, mas como instrumentos que são usados pelo falante para evocar na mente do ouvinte uma dada interpretação desejada e intervir direta ou indiretamente em seu comportamento.

A seguir, apresentamos o que se discute sobre a ordem de palavras em Libras.

\subsection{Ordem dos constituintes em Libras}

Os termos ordem básica, canônica ou subjacente são amplamente utilizados nos estudos da descrição de diferentes ordens das línguas. Segundo Quadros e Karnopp (2004), os termos mencionados anteriormente são observados desde estudos tipológicos aos estudos formais. As autoras também afirmam que "básica" e "canônica" são termos 
relacionados à ordem de superfície. Enquanto "subjacente" relaciona-se à estrutura profunda das frases. Essa é uma nítida referência aos princípios gerativos.

Para as autoras, Libras apresenta uma ordenação mais básica que as demais:

\begin{abstract}
A ordem Sujeito-Verbo-Objeto é mais básica e são os tipos de construção mais apresentados na língua de sinais brasileira. Exemplos que utilizam a construção SVO são sempre considerados gramaticais. (QUADROS E KARNOPP, 2004 p.140)
\end{abstract}

Teria sido essa generalização sobre Libras baseada em estudos sobre a Língua de Sinais Americana (ASL)? Pesquisadores de ASL postularam a ordem básica como Sujeito-Verbo-Objeto. Sobre essa ordem em ASL, Fisher (1973, p. 15) afirmou que "se o verbo for transitivo e o sujeito ou o objeto forem reversíveis (isto é, poderiam ser o sujeito ou o objeto e ainda ser semanticamente plausíveis), as ordens permissíveis são mais restritas $(\ldots) "$.

Sobre o assunto em Libras, Quadros, Pizzio e Rezende (2009, p. 16) fazem uso de glosas (não há ilustrações ou imagens em Libras) para exemplificar as categorias de sujeito e objeto reversíveis ${ }^{12}$ :

A. Sentenças com argumentos reversíveis

JOÃO GOSTA MARIA

MARIA GOSTA JOÃO

B. Sentenças com argumentos não-reversíveis

JOÃO COMPRAR CARRO

*CARRO COMPRAR JOÃO

Outra observação interessante é que, na obra, algumas glosas que aparecem em português são oriundas do inglês, as autoras fazem a referência e apresentam os exemplos,

12 As autoras consideram como categorias de sujeito e objeto reversíveis quando sujeito e objeto são nomes próprios e apresentam a mesma escala de agentividade; assim, os dois argumentos podem exercer a função sintática de sujeito ou objeto da sentença. Sobre o assunto, ler Quadros e Karnopp (2004). 
em inglês, entre parênteses, ou seja, a língua de sinais americana foi traduzida para o inglês e posteriormente para o português, para que então fosse ilustrado em Libras.
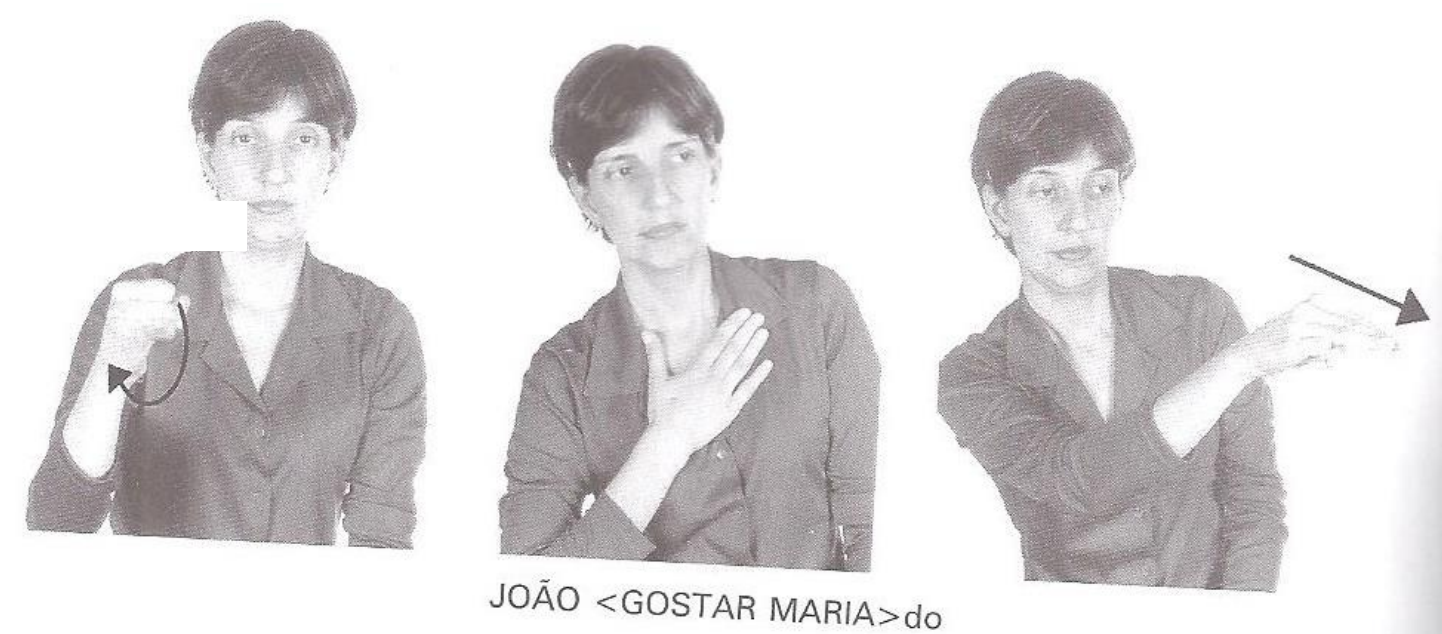

Figura 8: Sentença com argumentos reversíveis (QUADROS e KARNOPP, 2004, p. 159)

Segundo Fisher (1973) apud Quadros e Karnopp (2004), a ordem básica em ASL é SVO. As autoras, apesar de considerarem a mesma ordem básica, para Libras (SVO), reconhecem a flexibilidade em outras possíveis combinações OSV, VOS e SOV e, ressaltam sobre a topicalização de objeto em sentenças OSV.

Observemos alguns exemplos:

(9)
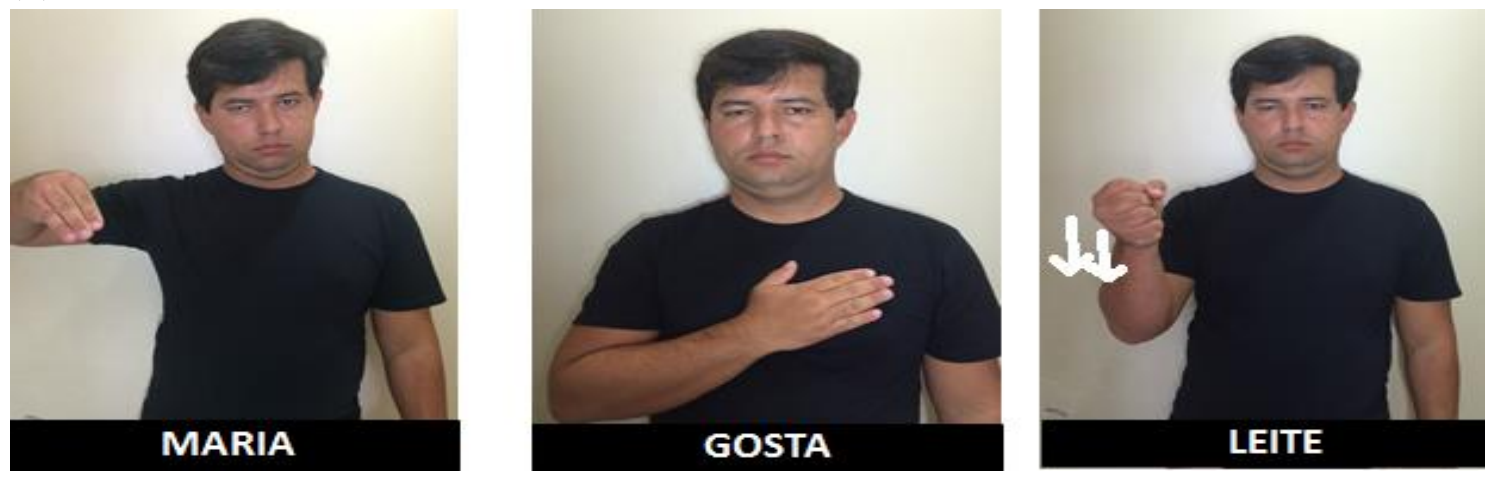

Maria gosta de leite. 
(10)
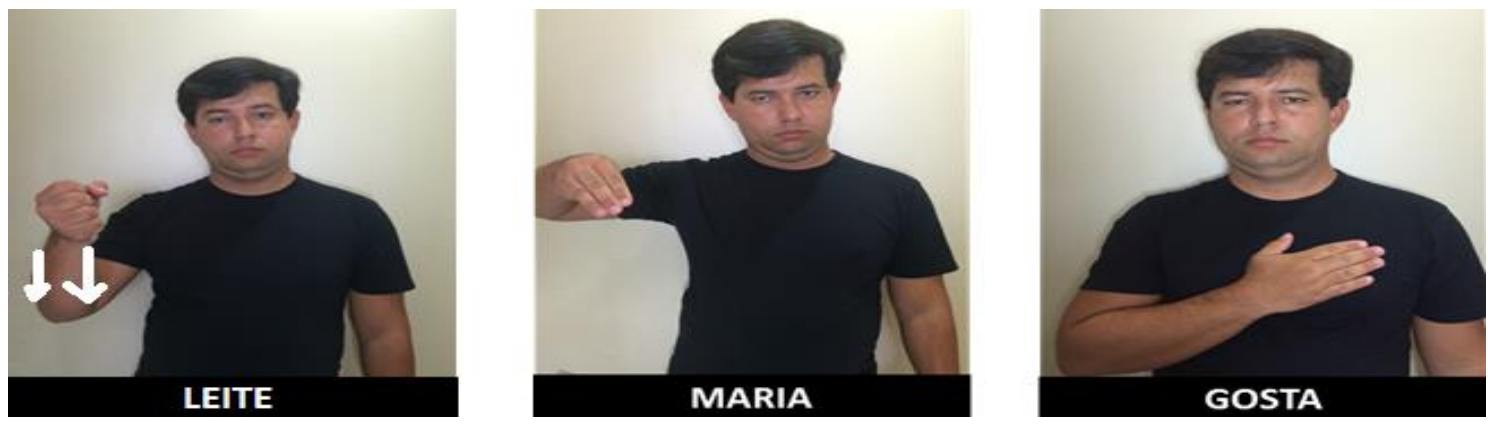

Leite, Maria gosta.

Apesar de expressar o mesmo conteúdo semântico, os dois enunciados apresentam diferentes combinações sintáticas dos constituintes. Em (9), a ordem é SVO, considerada básica e mais frequente na Libras, segundo Quadros e Karnopp (2004). Em (10), a ordem OSV é observada como mais natural entre os surdos, conforme será apresentado no capítulo referente a análise de dados. A topicalização na sentença (10) é possível por apresentar argumentos que não são reversíveis, diferentemente do enunciado da Figura 8 (João gosta da Maria)

Quadros e Karnopp (2004) consideram que a sentença, ao trazer verbos simples, aqueles sem concordância (assunto de nossa próxima seção) ao apresentar verbos reversíveis necessita ordenar os constituintes em SVO, afinal, os argumentos possuem propriedades semânticas capazes de exercer tanto a função sintática de sujeito quanto de objeto. Ao tentar, por exemplo, topicalizar o enunciado da Figura 8 "João gosta da Maria”, teríamos uma sentença agramatical. Particularmente nessa sentença, a topicalização não é uma possibilidade em Libras, para as autoras. Observaremos situação semelhantes no capítulo de análise dos dados.

A topicalização, processo para identificar explicitamente um tópico, é um recurso bastante frequente em Libras. Para Quadros e Karnopp (2004, p. 148),

A ordem de algumas construções é alterada pela presença do tópico. O tópico é o tema do discurso que apresenta uma ênfase especial posicionado no início da frase e seguido de comentários a respeito desse tema. Esse recurso gramatical é muito comum na língua de sinais brasileira.

Para as pesquisadoras, uma sentença topicalizada, é constituída com alteração da ordem básica da Libras SVO, apresenta o tópico com ênfase especial e posição de 
destaque, no início da frase e principalmente, com a presença de expressões-não-manuais. Entretanto, nossos dados não revelaram a topicalização associada a marcas não-manuais, (retomaremos o assunto no capítulo 5 - análise dos dados)

Por fim, a obra de Quadros e Karnopp (2004) destaca ainda as construções com foco:

\begin{abstract}
As construções com foco são aquelas que apresentam constituintes duplicados dentro da mesma oração. Essas "cópias" ocorrem quando o constituinte é enfatizado, mas de forma diferente da ênfase dada aos tópicos [...] O foco é gerado quando há uma informação interpretada com entonação mais marcada, ou seja, focalizada. (QUADROS e KARNOPP, 2004, P. 152)
\end{abstract}

Embora, não haja uma explicação na obra de como diferir a ênfase do tópico para a ênfase do foco, é possível perceber o foco nos elementos duplicados, como no exemplo apresentado pelas autoras:
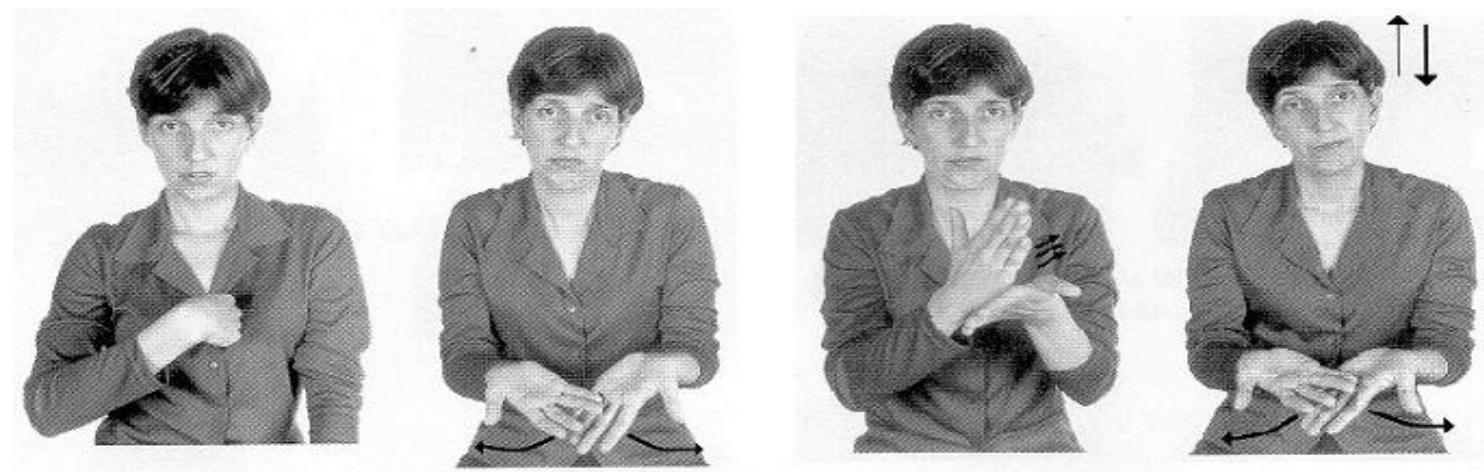

Figura 9: EU PERDER LIVRO PERDER (QUADROS e KARNOPP, 2004, p. 152)

Essa "cópia" de alguns constituintes da sentença, trazida pela literatura como elementos duplicados (QUADROS e KARNOPP, 2004, p. 150) é muito observada nas construções da Libras, como também revelam nossos dados. Na figura 9, é possível perceber a cópia (ou duplicação) do verbo perder, elemento focalizado na sentença.

Outra possibilidade de ordem é a VOS que, para Quadros e Karnopp (2004), ocorre sobretudo em contextos de foco contrastivo, como em: 
(11)
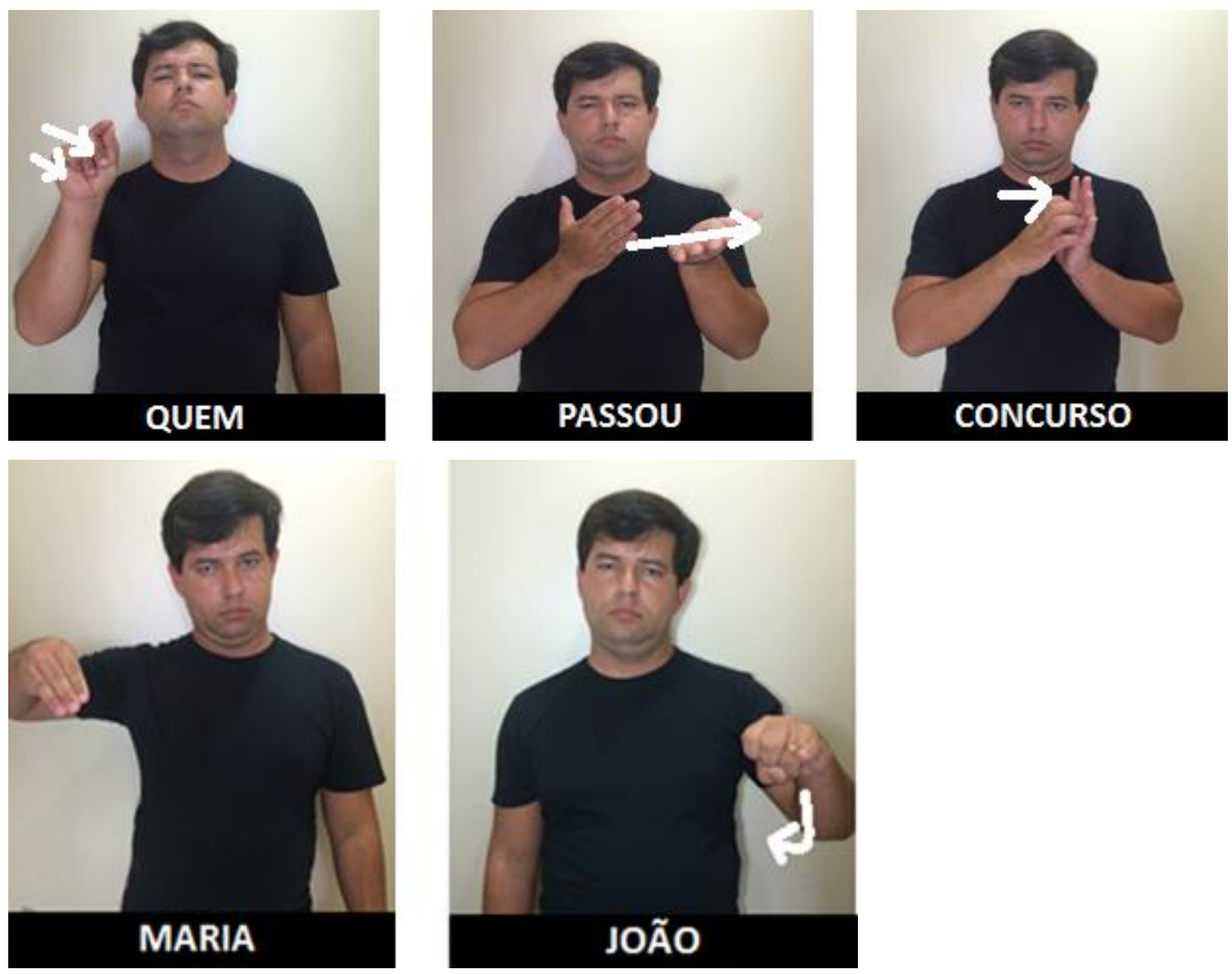

"Quem passou no concurso Maria ou João?"

(12)
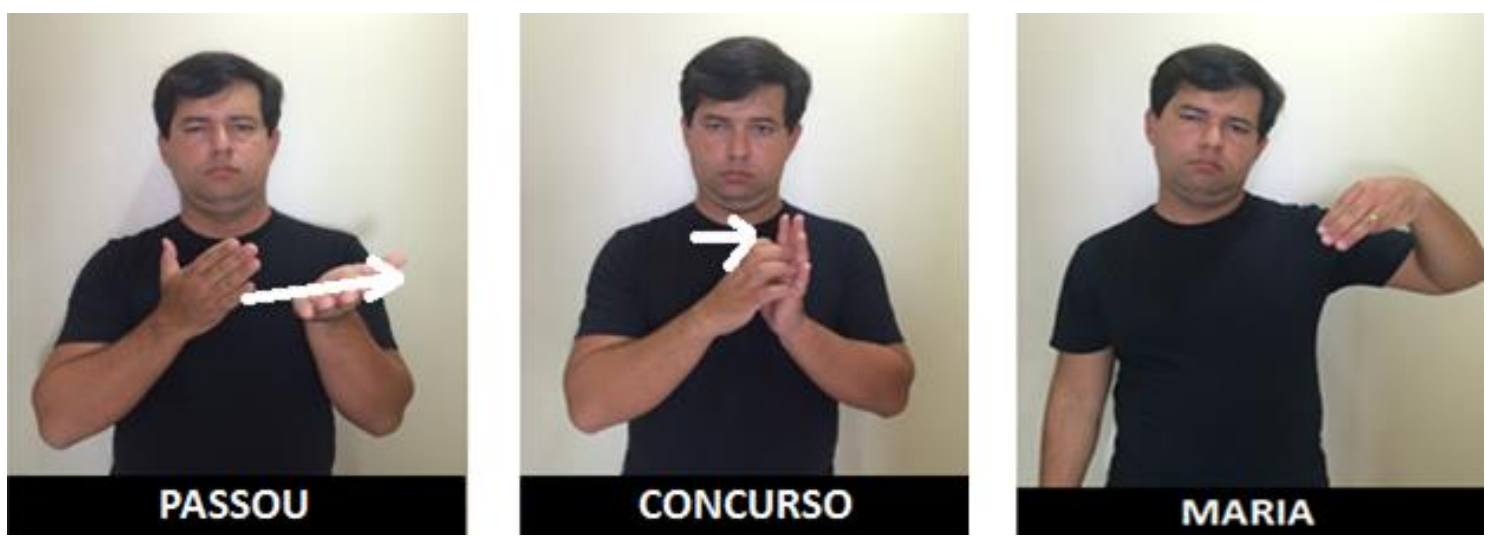

"Passou no concurso Maria"

Maria é apresentada como foco. 
A ordem SVO seria de fato a ordem básica da língua brasileira de sinais? Ou a influência de estudos sobre o português ou demais línguas orais e outras línguas de sinais levou a essa afirmação? Importante ressaltar que esses estudos não apresentam pesquisa etnográfica ou amostragem. Quem seriam os colaboradores que contribuíram para que se chegasse à tal conclusão? Porém, o objetivo aqui não é comprovar qual a ordem ou como se dá a construção de frases em Libras, mas sim fazer uma reflexão sobre o que vem sendo postulado pela literatura sobre a sintaxe em Libras. Cada vez mais, percebe-se a necessidade de revisarmos as perspectivas da sintaxe da Libras com novas pesquisas, novas observações e principalmente novas coletas de dados a partir de registros interativos e comunicativos.

Para compreender um pouco mais sobre a ordem em Libras, é relevante perceber a importância do verbo na sentença. A forma como a Libras o categoriza é algo merecedor de destaque, assim, dedicaremos a próxima seção para apresentar um estudo sobre os verbos em Libras.

\subsection{Tipos de verbos em Libras}

Em consonância com Ferreira-Brito (2010), Strobel \& Fernades (1998, p. 54) classificam os verbos em: direcionais e não-direcionais. Os verbos direcionais são aqueles que possuem marca de concordância. Para as pesquisadoras, a direção do movimento marca, no ponto inicial, o sujeito e, no ponto final, o objeto, como pode ser observado em:

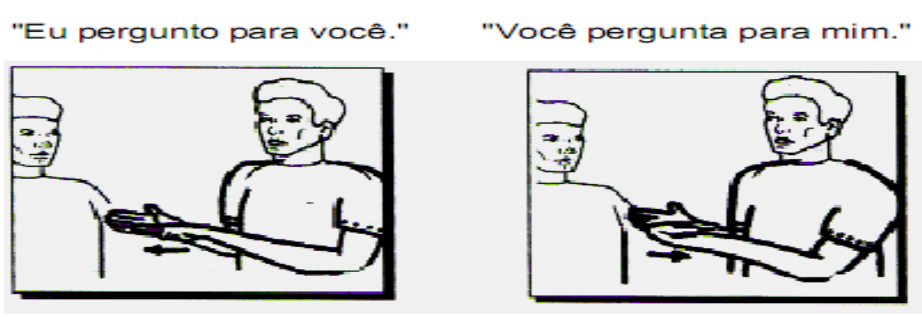

"Eu aviso voce.."

"Você me avisa."
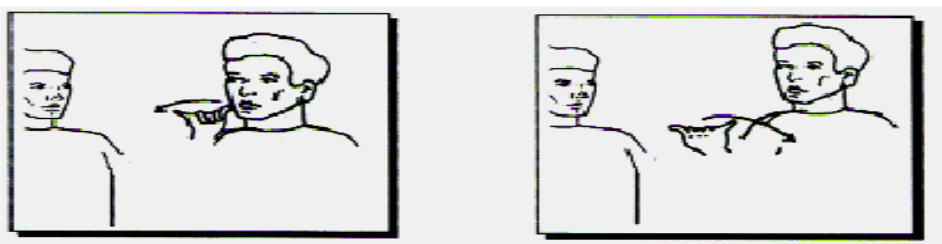

Figura 10: Verbos direcionais (STROBEL \& FERNANDES, 1998, p. 55) 
Já os verbos chamados verbos não-direcionais seriam aqueles que não possuem a marca de concordância. Quando se faz uma frase, é como se eles ficassem na "forma infinitiva". Os verbos não-direcionais aparecem em duas subclasses:

\begin{abstract}
Aqueles que são ancorados no corpo: são verbos realizados com contato muito próximo do corpo. Podem ser verbos de estado cognitivo, emotivo ou experienciais, como: pensar, entender, gostar, duvidar, odiar, saber; e verbos de ação, como: conversar, pagar, falar. E a segunda subcategoria, a dos verbos que incorporam o objeto: quando o verbo incorpora o objeto, alguns parâmetros modificam-se para especificar as informações. (STROBEL \& FERNANDES, 1997, p. 23)
\end{abstract}

Exemplo:

COMER

COMER-MAÇÃ

COMER-BOLACHA

COMER-PIPOCA

CORTAR

CORTAR-CABELO

CORTAR-UNHA

CORTAR-FACA

Na obra, Strobel \& Fernandes (1998) apresentam apenas algumas listas de exemplos de verbos que incorporam objetos, para exemplificar, inserimos as seguintes imagens: 

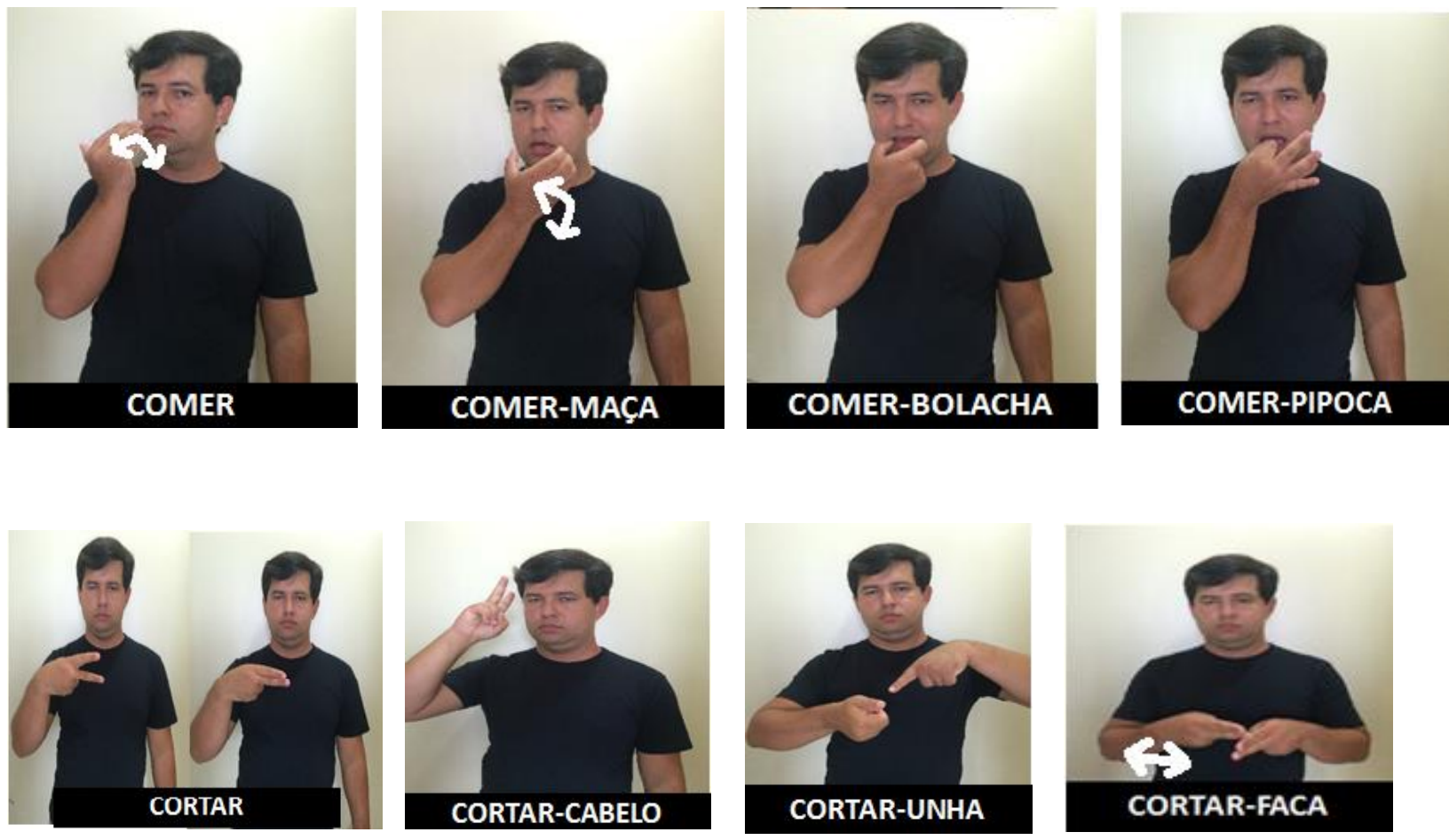

Ao afirmar que os verbos não direcionais permanecem como no infinitivo, estamos falando de qual língua? Libras ou língua portuguesa? A ausência da ilustração dos exemplos torna a obra um tanto confusa. Parte-se do princípio que o leitor conhece os exemplos de memória e não se usam imagens. Optamos pelo recurso de inserção das imagens, visando tornar a leitura mais didática, sobretudo para o leitor que não conhece a Libras.

Posterior a estes estudos, anos mais tarde, Quadros e Karnopp, (2004, p. 116) falam em "comportamento dos verbos", e o que antes era apresentado na literatura como verbos direcionais e não-direcionais são agora categorizados em verbos simples, verbos com concordância ou verbos espaciais.

\subsubsection{Verbos simples}


Os verbos simples são aqueles que, além de não apresentar concordância, não incorporam afixos locativos ${ }^{13}$. Como pode ser observado em ${ }^{14}$ :
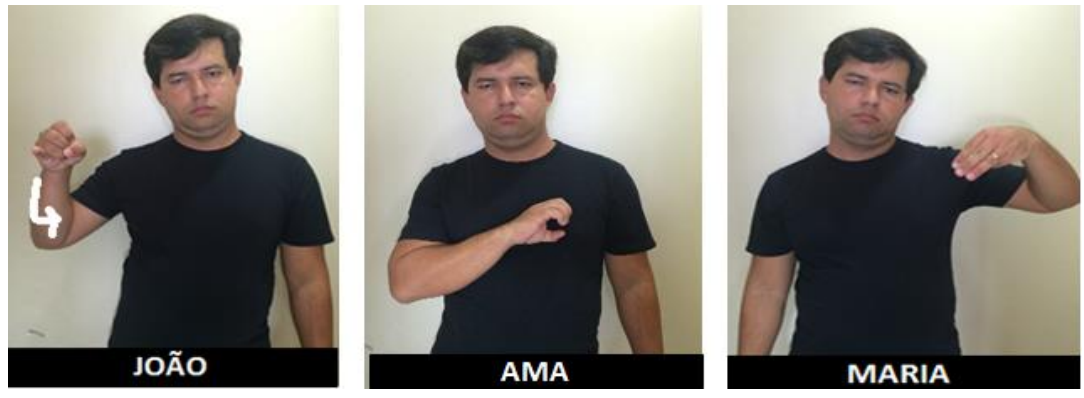

“João ama Maria."

(15)
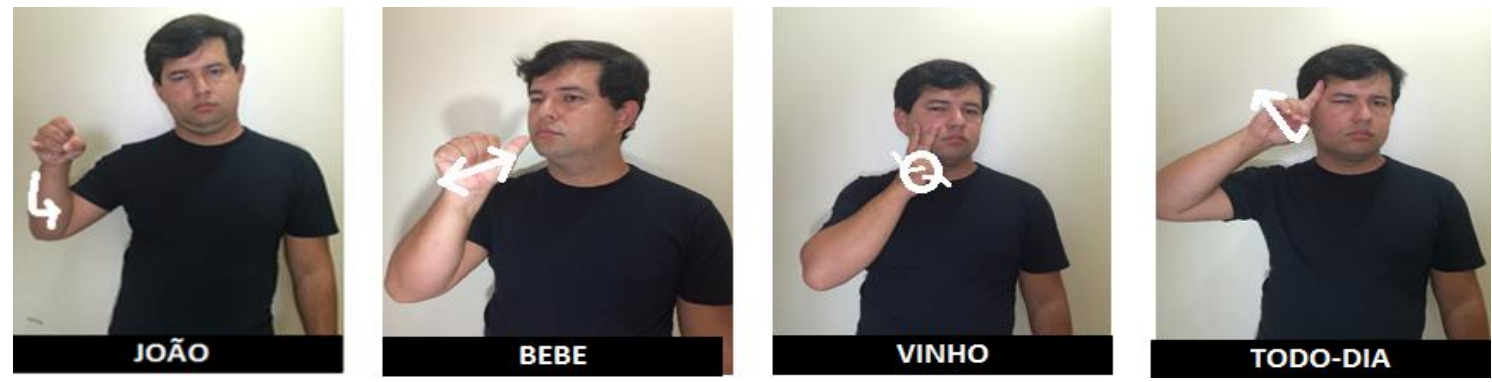

"João bebe vinho todos os dias."

\subsubsection{Verbos com concordância}

Os verbos com concordância são os verbos que apresentam marca de concordância e, segundo Quadros e Karnopp (2004, p. 117), são verbos que se flexionam em pessoa, número e aspecto, mas não incorporam afixos locativos. É muito comum encontrarmos na literatura de pesquisas em Libras essa concordância relacionada à

\footnotetext{
${ }^{13}$ Apesar de entendermos que o termo incorporação de afixo locativo é inadequado a esse contexto, manteremos o termo por ser amplamente divulgado na literatura sobre Libras. Retomaremos o assunto nas próximas seções.

${ }^{14}$ Ao escanear as imagens originais do livro, para apresentar os exemplos, todas em preto e branco, a visualização torna-se prejudicada pela falta de qualidade, e, por este motivo, optamos por reproduzir as imagens com as fotos.
} 
incorporação de sujeito e objeto, em contextos em que o sujeito e o objeto fazem parte do próprio verbo. Sobre incorporação, falaremos na seção seguinte.

São exemplos de verbos com concordância:

$(16.1)$
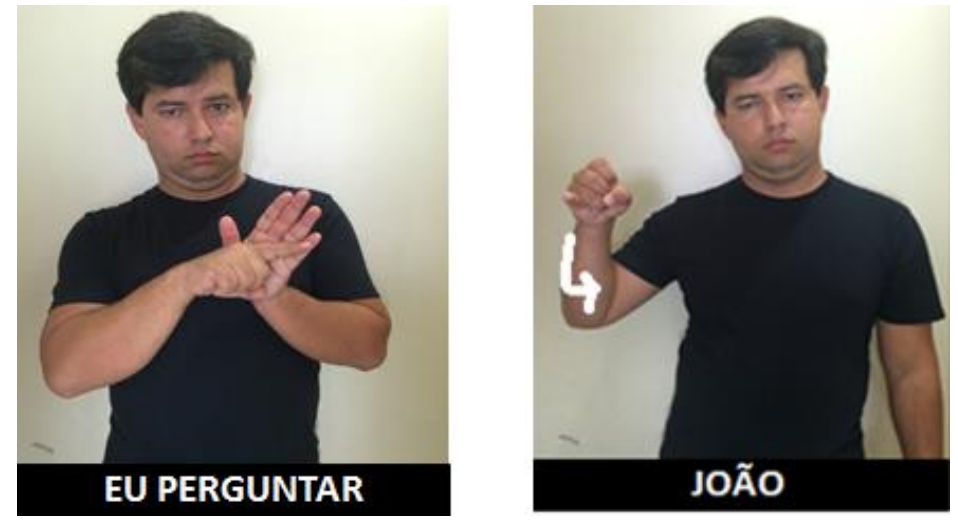

"Eu pergunto ao João."

$(16.2)$
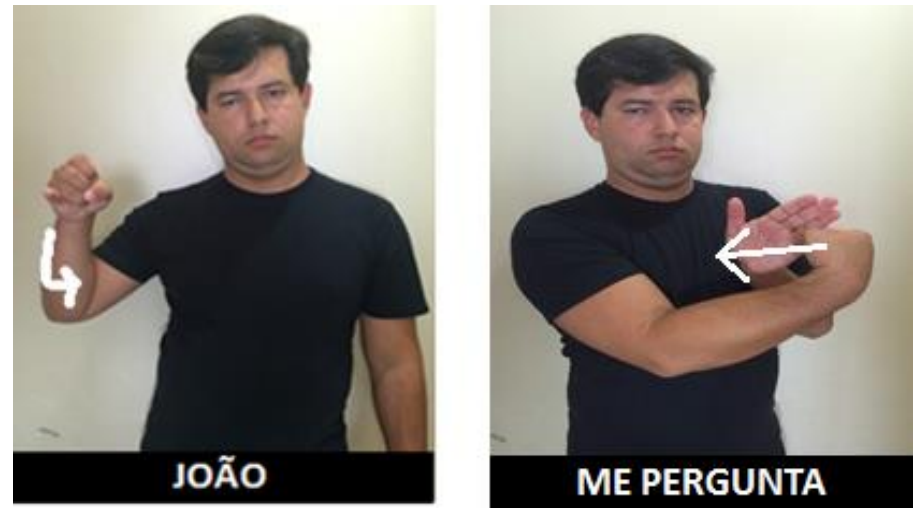

"João me pergunta."

$(17.1)$
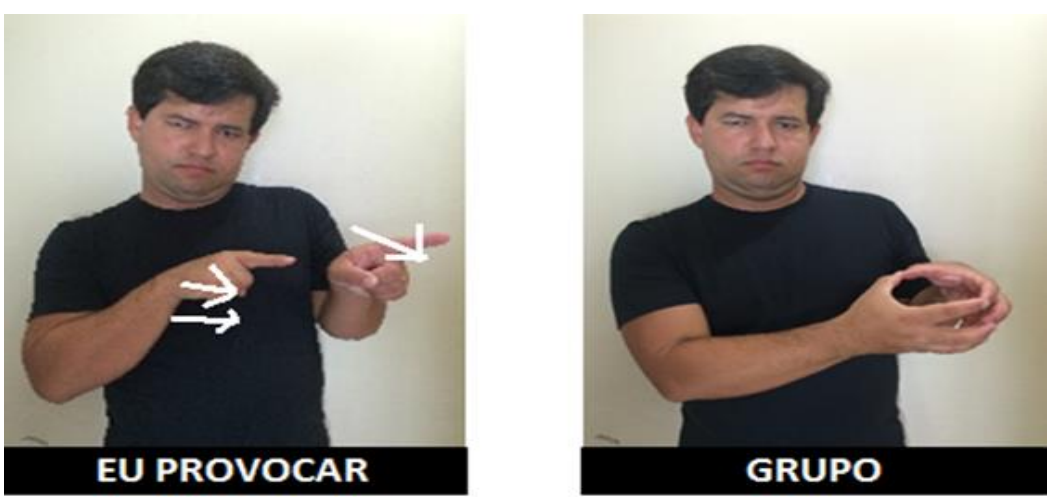

“Eu provoco o grupo." 
$(17.2)$

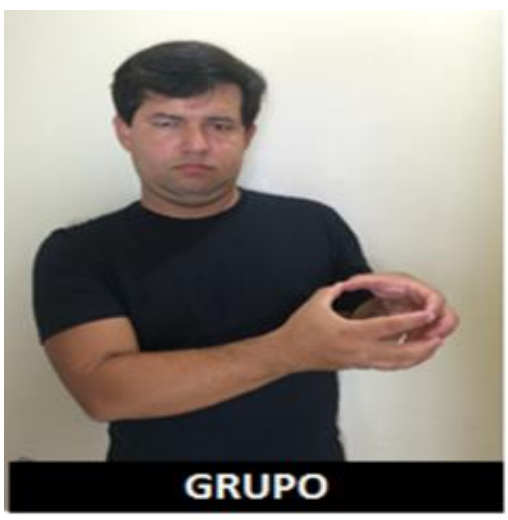

"O grupo me provoca."

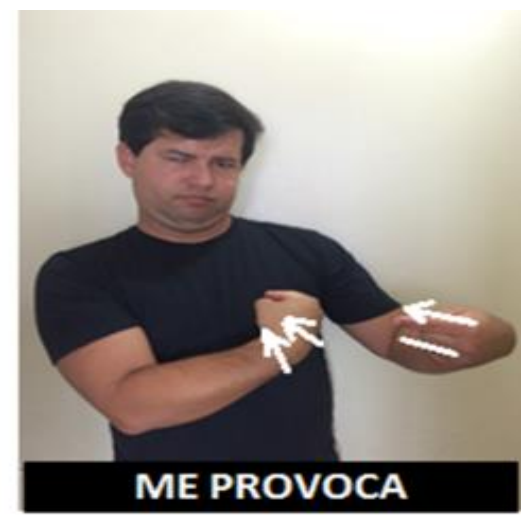

ME PROVOCA

É possível perceber que, por meio da orientação das mãos, o ponto de partida e o ponto de chegada são marcados nos verbos, expressando respectivamente sujeito e objeto.

Como também ocorre com o verbo AVISAR:

(18)

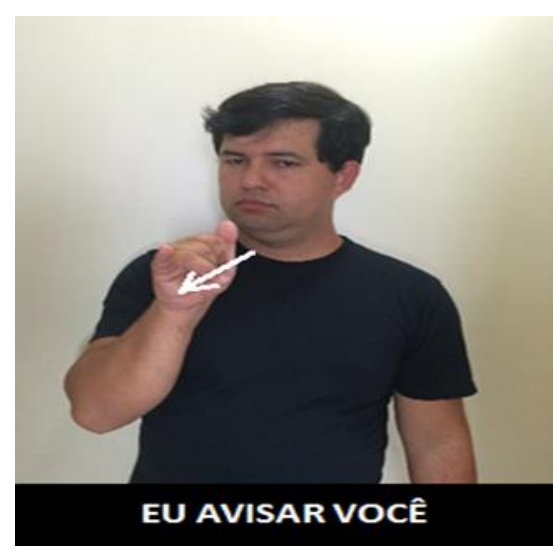

"Eu avisei você."

Também como exemplo de verbos de concordância, porém pertencentes a uma categoria distinta, são os intitulados por Quadros e Karnopp (2004) como backward verbs. Nessa categoria, a trajetória para a realização do sinal verbal é iniciada na posição de objeto e vem em direção ao sujeito, onde é concluída (na posição de sujeito), ao contrário dos demais verbos com concordância, que começam sua trajetória na posição do sujeito e vão em direção à posição do objeto. Como ocorre com o verbo CONVIDAR: 
(19)

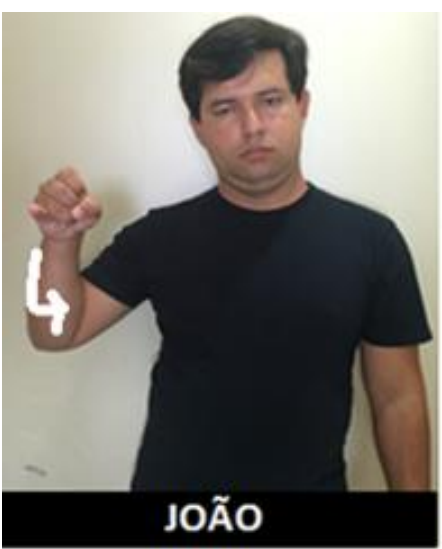

"João convidou Maria."
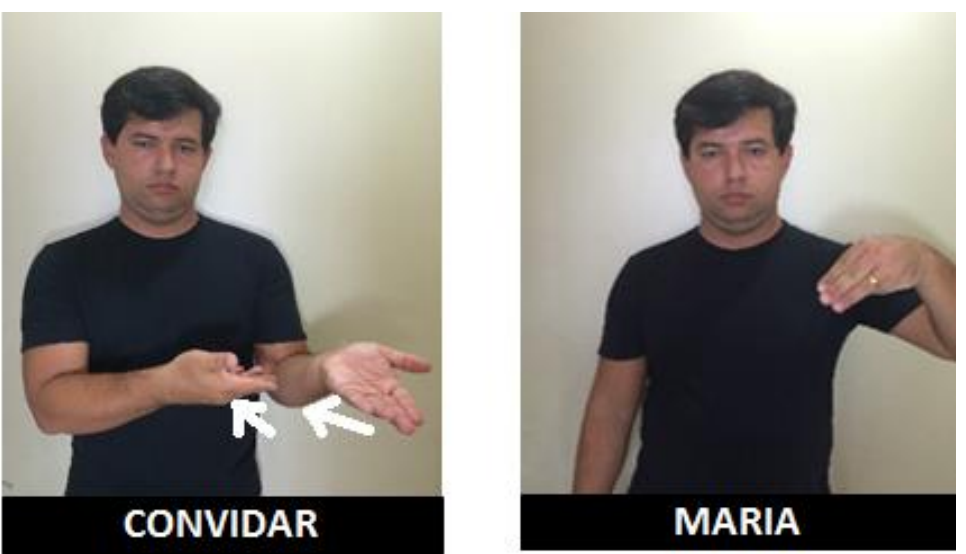

\subsubsection{Verbos espaciais}

Os verbos espaciais são verbos que têm os chamados afixos locativos. De acordo com Crato (2010, p. 30), esses verbos apresentam um ponto de partida (sujeito que faz a ação) e um ponto de chegada (local), como ocorre com os exemplos:

(20)
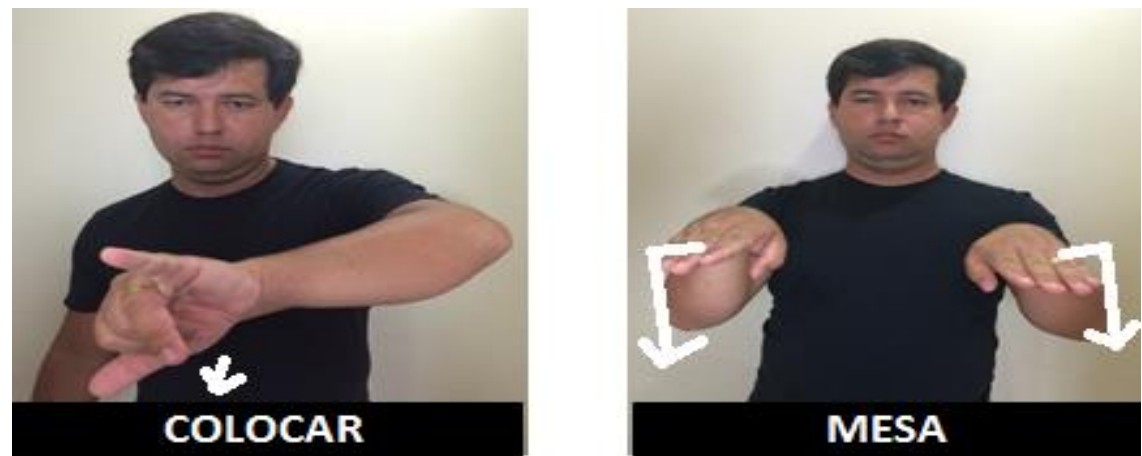

"Colocou na mesa." 

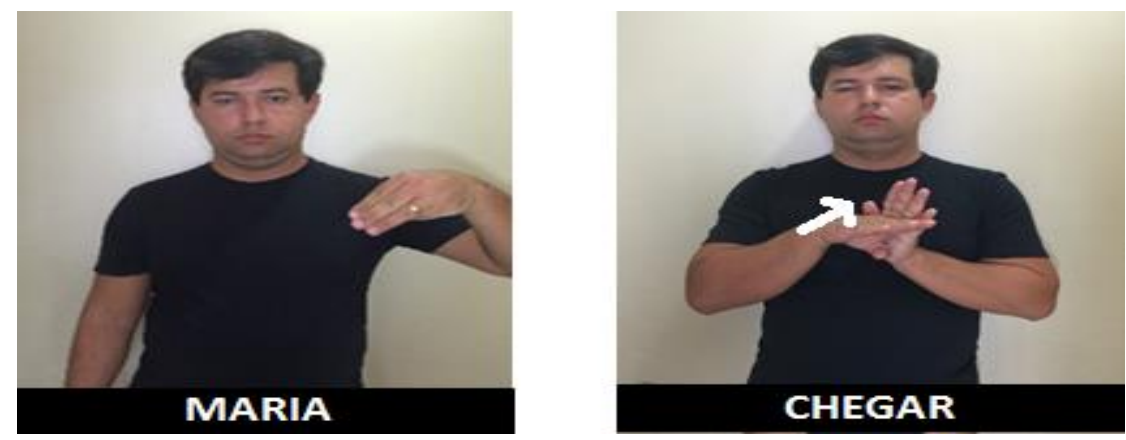

2. "Maria chegou."

Ao observar os tipos de verbos na Libras, contrastando a proposta de Strobel \& Fernandes (1998) com a proposta de Quadros e Karnopp (2004), é possível perceber diferentes abordagens e explicações para a categorização dos verbos. Por exemplo, Strobel \& Fernandes (1998), apesar de classificarem os verbos em somente duas classes (direcionais e não-direcionais,) subclassificam os verbos não direcionais em mais dois grupos: os verbos ancorados no corpo (verbos com contato muito próximo do corpo) e os verbos que incorporam o objeto (aqueles que, segundo as autoras, "modificam-se para especificar informações" (Strobel \& Fernandes 1998, p. 23). Diferentemente, Quadros e Karnopp (2004) classificam-nos em três grupos: simples, com concordância e espacial.

Outros pesquisadores apresentam, ainda, outras propostas de classificação e subclassificações dos tipos verbais, observando, por exemplo, "importantes fenômenos de análise" (LIDELL, 2003 apud LEITE, 2008, p. 40), como nos verbos indicadores e nos verbos descritivos. Os verbos indicadores são os verbos chamados de flexão.Encontramos, na literatura de pesquisas em Libras, divergências, por exemplo, no que diz respeito à flexão nos verbos. Alguns pesquisadores afirmam que existem verbos com flexão e verbos sem flexão, como Strobel \& Fernandes (1998), Quadros e Karnopp (2004), Lidell (2003). Um dos elementos definidores de flexão é ela ser sistemática e abranger o máximo possível de itens de uma dada classe. Logo, estabelecer que, em Libras, haveria verbos com flexão e verbos sem flexão é estranho ao próprio conceito de flexão.

Para Meir (1998, apud QUADROS e QUER 2010, p. 5), os verbos apresentam dois distintos tipos de concordância: uma concordância semântica, realizada pela trajetória verbal; e uma concordância sintática, realizada pela orientação da palma da 
mão, o que os subclassificariam. Esses podem ser excelentes temas de pesquisas em Libras; porém, como não constituem objeto da presente pesquisa, não nos ateremos a essa discussão.

\subsection{Incorporação em Libras?}

É bastante comum encontrar, na literatura das línguas de sinais, análises que defendem a existência de processos morfológicos de flexão e derivação.

Nas línguas de sinais, podemos encontrar vários processos morfológicos, tanto flexionais como derivacionais [...] Em relação à língua de sinais brasileira, há vários aspectos da morfologia que ainda não foram estudados. Quadros e Karnopp (2004) apresentam uma revisão de alguns estudos realizados com a língua de sinais americana e apresentam algumas possíveis aplicações à língua de sinais brasileira (QUADROS, PIZZIO e REZENDE, 2009, p. 31)

Mas as análises morfológicas não esclarecem, por exemplo, alguns processos. Para Quadros e Karnopp (2004), no estudo da morfologia das línguas de sinais e em especial, da Libras, é preciso estar atento à

Tradição decorrente do estudo das línguas orais - A primeira dificuldade ao se tentar descrever e explicar a morfologia da língua de sinais brasileira é o peso da tradição, que dificulta a revisão e a adoção de novas posições. A questão é: realizar um estudo da morfologia a partir da análise da morfologia das línguas orais ou reduzir-se ao estudo da morfologia das línguas de sinais? Ao optar-se pela primeira, pode-se desconsiderar as especificidades das línguas de sinais, quanto à sua modalidade de percepção e produção. Ao optar-se pela segunda, depara-se com uma bibliografia reduzida e limitada, principalmente ao estudo da língua de sinais americana. Além disso, na língua de sinais brasileira, raros são os estudos linguísticos realizados nesta área. (QUADROS e KARNOPP, 2004, p. 86)

Ao observar o processo intitulado como incorporação em Libras nas mais diversas pesquisas, é possível afirmar que esse termo carece de especificação, pormenorização. Observemos como algumas autoras apresentam a incorporação em Libras. 
Para Ferreira-Brito (2010, p. 52), “a incorporação de informação morfossintática se dá pela duplicação da informação lexical somada à informação de ordem sintática (objeto direto, locativo, sujeito)". Como nos exemplos abaixo ${ }^{15}$ :
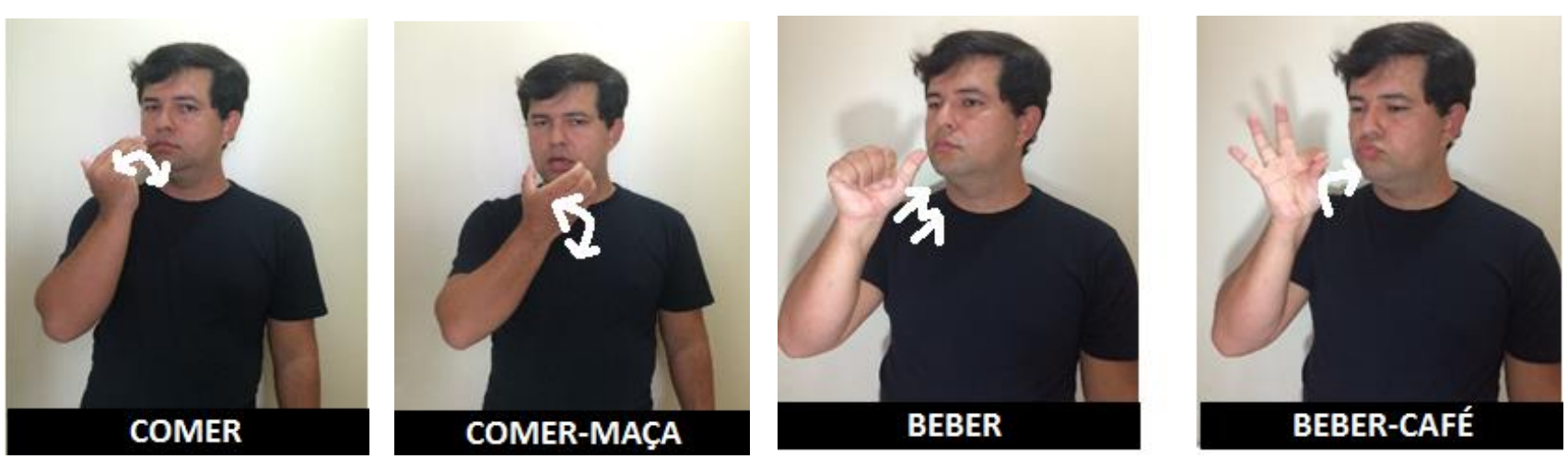

Na imagem (22), são apresentados os sinais COMER e COMER-MAÇÃ, em que a autora considera que o objeto direto foi incorporado ao verbo. Nos sinais BEBER e BEBER-CAFÉ a nova configuração de mão também evidencia o objeto incorporado, (FERREIRA-BRITO 2010, p. 54).

Felipe (2006) considera que novos sinais podem ser criados em Libras, a partir de processos de derivação. Para a autora, os processos de incorporação de um argumento, numeral ou negação, são exemplos de tais processos. São exemplos de incorporação de numeral:
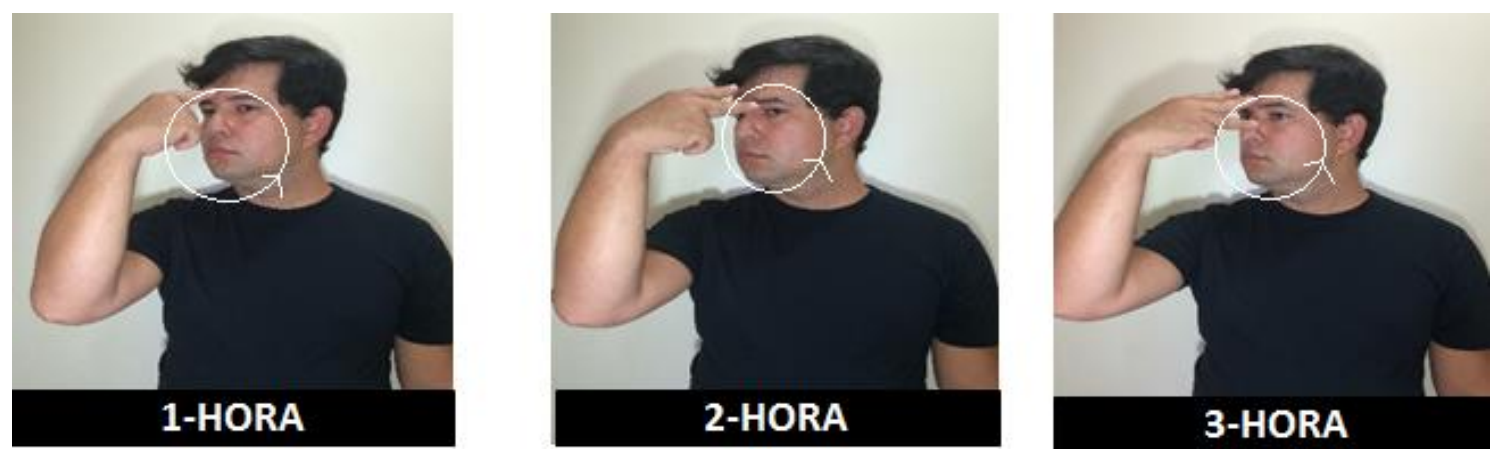

\footnotetext{
15 Os exemplos são retirados de Ferreira-Brito (2010, p. 53-54), mas foram refeitos em virtude da qualidade das imagens.
} 
Por que não chamar esses sinais de sinais compostos? Por que usar o termo incorporação? Que vantagens esse termo traz para os estudos em tela? Essas e outras perguntas podem ser feitas e não encontram respostas nos estudos sobre o assunto.

Quadros e Karnopp (2004 p.110), em consonância com as outras pesquisadoras, falam em incorporação de negação, como "outro processo produtivo na língua de sinais brasileira”. Acerca da incorporação da negação, as autoras afirmam que:

Através de vários processos o item a ser negado sofre alteração em um dos parâmetros, especialmente o parâmetro do movimento, acarretando, assim, no aparecimento de um item de estrutura 'fonético-fonológico' diferente daquele que é a sua base, ou seja, no aparecimento de sua contraparte negativa (QUADROS e KARNOPP 2004, p. 110)

Essa incorporação de negação, para as pesquisadoras, pode ser observada em:
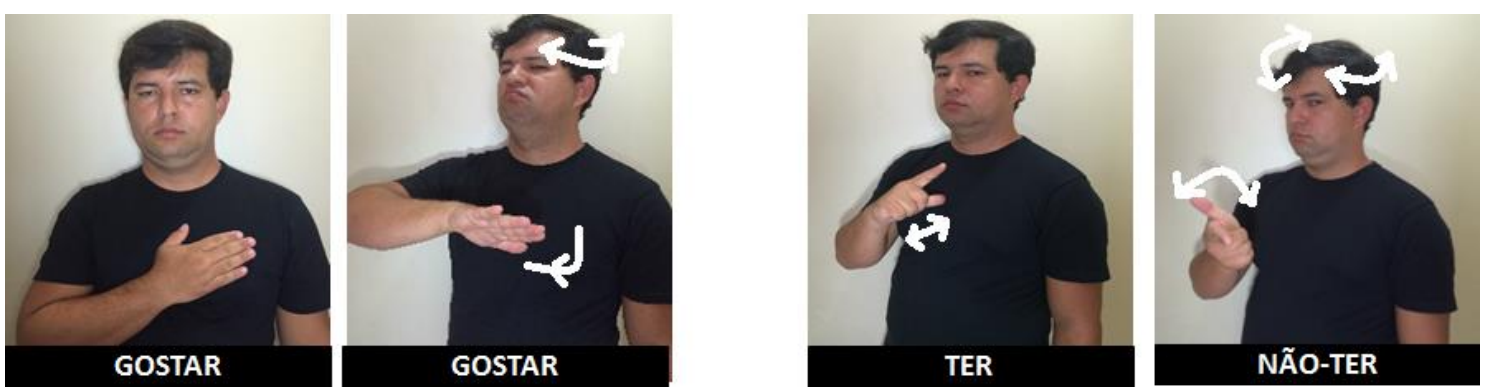

Sabemos que, em (24) NÃO-GOSTAR e NÃO-TER, diferentemente do que sugerem as pesquisadoras, não há adição de um afixo, a não ser que se considere o movimento de cabeça como afixo. Quadros e Karnopp (2004) elencam os exemplos mas não elucidam.

E, como descrito na seção anterior, há também alguns verbos que incorporam sujeito e objeto, como os verbos de concordância (Quadros e Karnopp 2004, p. 118)
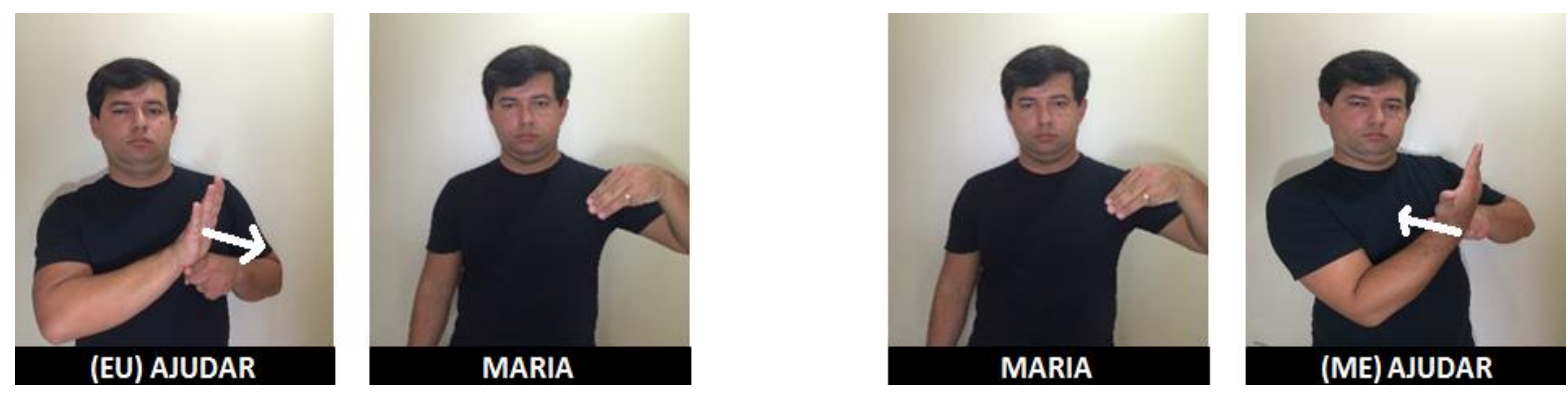
Em Linguística, sobretudo para os funcionalistas, costuma-se definir incorporação como um processo morfológico em que nome e verbo se combinam para formar um novo item lexical (cf. MITHUN 1984). Para essa pesquisadora, trata-se de um processo que, apesar das características sintáticas, não tem como objetivo formar novas estruturas sintáticas. Ao combinar nome e verbo, cria-se um novo verbo.

Mas, após observar os diferentes contextos em que o termo incorporação aparece na literatura sobre Libras, consideramos que ele esteja sendo usado de forma genérica, inespecificada. Nem sempre o termo é capaz de expressar os fenômenos linguísticos associados a ele. Parece-nos que a literatura trata como incorporação vários fenômenos de composição. Em alguns momentos de nossa pesquisa, sobretudo ao citarmos ideias de outros autores, mantemos o termo incorporação. Há também aí a necessidade de pesquisas que aprofundem esse assunto.

\subsection{Considerações do capítulo}

Neste capítulo, apresentamos uma breve revisão da sintaxe em Libras. Inicialmente, consideramos bastante relevante, ao nosso objeto de pesquisa, observar a ordem dos constituintes na sentença. Outro ponto merecedor de destaque é a classificação dos verbos em Libras. Por notar o reiterado uso do termo incorporação em diversos estudos, apresentamos uma seção para tratar desse fenômeno. Não poderíamos falar de Libras sem apresentar exemplos em sinais para ilustrar a leitura. Por isso, utilizamos o recurso de imagens para facilitar a compreensão do que se discutia. 


\section{CAPÍTULO 3 -SINTAXE FUNCIONAL-TIPOLÓGICA E CAUSATIVIDADE}

\subsection{Introdução}

Neste capítulo, apresentaremos o referencial teórico funcionalista, corrente norteadora da presente pesquisa. Dedicamos uma seção, a de 3.1, para abordar o funcionalismo e a tipologia. Aí, abrimos subseções para tratar das relações gramaticais e da ordem dos constituintes. Na seção 3.2, apresentamos o recorte teórico sobre causatividade. As subseções que seguem definem a causatividade e apresentam seus diferentes tipos.

\subsection{Funcionalismo e Tipologia}

O termo funcionalismo, utilizado com muita frequência em estudos de antropologia e sociologia, relacionado a teorias ou métodos de análises contrastantes é segundo Lyons (1987) - na linguística, um movimento em que estrutura fonológica, gramatical e semântica das línguas é determinada pelas funções a exercer nas sociedades em que operam. De acordo com Lyons (2009), os representantes mais conhecidos do funcionalismo são os membros da Escola de Praga, que teve origem no Círculo Linguístico de Praga, em 1926, quando um grupo de estudiosos iniciou os trabalhos nessa área. Surgia ali um grande movimento em linguística.

\footnotetext{
Um dos interesses duradouros da Escola de Praga, no que diz respeito à estrutura gramatical das línguas, foi a perspectiva funcional da sentença (para usar o termo que enfatiza a motivação funcionalista de pesquisa nesse assunto). Foi observado que (1) Hoje de manhã ele levantou tarde e (2) Ele levantou tarde hoje de manhã podem ser encaradas como versões diferentes da mesma sentença ou, alternativamente, como sentenças diferentes [...] Na medida em que a ordenação das palavras é considerada uma questão de sintaxe, podemos dizer que, pelo menos em algumas línguas, a estrutura sintática dos enunciados é determinada pela situação de comunicação em que é pronunciada. (LYONS, 2009, p. 168)
} 
Entendemos que o funcionamento de uma língua extrapola a preocupação exclusiva com competências para a organização gramatical de frases. Ao analisarmos a língua a partir do seu uso, nas mais diversas situações comunicativas é evidente que tais situações não retratam uma "estrutura estável e pressuposta", nem tampouco uma "aquisição inata". Assim, nessa certeza do dinamismo das línguas, e preocupados com aspectos de "como a língua é usada" ou "como a língua funciona", o leitor frequentemente poderá observar, na aplicação de nossa pesquisa, o referencial teórico funcionaltipológico.

Apesar do funcionalismo, desde a Escola de Praga, ser subdividido em escolas e teorias, os funcionalistas são unânimes em postular que a estrutura dos enunciados é determinada pelo uso, bem como o contexto comunicativo em que ocorrem, facilmente observados em alguns excertos.

Halliday, na Inglaterra, apresenta uma noção de função como o papel que a linguagem desempenha na vida dos indivíduos, e a define como:

No seu sentido mais simples, o termo 'função' pode ser entendido como um sinônimo para a palavra uso. (...) As pessoas fazem diferentes coisas com a linguagem; ou seja, elas esperam atingir, através da fala e da escrita, do ato de ouvir e da leitura, um grande número de diferentes objetivos e propósitos.

(HALLIDAY \& HASAN, 1989, p.15).

Para o norte-americano Givón (2001), não há autonomia do sistema linguístico em relação ao usuário. Enquanto a sintaxe codifica os domínios funcionais (semântica e pragmática), a gramática envolve cognição e comunicação, interação social e cultura, mudança e variação, aquisição e evolução, o que implica dizer que a pragmática do discurso desempenha um papel decisivo na explicação da sintaxe da linguagem. Para Cortez (2011, p. 70):

A sintaxe tem origem no discurso, pois, para ele [Givón], a linguagem humana evoluiu da pragmática à sintaxe. A noção de gramática para Givón (1979) remete às estratégias que o falante emprega criativamente para de forma funcional organizar seu texto a um ouvinte em um determinado contexto de situação. Essa noção assume a gramática como emergente, pois ela está sempre sendo modificada pelo uso da língua. Contudo, o autor admite, em seus trabalhos sobre gramaticalização, que fatores comunicativos e cognitivos estão na base das mudanças linguísticas. 
Dik, na Holanda, também manifestou interesse na tendência funcionalista:

\begin{abstract}
A teoria de Dik considera não só as funções que as estruturas gramaticais exercem no contexto discursivo, mas também as relações estabelecidas entre falantes e ouvintes na interação social. Nesse sentido, tal qual a proposta dos linguistas de Praga, a linguagem tem uma função teleológica, ou seja, sua finalidade última está relacionada ao êxito dos falantes no ato concreto da comunicação: a competência comunicativa. (NICHOLS 1984 apud MARTINS 2009, p. 27)
\end{abstract}

Para Gomes (2006, p.13) buscar explicações nas funções e nos processos diacrônicos recorrentes, os quais são em grande parte dirigidos por funções, é premissa do funcionalismo. Neves (1997) reconhece no funcionalismo a valorização de competências comunicativas, o que possibilita o entendimento dessas expressões de maneira interacional. É preciso ir além da palavra (sentença) para adentrar no contexto discursivo. Construtos teóricos são firmados através da análise das formas, não dissociando de um discurso construído, o que possibilita analisar componentes linguísticos (sintático-semânticos) na interação verbal (componente pragmático).

Segundo Cunha et al (2003, p. 29), o funcionalismo difere de abordagens formalistas por conceber a linguagem como instrumento de interação social e por interessar-se na investigação linguística para além de uma estrutura gramatical, buscando no contexto discursivo a motivação para os fatos da língua.

Observada algumas asserções funcionalistas, não será coincidência encontrar em nossas análises viés dessa linha de pesquisa.

\title{
3.1.1 Relações gramaticais
}

As relações gramaticais, frequentemente presentes na literatura como RG, definem orações sintaticamente. Para Payne (1997, p. 129), as relações gramaticais são frequentemente pensadas como as relações entre argumentos e predicados. 
Para Comrie (1989), assim como papéis semânticos e pragmáticos são descritos para os SN de inúmeras línguas, existem relações sintáticas que se manifestam entre um predicado e seus $\mathrm{SN}$, as chamadas relações gramaticais.

A literatura geralmente apresenta como RG mais comuns: sujeito, objeto direto e objeto indireto, em que sujeito e objeto direto assumem posições mais centrais, na maioria das línguas, Givón (2001). Como pode ser observado no exemplo abaixo:

10) O surdo entregou a prova para o aluno.

Na sentença (10), temos como RG: O surdo - sujeito; a prova - objeto direto e para o aluno - objeto indireto.

Givón (2001) ainda acrescenta que o papel semântico pode assumir um papel sintático e apresenta como proposta: um agente podendo ser sujeito; um paciente podendo ser sujeito ou objeto direto; um dativo podendo ser sujeito, objeto direto ou objeto indireto e todos os papéis semânticos podendo ser objetos indiretos. Ilustraremos através de exemplos na próxima seção.

Para Payne (1997), pesquisadores funcionalistas, dentre eles, Comrie, Dixon e Silverstein, na década de 1970, com o princípio de que a linguagem não é fortuita e nesse mesmo viés de que toda língua realiza operações que ajustam relações entre papéis semânticos e relações gramaticais na construção de enunciados, apresentam como proposta o estudo de papéis sintático-semânticos. A proposta, quase um convite a perceber as inúmeras particularidades que cada língua apresenta para expressar, por exemplo, as relações verbais, é intitulada, na literatura, como agrupamento $S$, $A$ e $P^{16}$ :

$\mathrm{S}$ - sujeito de orações intransitivas;

A - sujeito de orações transitivas e

$\mathrm{P}$ - objeto de orações transitivas.

No capítulo anterior, apresentamos as relações gramaticais em Libras. Na literatura atual, não há trabalhos exaustivos que analisem as relações gramaticais em Libras. Kinkade (1983), ao realizar um estudo de análise na língua salish (falada pelo

\footnotetext{
${ }^{16}$ Proposta apresentada por Comrie (1978), Dixon (1972, 1979,1994) e Silverstein (1976).
} 
povo indígena no noroeste da América do Norte), constatou que não há as categorias nomes e verbos. Em decorrência do nosso "olhar etnocêntrico" nas línguas "constituídas" de forma diferente, é comum perceber um certo estranhamento, afinal, fomos condicionados a olhar para a língua do outro buscando, equivocadamente, semelhanças com a nossa ${ }^{17}$. A pergunta básica da nossa pesquisa é: como as relações gramaticais se associam com papéis semânticos (e pragmáticos) em Libras? Qual seria a importância dessas relações na construção da causatividade em Libras?

\subsubsection{Papéis semânticos}

Analisemos os seguintes exemplos:

11) O homem matou o tigre;

12) Uma injeção letal matou o tigre e

13) O calor matou o tigre.

Podemos perceber que o tigre, cuja função sintática é a de objeto direto em 11, 12 e 13, assume a função semântica de paciente, afinal ele mudou de estado/forma com a ação sofrida. Grafamos em negrito a relação gramatical sujeito das 3 sentenças para que pudéssemos destacar que, embora sintaticamente sejam sujeito, semanticamente assumem diferentes papéis. Em 11, o sujeito $\mathbf{O}$ homem assume o papel semântico de agente - prototipicamente, é um ser animado (animacidade) que exerce de maneira consciente e voluntária (tem volição) uma ação capaz de promover a mudança no paciente, tigre. Diferentemente, Uma injeção letal e $\mathbf{O}$ calor não têm a mesma função semântica de ser o agente da ação por não apresentarem as propriedades semânticas de agente: injeção letal é instrumento, e calor é força. É possível perceber que, ainda que ocupem a RG de sujeito, podem assumir diferentes papéis semânticos. Para Payne (1997), embora esses papéis influenciem a morfossintaxe profundamente, eles não são categorias primariamente morfossintáticas. Eles são parte do "conteúdo" das mensagens linguísticas.

\footnotetext{
${ }^{17}$ Francisco Queixalós, comunicação pessoal.
} 
Assim, podemos concluir observando os enunciados 11, 12 e 13 que uma mesma relação gramatical - aqui sujeito - pode representar vários papéis semânticos - agente, instrumento e força, respectivamente. Em contrapartida, um mesmo papel semântico pode ser representado por diferentes relações gramaticais, como pode ser observado na passivização do enunciado:

14) $\mathrm{O}$ homem matou o tigre.

15) O tigre foi morto pelo homem.

O tigre do enunciado 14 sintaticamente é um objeto direto e semanticamente paciente. Já em 15, o tigre sintaticamente é sujeito, embora continue representando o papel semântico de paciente.

Em virtude das teorias gramaticais incorporarem a noção de papel semântico, algumas listas com as noções semânticas foram criadas. A seguir, os papéis semânticos mais frequentes para Payne (1997) e Givón (2001):

agente: prototipicamente, é um ser animado, tem volição para praticar ações e promover em um paciente uma mudança de estado - Maria beijou João;

paciente: prototipicamente, sofre uma mudança de estado sob efeito de uma causa externa (agente ou força) - Maria beijou João;

força: entidade não animada que afeta de maneira inconsciente e involuntária um paciente $-\underline{\mathrm{O} \text { vento }}$ derrubou a placa;

experenciador: ser animado que experimenta uma sensação ou um sentimento - $\underline{\text { Os }}$ surdos adoram Libras;

estímulo: presente na origem de sentimento ou sensação experimentado por um ser animado - A mãe ama o filho;

destinatário: ser animado ao qual algo ou alguém se endereça - João encaminhou email aos diretores;

beneficiário; ser animado que tira proveito de uma ação que não o afeta diretamente Eu comprei apostilas para os professores;

instrumento: objeto graças ao qual um agente efetua uma ação - João cortou o embrulho com estilete; 
localizacão/locativo: lugar onde se desenrola um evento, ou um lugar onde se situa uma entidade - As crianças estudam no Centro de Apoio aos Surdos (CAS);

destinação/alativo: lugar para o qual uma coisa ou alguém se desloca ou é transferido Eu vou ao CAS segundas e quartas;

proveniência/ablativo: lugar a partir do qual uma coisa ou alguém se desloca ou é transferido - Ele acabou de vir da FENEIS.

Ao pensarmos em língua como um contrato coletivo e social, é prudente dar relevância a algumas questões: sejam elas sociais, culturais e antropológicas. Qualquer indivíduo, que pleiteie dominar uma língua com competência comunicativa compreende que não basta decorar um conjunto de itens lexicais nem tampouco somente memorizar um conjunto de regras gramaticais. Geraldi (1984, p.44) considera que estudar a língua significa:

[...] tentar detectar os compromissos que se criam por meio da fala e as condições que devem ser preenchidas por um falante para falar de certa forma em determinada situação concreta de interação. [...] é muito mais importante estudar as relações que se constituam entre os sujeitos nos momentos em que falam do que simplesmente estabelecer classificação e dominar os tipos de sentenças.

Pensar nessa "situação concreta de interação" é preocupar-se com a compreensão do outro, afinal há uma necessidade (ou não) em fazer-me ser compreendido, de acordo com minha intenção, enquanto falante. Qual o objetivo do meu enunciado? Por que ao comparar enunciados como:

16) O traficante assassinou o garoto surdo e

17) O garoto surdo foi assassinado pelo traficante.

é incorreto afirmar que as frases são semanticamente equivalentes?

A ação de assassinar em 16, cujo sujeito A age sobre o sujeito B não equivale semanticamente a frase 17, de estado, não somente por apresentar duas entradas lexicais, ser assassinado, mas também por apresentar o sujeito B como atingido. Pensemos agora na manchete de jornal que tem como objetivo mostrar o agente desse crime bárbaro. Certamente a construção passiva estrategicamente não seria a escolha recomendada, afinal a matéria do jornal não apresenta como objetivo evidenciar um sujeito paciente. A relação entre gramática e discurso é indissociável. Como se "negociassem" durante todo 
o tempo. Para Marcuschi (2008), “[...] língua é o trabalho cognitivo e atividade social que pressupõe negociação [...]”.

\subsubsection{Ordem de constituintes, tópico e topicalização}

Considerar a linguagem como instrumento de interação social, que busca no contexto discursivo a motivação de fatos presentes na língua é postulado da abordagem funcionalista. O interesse pela investigação de aspectos linguísticos vai além de análises engessadas de estruturas gramaticais. Reconhecer a infinidade de possibilidades na construção de enunciados, por exemplo, nos leva a refletir sobre o porquê de algumas escolhas em detrimento de outras no processo comunicativo. A tarefa de organizar palavras em unidades maiores não é realizada de forma aleatória. Os falantes de uma língua não combinam esses elementos linguísticos de maneira fortuita para formar enunciados, mas sim atentando-se a regras, que são moldadas, dada a intenção comunicativa do falante.

A ordem das palavras nas sentenças já é investigada há muito tempo. De acordo com Pezatti (1997), o fenômeno é pesquisado de acordo com o enfoque da teoria e da metodologia adotadas. Analisemos os seguintes exemplos:

18) Os meninos quebraram a janela.

19) Foram os meninos que quebraram a janela.

20) A janela, os meninos quebraram.

21) A janela quebraram os meninos.*

Os enunciados (18), (19) e (20) seriam facilmente compreendidos por falantes de português. Pesquisas revelam o português brasileiro com uma orientação básica SVO, embora haja outras possibilidades na construção das sentenças. O enunciado (21) pode trazer dificuldades para compreensão, por i) sintaticamente não apresentar uma ordem/hierarquia conforme a gramática do português; ii) semanticamente a janela, um sujeito não-agente, executar uma ação (de modo volitivo) ao paciente.

Ao compararmos os enunciados (18) e (19), é possível perceber que as duas sentenças apresentam sentidos bem próximos e a ordem canônica do português brasileiro (SVO), ainda que tenham sido construídos de maneiras distintas. Qual seria o motivo 
dessa distinção? Segundo Pezatti (1997, p. 44), “Os SNs em uma sentença são apresentados na sequência desejada pelo falante para que o ouvinte atente para eles. Alterações de ordem como alterações de voz e topicalizações são mecanismos usados para trocar o fluxo de atenção". No enunciado (19), por exemplo, o destaque sintático no sujeito a partir da clivagem e com o auxílio da prosódia, coloca-o ainda numa posição de maior evidência, sem alterar a ordem dos constituintes, e evoca um contraste com algo dito anteriormente sobre a autoria da quebra da janela.

Para Neves (1997, p. 17), as sentenças são “unidades comunicativas” porque, ao mesmo tempo em que veiculam informações, estabelecem ligações com a situação de fala e com próprio contexto linguístico. A autora afirma ainda que, para os linguistas de Praga, a ordem das palavras constitui o principal fator de organização informativa da frase.

Conforme Martins (2009, p. 33),

\begin{abstract}
Postula-se que os conteúdos mais integrados no campo cognitivo também se manifestam com maior grau de integração no nível da codificação. Assim, prevê-se que quanto mais integrados cognitivamente forem os constituintes de uma palavra, de um sintagma, de uma oração ou de um parágrafo, maior será o grau de liberdade relativa entre eles. No que concerne ao subprincípio da informação, diz-se que a informação mais importante, mais previsível, mais tópica tende a ocupar o primeiro lugar na cadeia sintática. Logo, a organização ou a ordem dos constituintes, relacionada a considerações funcionais, revela aquilo que é mais importante para o falante.
\end{abstract}

Ao analisar o enunciado (20), A janela, os meninos quebraram, é possível perceber que, diferentemente das construções anteriores (18 e 19), em que se apresentava o objeto a janela em uma posição mais periférica, ocorre pragmaticamente sua promoção ao primeiro plano da cena discursiva, na posição de tópico. Esse processo, intitulado topicalização, apresenta especificidades bastante peculiares, de acordo com a língua, como na Libras, já mencionado no capítulo 2.

O tópico é apresentado como ponto de partida da enunciação. É a partir dali que o enunciador desenvolve um comentário. Assim, ao topicalizar, "uma fatia de informação mais importante é colocada à frente" (GIVON, 2001 apud VOTRE e RONCARATI, 2008 p. 171). Por que essa construção de enunciado? Em quais situações ela é mais utilizada com frequência? Vimos que a topicalização, em Libras, é algo bastante comum (cf. seção 2.2). Por que organizar um enunciado por meio de topicalização? Essa organização em 
Libras - em detrimento da ordem SVO ou qualquer outra ordem, descrita no capítulo 2 e analisada nos dados - nos revela que é o contexto de uso o responsável pela motivação de diferentes estruturas.

Neves (1997) define topicalização como função pragmática que tem como objetivo (também) especificar o estatuto informacional dos constituintes em relação à situação comunicativa. Assim, o tópico caracteriza as coisas de que falamos, como pode ser observado em:

22) O João entregou a nova apostila de Libras.

23) A nova apostila de Libras, João entregou.

24) A nova apostila de Libras foi entregue por João.

A topicalização, realizada nos enunciados (23) e (24), A nova apostila de Libras, é uma operação linguística utilizada pelas línguas em geral para que, de acordo com a intenção do falante, se topicalize um paciente e, em algumas situações, se apague um agente (já rebaixado). Para Givón (1979), é possível perceber claramente a topicalização em construções passivas analíticas, em que um não-agente é promovido a tópico e, consequentemente, o agente é rebaixado ou apagado. No enunciado (22) O João entregou a nova apostila de Libras, percebemos a ordem SVO. Quando comparada ao enunciado (24), A nova apostila de Libras foi entregue por João é possível perceber o rebaixamento do agente, que pode inclusive, ser apagado - uma das principais funções da voz passiva. Retomaremos a discussão no capítulo de análise dos nossos dados, para verificarmos, em Libras, qual seria a ordem básica mais comum nas construções causativas e se aí ocorre ou não topicalização. A seguir, entramos no tema principal de nossa pesquisa.

\subsection{Causatividade}

Ao assistir alguns vídeos em Libras (nas redes sociais) de surdos sinalizando sobre a falta de intérpretes em uma prova em Libras, no último concurso público para professor (de Libras) da Secretaria de Educação do Distrito Federal, foi possível observar que a 
Libras, como qualquer outra língua natural, utiliza-se de recursos para a manipulação de enunciados.
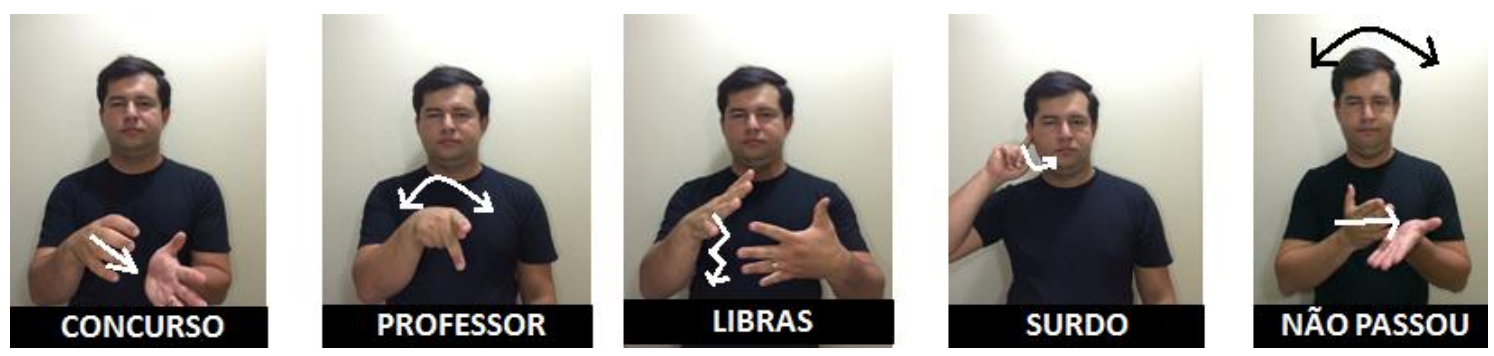

'Os surdos não foram aprovados no concurso público para professor de Libras.'

(27)
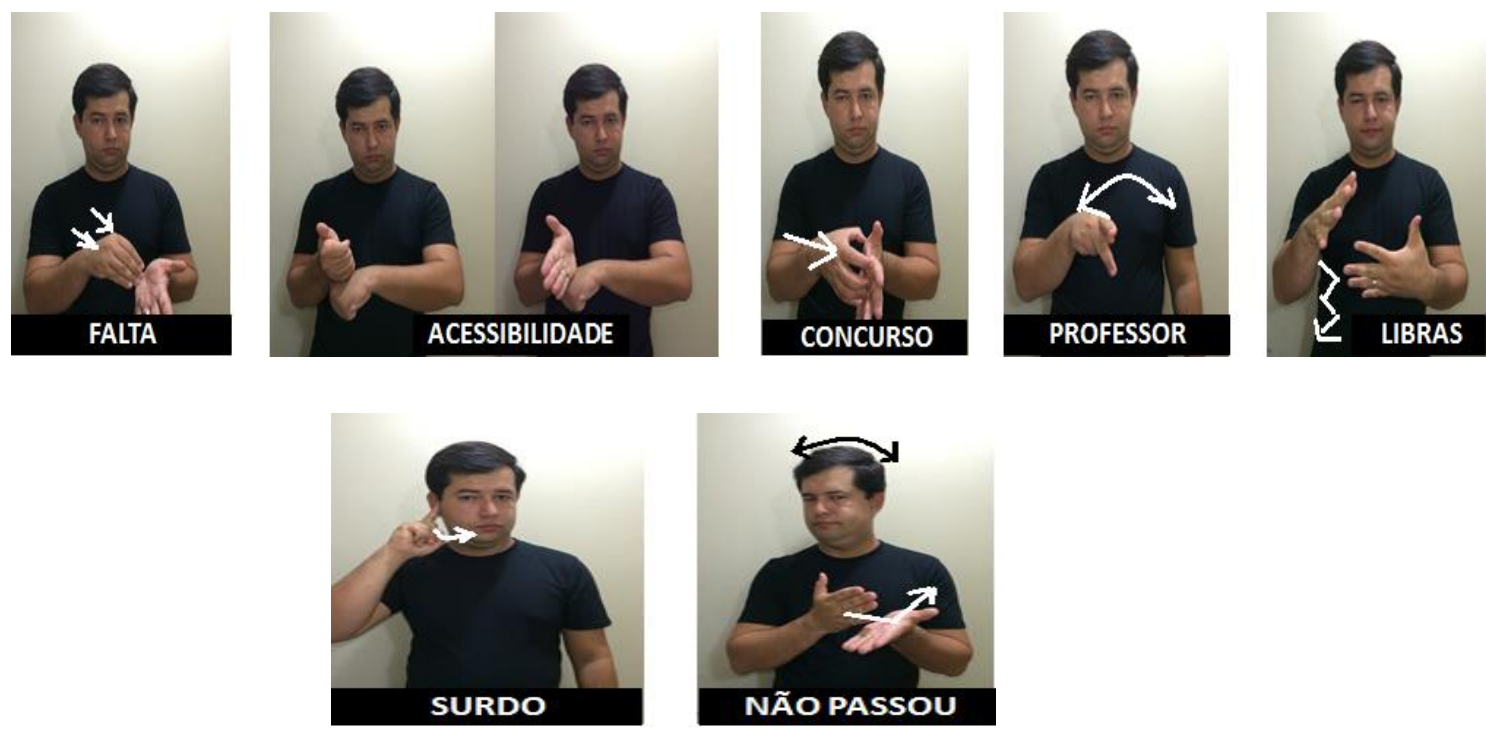

'A falta de acessibilidade fez com que os surdos não conseguissem aprovação no concurso público para professor.'

Ao observar a construção da perífrase em Libras, é possível perceber a predicação de causa e de efeito no enunciado. Algo que nos desperta curiosidade é de como o surdo reconhece o limite entre essa relação (causa e efeito)? Em português brasileiro, por exemplo, alguns elementos são utilizados para construir essa relação, como a subordinação: A falta de acessibilidade fez com que os surdos não conseguissem 
aprovação no concurso público para professor. É sabido que o elemento subordinador "com que" não é utilizado em Libras. Haveria uma outra estratégia na Libras para costurar os dois predicados? Um movimento no tronco do sinalizante? Uma pausa? Ficará mais essa pergunta para pesquisas futuras.

Fiorin (2005) afirma que um texto manipulado apresenta, dentre tantos outros objetivos, convencer o leitor a aceitar o ponto de vista do enunciador. Sabemos que a ausência do tradutor intérprete de Libras acarreta, sim, em abdicar acessibilidade aos surdos; porém, seria esse o único motivo pelo insucesso no certame?

Ao observar a estratégia utilizada para aumentar a valência no segundo enunciado, torna-se evidente a necessidade de trazer à cena um "controlador", como se disséssemos Não foi o surdo que não foi aprovado, e sim a falta de acessibilidade foi o motivo dos surdos não conseguirem a aprovação no concurso. Assim, na descrição do evento citado em 2, podemos perceber a existência de:

A) Uma causa: A falta de acessibilidade fez

B) Um efeito: que os surdos não conseguissem aprovação no concurso público para professor.

Ao associar um predicado de causa a um predicado de efeito, introduzindo na cena um causador, podemos afirmar que, semanticamente, construímos um enunciado causativo.

Tais construções, consideradas como um fenômeno linguístico natural, já foram observadas e documentadas em várias pesquisas de línguas orais. Até o presente momento, sobre esse assunto muito pouco foi encontrado na literatura das línguas de sinais e não encontramos pesquisas sobre construções causativas em Libras.

Mas, afinal, o que é causatividade? Existem similaridades nas construções causativas de línguas orais e línguas de sinais? Quais os aspectos mais relevantes observados nos dados por nós coletados? Nas próximas seções, tentaremos responder a tais questionamentos.

\subsubsection{O que é causatividade?}


Shibatani (2000) define "causatividade" como uma situação composta de dois eventos em que há um causador e um causado. Segundo o autor, há uma relação de dependência entre esses dois eventos, de forma que o evento ocorrido causado é dependente da ocorrência do evento causador. Na obra intitulada The causative continuum, Shibatani \& Pardeshi apresentam: 1) distinção direta/indireta da causação em relação à semântica verbal; 2) o verbo como vetor principal nas construções causativas; 3) provas convincentes para um continuum na formação do causador; 4) aspectos merecedores de atenção no parâmetro de produtividade, nas causativas e 5) evidências da importância de uma categoria intermediária de "sociative causation".

Para Givón (2001, p.165):

\begin{abstract}
As construções causativas têm desempenhado um papel importante na atual história da linguística, não só do ponto de vista tipológico, mas também por representar uma importante área de convergência entre linguística e algumas disciplinas adjacentes tais como filosofia (a natureza de causalidade) e antropologia cognitiva (percepção humana e categorização da causalidade).
\end{abstract}

Pensando nessa situação da cena discursiva composta de dois eventos, observemos algumas construções causativas no katukina ${ }^{18}$ (QUEIXALÓS, 2002, p. 233):

\title{
25) bak barahai
}

SerBom CarneDeCaça

'a carne é boa'

\section{6) aobatyawa-na bak-man barahai}

\section{MulherDele-Caso SerBom-Fazer CarneDeCaça}

'a mulher dele melhorou a carne'

\section{7) aobatyawa-na bak-tiki barahai}

MulherDele-Caso SerBom-Causativo CarneDeCaça

'a mulher dele ajeitou a carne'

18 O povo katukina vive em terras localizadas no Acre e Amazonas. 
Nos enunciados (26) e (27) de Queixalós (2002), vemos exemplos dos achados de Givón (2001) e Shibatani \& Pardeshi (2002): situações com dois eventos (predicado causa e predicado efeito). A presença de um novo participante nessas sentenças, a mulher dele, está também em consonância com os princípios de causatividade: relacionar um causador a um causado.

Pensando na causatividade como um fenômeno que associa essas relações, Neves (2000) a define como estruturas linguísticas formadas a partir de verbos causativos ou situações causativas cujos verbos são transitivos em que o sujeito (agente ou causa) age sobre outro indivíduo (ou coisa), forçando-o a realizar algo ou a se tornar algo, de modo a estabelecer essa relação de causa-efeito. Observemos alguns enunciados para ilustrar:

28) O professor fez o aluno estudar novos sinais.

Na sentença (28), temos o sujeito da primeira oração (ou oração principal, para muitos pesquisadores) o professor (causa) agindo sobre $o$ aluno, que por sua vez comete a ação de estudar novos sinais (efeito). O responsável em estabelecer a relação entre as duas orações, causa-efeito é o verbo fazer. Neves (2000) considera que as sentenças causativas são geralmente compostas por duas orações: uma principal e a outra

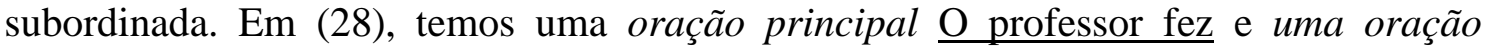
subordinada o aluno estudar novos sinais. Verbos como mandar, fazer, provocar e causar são exemplos de causativos em português.

Observemos um outro enunciado:

29) O aluno derrubou a apostila.

Em (29), diferentemente do enunciado (28), o verbo derrubar condensa o predicado de causa e o predicado de efeito. O fato do aluno ter derrubado a apostila implica uma mudança no estado da mesma. Podemos afirmar que $o$ aluno é a causa e $a$ apostila derrubada é o efeito da ação realizada pelo aluno.

Shibatani \& Pardeshi (2002) classificam as construções causativas tipologicamente em três formas. É o que veremos na subseção a seguir. 


\subsubsection{Tipos de causatividade}

Comrie (1989, p.165) define causatividade no âmbito dos estudos tipológicos e funcionais como uma macrossituação que envolve duas microssituações: a causa e seu efeito correspondente. Em decorrência das infinitas possibilidades de estratégias de uma língua para expressar a relação que envolve o causador (causa) e o resultado dessa ação do causado (efeito), seguindo a mesma abordagem, Comrie (1989) apresenta três tipos de causativas:

1) Lexicais;

2) Morfológicas e

3) Perifrásticas/ Analíticas.

Mas Shibatani \& Pardeshi (2002, p.85) consideram a questão mais complexa:

Estudos tipológicos classificam as formas causativas em: (a) lexical (sintética), (b) morfológica, (c) sintática (analítica ou perifrástica). Encontramos nessa perspectiva tipológica algumas limitações. Como notado por Givón (1980) e Comrie (1981, 1985), esses três tipos organizam-se num continuum, cada tipo específico consiste ele mesmo em um Continuum próprio, tornando toda a dimensão formal, num único continuum. [...] Nós apresentamos uma análise tipológica funcional de construções causativas na forma de um mapa semântico que mostra como formalmente diferentes tipos de causas são distribuídas ao longo das dimensões da semântica. O mapa também representa o padrão da gramaticalização, assim fornece um quadro no qual distribuição sincrônica e diacrônica são desenvolvidas em várias construções causativas, que podem ser diretamente relatadas. (Tradução nossa) ${ }^{19}$

A seguir, apresentamos cada tipo e aspectos desse continuum a que se refere Shibatani \& Pardeshi (2002):

\footnotetext{
${ }^{19}$ In a typological study it is customary to classify causative forms into (a) the lexical (synthetic), (b) the morphological and (c) the syntactic (analytic or periphrastic type). We find a formal typology of this kind to be limited in a number of respects. For one thing, as noted by Givón (1980) and Comrie (1981, 1985), these three types form a continuum, and each type, furthermore, consists of a continuum of its own, rendering the entire formal dimension into a single continuum. [...] We present a functionaltypological analysis of causative constructions in the form of a semantic map that shows how formally distinct types of causative are distributed along the directness dimension of the causative semantics. The map also represents the pattern of grammaticalization, thereby providing a framework in which synchronic distribution and diachronic developments of various causative constructions can be directly related.
} 


\subsubsection{Causativas lexicais}

Segundo Givón (1979), predicados mais simples podem tornar-se mais complexos através do processo da causativização lexical, que amplia o predicado. Como ocorrem com os exemplos (30a) e (30b), de construções causativas do japonês, retirados do continuum de Shibatani \& Pardeshi (2002, p. 87) (traduzimos a glosa e tradução, que estavam em inglês, para o português):

30) a. Kabin-ga ware-ta.

vaso-NOM quebrar-PAST

'O vaso quebrou.'

b. Taroo-ga kabin-o wat-ta.

NOM vaso-ACC quebrar-PAST

'Taro quebrou o vaso.'

Analisemos outro exemplo de causativa lexical:

31) a. Bill died

'Bill morreu.'

b. John killed Bill.

'João matou Bill'

(Lyons 1968, p. 352)

Para Givón (1979), a relação entre o intransitivo (31a) e o transitivo (31b) está "lexicalizada". A estrutura lexical determina dizer John killed Bill e não *John died Bill. Verbos como morrer X matar e cair X derrubar, em português ou see X show, em inglês, também exemplificam construções causativas lexicais. 


\subsubsection{Causativas morfológicas}

De acordo com Comrie (1981), quando um verbo não causativo sofre aumento de valência mediante o acréscimo de morfemas causativos, está presente aí a causativa morfológica. Assim, o verbo sofre um processo derivacional por meio de afixos para expressar a causa e trazer para a cena discursiva o superagente. Vejamos um causativo morfológico no turco:

32) a. Hasan öl-dü

morrer-PAST

'Hassan morreu'

b. Ali Hasan-i öl-dür-dü

-ACC morrer-CAUS-PAST

'Ali fez Hasan morrer, matou Hasan'.

(COMRIE, 1985, p. 331)

Em (32b), não há alteração na forma verbal porém, o verbo é acrescido de um afixo que morfologicamente é capaz de relacionar o evento causa ao evento efeito.

\subsubsection{Causativas perifrásticas/analíticas}

Segundo Comrie (1985), as causativas perifrásticas (também encontradas na literatura como analíticas) não são realizadas através de uma oração simples, de forma que o elemento causativo não se encontra no verbo da oração não causativa. Isso implica dizer que o predicado que expressa a noção de causa e o predicado de efeito dessa causa estão sintaticamente separados. Assim, as causativas perifrásticas apresentam um agente (ou causa) que age sobre outro que, por sua vez, desencadeia um efeito, como em $O$ surdo fez a mãe aprender Libras. Neves (2000) considera que, em uma causativa perifrástica, há uma oração principal ( $O$ surdo fez) e uma oração subordinada (a mãe aprender Libras). O sujeito da oração principal $O$ surdo (causa) age sobre a mãe, causando nesta uma ação, a de aprender Libras (efeito). Outros exemplos de causativas perifrásticas, apresentadas no continuum de Shibatani \& Pardeshi (2002, p. 154): 
33) Alemão:

Hans liess seinen Sohn den Brief abtippen.

'Hans fez seu filho digitar a letra'

34) Francês

J'ai fait preparer la maionese à Jean.

'Eu fiz Jean preparar a maionese'

Em consonância com os estudos de Comrie (1985), Shibatani \& Pardeshi (2002) apresentam em (33) e (34) uma oração principal e uma oração subordinada de modo que o agente da oração principal age sobre outro agente (da oração subordinada) para o desfecho do evento. Em Português, diferentemente do Francês, esse segundo agente assume propriedades sintáticas de sujeito, fazendo o verbo flexionar: Eu fiz Jean e Maria prepararem a maionese.

\subsubsection{Causação direta ou indireta?}

Como vimos, são três as estratégias que as línguas utilizam na elaboração de construções causativas: lexicalização (causativa lexical); afixos que morfologicamente relacionam causa/efeito (causativa morfológica), além das estratégias de perífrase (causativa perifrástica). Assim, ao nos atentarmos às estruturas semânticas na elaboração de enunciados, é possível ainda classificar as causações em mais diretas ou menos diretas (indiretas), conforme Shibatani (2000).

Na causação direta, o sujeito do evento de causa age diretamente sobre o sujeito do evento causado: Dilma demitiu o ministro da educação. Diferentemente, na causação indireta, não há essa ação diretamente sobre o causado: Dilma fez o ministro da educação se demitir.

Com objetivo de ilustrar a causação direta e indireta, apresentamos o modelo utilizado por Shibatani \& Pardeshi (2002, p. 90) no "the causative continuum”. 


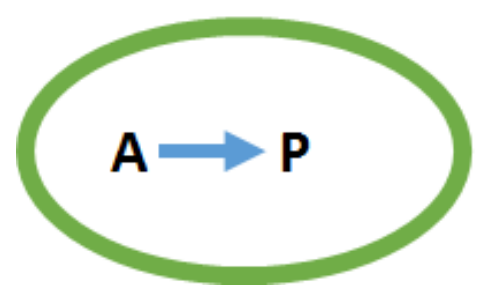

Figura 11: Causação direta

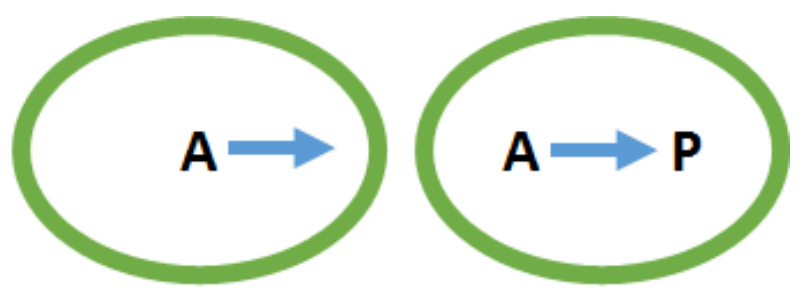

Figura 12: Causação indireta

Na figura 11, é possível perceber um agente (A) agindo diretamente sobre um paciente $(\mathrm{P})$ e, por esse motivo, a causa torna-se direta. Já na figura 12, há uma sequência de eventos, iniciada no (super)agente (A), que, por sua vez, é apenas o mandante e não (obrigatoriamente) o executor, resulta no evento final, uma causatividade indireta (o segundo A pode ser, inclusive, outra pessoa). Como também pode ser observado nos exemplos utilizados por Shibatani \& Pardeshi (2002, p. 90):

35.1) John melted the metal.

35.2) John caused the metal to melt.

Embora tenhamos semanticamente o mesmo evento resultante da ação, o metal derretido, há diretividade maior no enunciado A, em que John provavelmente atuou diretamente no derretimento do metal. O enunciado B é usado quando John se utiliza de alguém ou de algum meio para derreter o metal, mas pode não estar diretamente/fisicamente envolvido. Em B, John causou o derretimento do metal, o que o coloca em uma posição ainda de maior controle. Optamos pelo termo superagente para definir esse "controlador", acrescido aos enunciados. Esse termo será muito empregado durante a análise dos dados no capítulo 5. Gomes (2014) define o termo super(agente) como aquele participante de uma cena discursiva cuja função é a de causador ou controlador pleno do desenrolar de uma trama exposta (GOMES 2014, p. 258), premissa básica para uma construção causativa.

Ao analisar as sentenças (35.1) e (35.2), é possível afirmar que há nessa língua mais de um tipo formal de causativa. Para Givón (1984), essa distância estrutural, em que a menor sentença será usada em detrimento de uma sentença maior, tende a expressar uma causação mais direta. Assim, o número de sílabas ou segmentos envolvidos na 
operação causativa é iconicamente relacionado à distância entre causa e efeito. O mesmo ocorre em:

36.1) O CAS exonerou o coordenador de Libras.

36.2) O CAS fez o coordenador de Libras se exonerar.

A construção do enunciado (36.1) é classificada como mais direta (cf. SHIBATANI 2000) por apresentar o sujeito do evento de causa agindo diretamente sobre o sujeito do evento causado. Tal afirmação corrobora os estudos de Givón (1984) afinal, ao observar a sentença (36.1) é possível perceber o menor número de segmentos envolvidos na operação causativa, quando comparada à sentença (36.2). Vejamos o que sugere a pirâmide de iconicidade de Haiman (1983) a esse respeito:

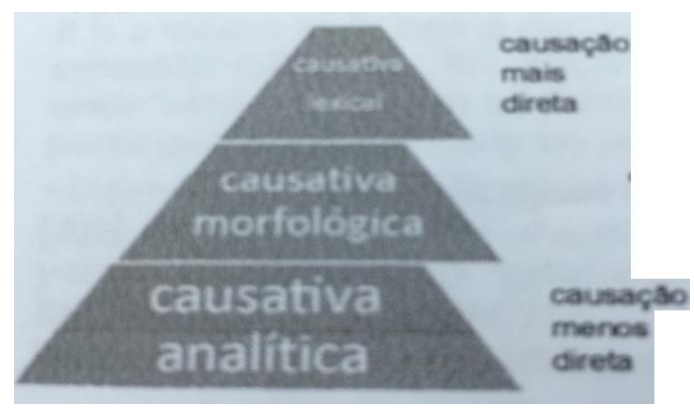

Figura 13: Pirâmide de iconicidade de Haiman (1983)

\subsection{Considerações do capítulo}

O presente capítulo buscou apresentar de maneira sucinta alguns parâmetros da sintaxe funcional-tipológica enviesando ao objeto de nossa pesquisa e, para isso, procurou focar nas relações gramaticais e no estudo da ordem. Na sequência, apresentamos uma revisão sobre os estudos de causatividade baseados, sobretudo, no continuum de Shibatani \& Pardeshi (2002). Algumas construções causativas foram apresentadas em diferentes línguas para observarmos diferentes manifestações. No capítulo seguinte, apresentaremos a metodologia proposta para observar como se manifestam as construções causativas em Libras. 


\section{CAPÍTULO 4 - METODOLOGIA E CORPUS}

\subsection{Introdução}

Neste capítulo discursaremos o passo a passo dado para a coleta e análise dos dados. Ao realizar uma pesquisa no campo da Linguística com o objetivo de observar como se manifestam alguns fenômenos da língua em uso, uma grande preocupação é de como levantar dados necessários para a realização das análises. Chafe (1994) salienta sobre a importância dos tipos de dados públicos ou privados e manipulados ou naturais durante o processo de pesquisa, em consonância com os objetivos propostos pelo estudo.

Para melhor compreensão da metodologia utilizada para o desenvolvimento do corpus, dividimos o presente capítulo em três partes. Na seção 4.1, apresentaremos nossos colaboradores surdos. Em 4.2, discutimos sobre o processo da manipulação dos vídeos, desde o momento em que o surdo gerava um dado ao registro dele. Na subseção 4.2.1, apresentaremos o software Elan bem como as estratégias utilizadas com o programa. Observemos, então, nas seções seguintes como ocorreu o registro e análise dos dados bem como as dificuldades encontradas durante esse processo.

\subsection{Os roteiros de coleta de dados}

Inicialmente, pensamos na coleta de dados a partir de elicitações oriundas de ilustrações. A pergunta seguinte era: como produzir ilustrações que se aproximassem de enunciados como:

1) O João saiu de casa.

2) A Maria fez o João sair de casa.

Contratamos um surdo para ilustrar algumas elicitações a serem utilizadas na pesquisa. Inicialmente, para nosso primeiro roteiro exclusivamente ilustrado, 3 cenas, escolhidas previamente por nós pesquisadores, foram desenhadas para gerar os primeiros 
dados. Explicamos ao surdo sobre a necessidade de desenhar detalhes que se aproximassem de:

1 - O copo quebrou.

2 - O menino derrubou o copo.

3 - O menino fez o copo cair.

Com as cenas já ilustradas, convidamos colaboradores surdos, sinalizantes de Libras, para sinalizar diferentes enunciados previamente organizados por nós.

$1^{\circ}$ Roteiro (ilustrado)

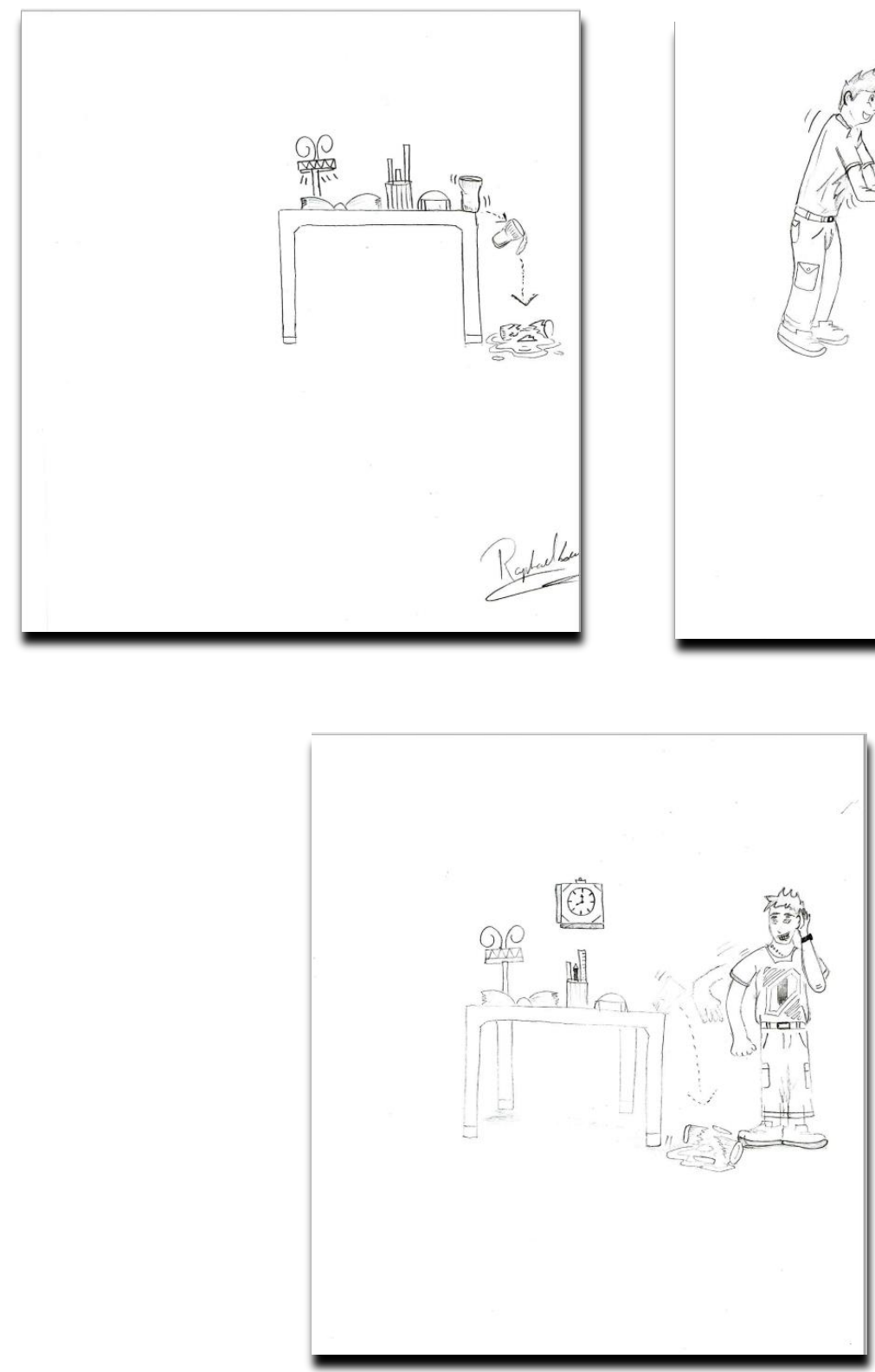


Os surdos, individualmente, observavam as três imagens e embora quisessem perguntar sobre o desenho, recebiam como orientação que não poderíamos participar da tradução; assim, deveriam produzir, em Libras, o que visualizavam na imagem. A técnica com a ilustração no papel, embora tenha apresentado resultados satisfatórios, gerou dúvidas na compreensão do desenho. Um de nossos colaboradores perguntou o motivo do desaparecimento dos objetos no segundo quadro quando comparado ao terceiro quadro. Informações não tão relevantes para o estudo eram solicitadas, como o relógio na parede presente somente no terceiro quadro. A expressão do garoto também recebeu reclamações de quase todos os participantes. Resolvemos intervir e recorremos a textos em português para complementar as informações que somente as ilustrações não eram capazes de apresentar. Surgia nosso segundo roteiro, escrito e ilustrado

$2^{\circ}$ Roteiro (escrito/ilustrado)

\section{O menino não gosta de maçã. 0 menino está doente e precisa de uma alimentação saudável. A mãe do menino manda que ele coma a maçã. Ele não quer comer a maçã. A mãe orienta o menino para que ele coma a maçã.}

Imagem 1

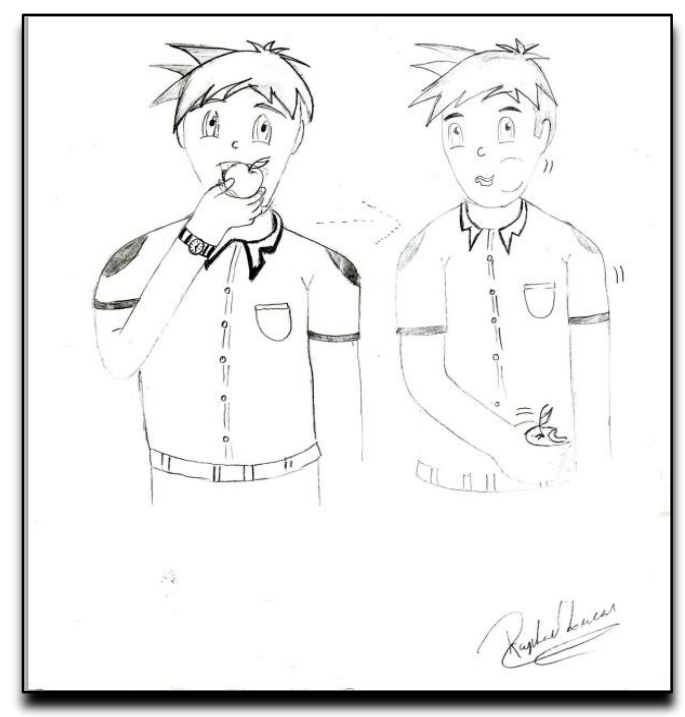

Imagem 2

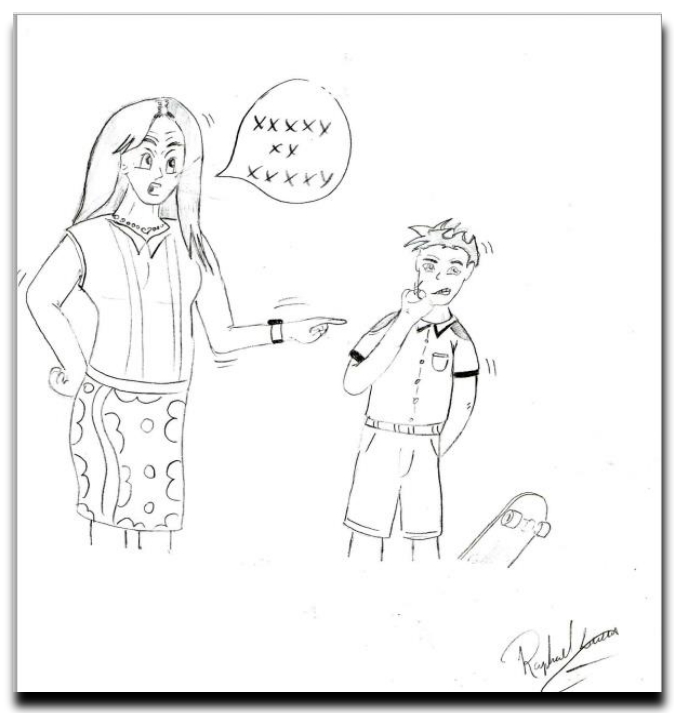


Imagem 3

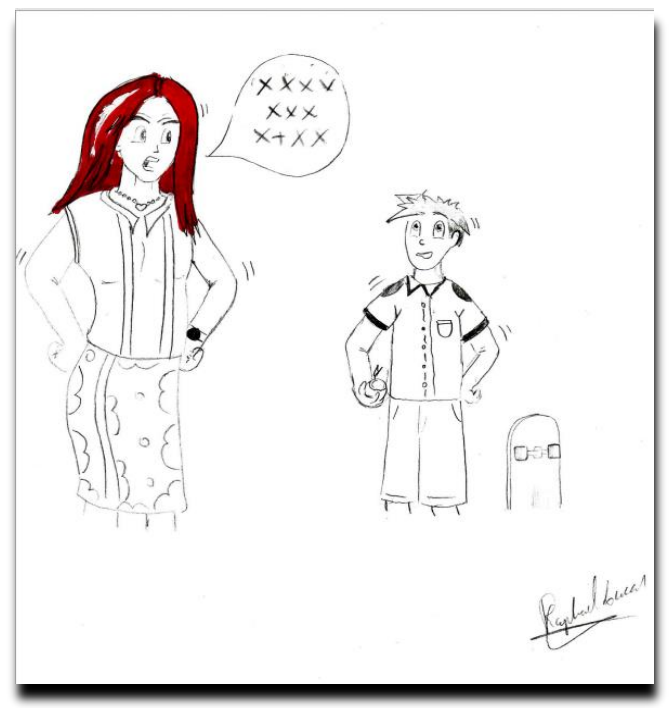

Esperávamos ter como tradução aproximada em português:

1) O menino comeu a maçã.

2) A mãe fez/obrigou o menino comer a maçã.

3) A mãe orientou o menino a comer a maçã.

Todos os nossos colaboradores reclamaram do desenho. Apenas um colaborador não perguntou a diferença entre os quadros 2 e 3. Mesmo recorrendo à breve explicação do texto escrito em português para auxiliar a compreensão dos desenhos, questionamentos como o skate na cena da criança doente ou o apontar do dedo da mãe (quadro 2) para expressar mais (ou menos) raiva, continuavam presentes. Um de nossos colaboradores construiu uma narrativa ao observar o primeiro quadro e, ao interpelarmos sobre toda a narrativa contada observando somente o primeiro quadro, ele justificou que foram as informações do texto escrito. Embora tivéssemos acertado de que não conversaríamos no momento da gravação, alguns esclarecimentos foram feitos excepcionalmente neste roteiro, devido à complexidade em diferenciar os quadros 2 e 3 . Foi necessária uma breve explanação em Libras.

Em nossa terceira etapa, recorremos a roteiros escritos com frases em português para que nossos colaboradores lessem e produzissem, individualmente, as sentenças em Libras. Ao ler cada uma das sentenças, filmávamos a tradução em Libras. Esse terceiro roteiro (escrito), diferentemente das etapas anteriores, não gerou dúvidas na compreensão 
dos enunciados. Nossos colaboradores inclusive esboçaram mais apreço em participar do estudo com essa nova tentativa.

O primeiro roteiro escrito apresentado:

1) O cachorro morreu.

2) O menino matou o cachorro.

3) O menino fez o cachorro morrer.

E o segundo roteiro escrito:

1) A menina entristeceu.

2) A chuva entristeceu a menina.

3) A chuva fez a menina ficar triste.

Numa quarta etapa, ao conversarmos sobre causatividade, criamos situações hipotéticas que foram apresentadas para alguns colaboradores. Por exemplo, se uma criança cair e machucar ou um objeto causar a queda e o ferimento, como seriam essas construções em Libras? A partir dessa conversa, obtivemos alguns dados que também fazem parte do nosso processo de análise.

Por fim, apresentamos também outros dados oriundos de situações observadas no dia-a-dia, em busca de um discurso mais natural, como vídeos nas redes sociais que tratavam de temas diversos. Elegemos um assunto, que causou bastante repercussão: a falta de uma prova em Libras, durante o último Exame Nacional do Ensino Médio (ENEM). E a partir daí selecionamos trechos para apresentar aos colaboradores sobre essa discussão. Na sequência, elaboramos a seguinte pergunta:

Por que os surdos não conseguem boas notas no ENEM?

E obtivemos as mais diferentes respostas, dentre elas selecionamos duas respostas que consideramos bem pertinentes à pesquisa e serão apresentadas no próximo capítulo.

Durante todo o processo de coleta e análise, tivemos o cuidado de buscar sempre nos aproximar da enunciação. Segundo Hanks (2008), pesquisas sobre a linguagem nas últimas décadas têm se focado na relação entre linguagem e contexto. Trabalhos nas mais diversas áreas (antropologia linguística, sociolinguística, pragmática, psicolinguística, e filosofia da linguagem) apresentam formas em que língua e informação são moldadas por 
contextos sociais e interpessoais para que haja o discurso. Segundo o pesquisador, o contexto deve ser algo construído pela enunciação, e pela enunciação no curso da conversação, assim, durante todo o processo de pesquisa, buscávamos esse contexto.

\subsection{Os colaboradores surdos e a coleta de dados}

Desde a gestação do projeto, pensávamos no convite aos colaboradores da pesquisa. Inicialmente, pensamos em quatro colaboradores surdos para compor o grupo. Nosso desejo era que os colaboradores surdos fossem usuários da Libras e, preferencialmente, que não fizessem uso do português na modalidade oral, visando enunciados que não estivessem ancorados na língua portuguesa. $\mathrm{O}$ grupo aumentou e contamos com a participação de oito colaboradores. Destes, seis nasceram em Brasília e somente dois não, apesar de morarem aqui há mais de quinze anos. O grupo de participantes utiliza a Libras como forma exclusiva de comunicação e é constituído de homens e mulheres para que fosse possível observar se a questão do gênero revelaria algo à pesquisa. Os colaboradores são atuantes na Federação Nacional de Educação e Integração dos Surdos (FENEIS). Todos têm formação superior (em cursos diversos), sendo três especialistas e três mestres. A faixa etária dos participantes é de 30 a 40 anos e todos, sem exceção, fazem uso da Libras há mais de uma década.

Ao aceitar o convite, cada um dos colaboradores assinou um Termo de Consentimento Livre e Esclarecido (cf. modelo do TCLE no apêndice A) e preencheu um questionário sociolinguístico com questões que abordam a trajetória linguística na aquisição da Libras, além de outras questões pertinentes à pesquisa (Apêndice B).

Durante o processo de coleta de dados, os colaboradores foram expostos a diferentes recursos, incluindo imagens, textos escritos e sinalizados para a produção de elicitações. O primeiro passo realizado pelos colaboradores foi a observação do roteiro 1, que continha três cenas ilustradas mostradas na seção anterior e que foram apresentadas uma a uma. Parte dos colaboradores, ao observar a ilustração, perguntou sobre o desenho no papel, porém respondemos que apenas sinalizassem em Libras cada uma das cenas, evitando qualquer interferência entre pesquisador e colaborador. Alguns colaboradores perguntaram também se poderiam sinalizar o mesmo enunciado para os desenhos de 
número 2 e 3 que, segundo eles, não apresentava diferenças significativas. Mais uma vez, solicitamos que apenas sinalizassem o que haviam compreendido na leitura das imagens.

No segundo roteiro (mostrado na seção anterior), consideramos pertinente acrescer algumas informações e redigimos um pequeno texto escrito para que nossos colaboradores lessem antes de observar as imagens. Em virtude de quadros muito parecidos (ilustrados no papel), os colaboradores perguntavam se havia diferença entre as cenas desenhadas, como ocorrera com o primeiro roteiro.

O terceiro roteiro continha frases em português escrito para que os colaboradores, após a leitura, sinalizassem em Libras. Abaixo, retomamos parte de um dos roteiros apresentados na seção anterior:

1) O cachorro morreu.

2) O menino matou o cachorro.

3) O menino fez o cachorro morrer.

É importante mencionar que, durante todo esse processo de escolha dos colaboradores, conversas de esclarecimento sobre a pesquisa e apresentação de elicitações, sejam elas ilustradas ou escritas, tínhamos a oportunidade de, após a filmagem, conversar sobre alguns dados produzidos e, inclusive, sobre outras questões pertinentes à pesquisa. Todos os colaboradores, ao ler cada uma das frases, traduziam para Libras na mesma sequência. Dos oito colaboradores, apenas um não compreendeu a última sentença dos roteiros e optou por fazer uma tradução literal. Partindo do princípio de que um único colaborador não compreendeu o enunciado, consideramos adequado não apresentar os dados desse colaborador, específico, no capítulo referente à análise de dados. Talvez, se tivéssemos um número mais significativo de colaboradores, poderíamos perceber com mais propriedade se a incompreensão do enunciado é uma situação isolada ou carece de atenção, sobretudo no ensino do português, na modalidade escrita, como segunda língua para surdos. Ressaltamos que os colaboradores surdos compreendiam português escrito.

Em nossa última etapa de coleta dos dados, assistimos a alguns vídeos durante as reuniões da FENEIS, para que pudéssemos identificar as falhas da acessibilidade no 
Exame Nacional de Ensino Médio - ENEM. Esses vídeos assistidos seriam o suporte para a produção de um relatório, narrando sobre a falta de acessibilidade durante o exame. E surgiu a ideia de, enquanto pesquisadores, perguntar aos surdos presentes na reunião o porquê do insucesso no exame. Das respostas de grande parte dos colaboradores, identificamos sentenças bastante pertinentes ao estudo e, por esse motivo, serão apresentadas no capítulo seguinte.

Após uma reunião da FENEIS, conversávamos sobre a construção de sentenças em Libras quando questionei um surdo como seria em Libras os seguintes enunciados:

1) O menino machucou o pé.

2) O skate machucou o pé do menino.

3) O skate fez o menino machucar o pé

Os dados em Libras serão apresentados no capítulo referente à análise.

Em virtude das reuniões da FENEIS ocorrerem semanalmente ou quinzenalmente, tínhamos a oportunidade desse encontro frequente e da possibilidade de, ao analisar os dados, contar com o apoio dos próprios surdos na discussão dos resultados das análises, ponto bastante positivo para o desenvolvimento da pesquisa.

Tivemos muitas horas de gravação de cada um dos colaboradores. No entanto, para evitar a repetição excessiva de alguns dados ou, ainda, objetivando tornar a análise mais dinâmica, evidenciando dados que revelavam algo novo e pertinente ao estudo, selecionamos alguns desses dados para compor o capítulo seguinte, o da análise. Em virtude das horas de filmagem, não foi possível analisar todos os dados, que podem inclusive contribuir para pesquisas futuras.

\subsection{Gravação dos vídeos}

Para realizar as filmagens, colocamos duas filmadoras na sala que utilizamos para as gravações. Nosso maior objetivo era captar todas as imagens sinalizadas do pesquisador e do colaborador durante o processo de entrevista. Nas gravações realizadas 
durante o dia, utilizamos somente a iluminação natural da sala, diferentemente das gravações realizadas no período da noite, em que recorremos às luminárias e as dispusemos no chão. Antes mesmo de iniciar qualquer registro, o pesquisador conversou com cada um dos colaboradores, explicando sobre a pesquisa e as possíveis participações. Como já dissemos na seção anterior, os colaboradores assinaram um TCLE.

No momento da gravação, não havia diálogo entre os colaboradores ou mesmo entre pesquisador e colaborador. O pesquisador apresentava imagens e textos escritos ao pesquisado. E, quando surgiam dúvidas quanto ao desenho ou enunciado escrito, o pesquisador apenas solicitava que o colaborador sinalizasse em Libras o que havia compreendido. As filmagens foram realizadas em vários momentos distintos, porém com muita tranquilidade. Por tratar de enunciados curtos, as gravações não eram exaustivas e alguns colaboradores expressavam a satisfação de participar de um estudo em sua língua materna e, várias vezes, conversamos sobre as possíveis contribuições que estudos como este podem trazer para descrição e compreensão de fenômenos da Libras.

Todo o momento de gravação ocorreu de maneira individual. Nossos colaboradores não receberam material traduzido para Libras. Após a observação das imagens ou textos escritos, eles mesmos traduziam para a Libras. Ao surgir qualquer dúvida, apenas solicitávamos que sinalizassem o que haviam compreendido.

Após a gravação dos vídeos, o material foi analisado no Elan, as imagens previamente selecionadas foram editadas no programa Coreldraw, para a formatação das imagens que, na sequência, foram inseridas no Word, para compor o trabalho.

\subsubsection{Uso do software Elan}

O Elan (EUDICO - Anotador Linguístico) é uma ferramenta amplamente utilizada entre os pesquisadores das línguas de sinais. Utilizamos esse software em nosso estudo por nos permitir visualizar, editar, além de permitir criar e procurar anotações através dos dados dos vídeos. A ferramenta foi desenvolvida no Instituto de Psicolinguística Max Planck, Nijmegen, na Holanda. Pode ser baixado gratuitamente na internet (https://tla.mpi.nl/tools/tla-tools/elan/) e nos permite criar anotações complexas sobre os recursos de áudio e vídeo. 
Com as filmagens gravadas e inseridas no Elan, foi possível analisar minuciosamente a realização de cada sinal e recorremos, várias vezes, ao recurso de diminuir a velocidade, com o objetivo de captar detalhes pormenores, o que facilitou, por exemplo, verificar movimentos e expressões que outros programas não permitiriam.

McCleary, Viotti e Leite (2010, p. 276) elencam alguns motivos para justificar a escolha do Elan como ferramenta em estudos de línguas de sinais:

\begin{abstract}
i) ser especificamente desenvolvido para descrição e análise linguísticas multimodais; ii) estar sendo amplamente utilizado por pesquisadores de várias línguas, em particular de línguas de sinais; iii) estar sendo constantemente atualizado por meio de novas versões que corrigem problemas e introduzem novos recursos; iv) ser disponibilizado gratuitamente; v) ser compatível com PC; vi) possibilitar o uso de arquivos de vídeo e áudio, o que é importante para transcrição e análise de interação bimodal surdo-ouvinte, bem como para os estudos da gestualidade.
\end{abstract}

Diante dessas características, o Elan passou a ser nossa primeira opção de ferramenta para análise dos dados.

\title{
4.4. Considerações do capítulo
}

O presente capítulo apresentou a metodologia percorrida para a captação do corpus. Inicialmente, foram apresentados, na primeira seção, a formação do grupo que constituiu nossos colaboradores surdos e uma explanação sobre os roteiros (ilustrados e escritos) mostrados a eles para a produção dos dados em Libras. Na seção seguinte, sobre a gravação dos vídeos, pudemos observar como ocorreu o processo de filmagem, sempre de forma individual e sem interferência do pesquisador. E, na última seção, o uso do software Elan foi justificado por conter a capacidade de análise minuciosa que a pesquisa necessita. No próximo capítulo, serão apresentados os dados, acompanhados de nossas análises. 


\section{CAPÍTULO 5 - CAUSATIVIDADE EM LIBRAS}

\subsection{Introdução}

Como mencionado nos capítulos anteriores, as construções causativas em línguas orais tornaram-se objeto de pesquisa amplamente estudado por autores como Comrie (1981), Givón (1984), Shibatani (2000), Shibatani \& Pardeshi (2002), e outros. Se observar como, nas línguas orais, predicados de efeito e de causa se associam e se ajustam de acordo com a intenção do falante já é uma tarefa desafiadora, o que esperar de um enunciado assim em Libras? Como é trazer à cena o controlador, ou melhor, o superagente? A estratégia utilizada para aumentar a valência já observada nas línguas orais aplica-se na Libras de forma natural?

Neste capítulo, como já explanado na metodologia, analisaremos os dados coletados durante a pesquisa, observando a relação causa/efeito em sentenças mais (ou menos) diretas, a partir de cena discursiva criada por nós. Vejamos o que revelam nossos dados.

\subsection{Análises e resultados versus a literatura corrente}

No capítulo referente à metodologia, explanamos sobre a coleta dos dados e a sua origem. O estudo foi organizado a partir de: i) roteiros ilustrados e, na sequência, ii) roteiros escritos. Pedimos aos colaboradores surdos que, após observarem cada uma das ilustrações, sinalizassem em Libras. Torna-se importante ressaltar que cada um dos colaboradores observou a ilustração e realizou a filmagem da tradução para Libras de forma individual. Os colaboradores não tiveram contato uns com os outros durante o processo de filmagem.

Para melhor visualização e análise dos dados, apresentaremos as imagens da tradução em Libras, realizada por cada um dos colaboradores, seguida do sinal correspondente em caixa alta, que será traduzido de forma literal para só então fazer uma tradução aproximada da língua portuguesa, conforme descrito na metodologia. 
O primeiro roteiro ilustrado era composto por uma sequência de três imagens ${ }^{20}$ :

Imagem 1

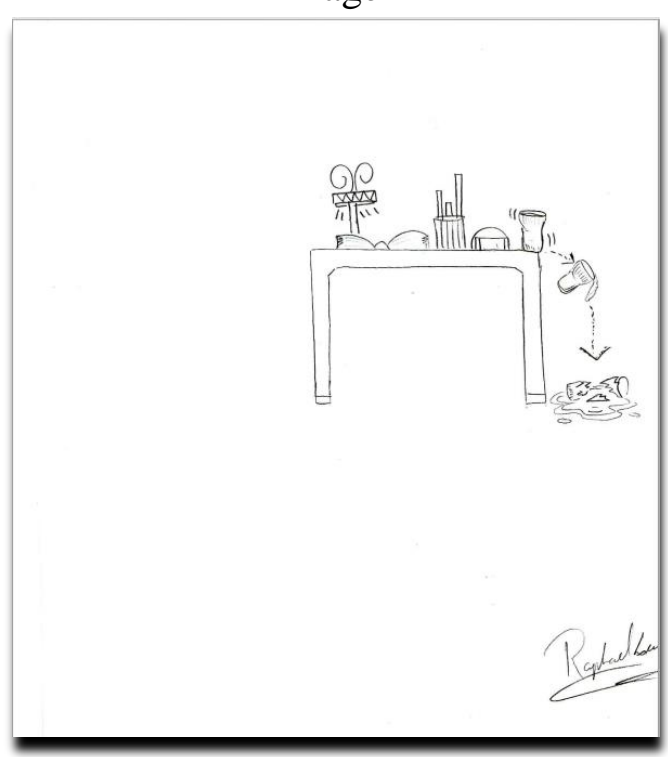

Imagem 2

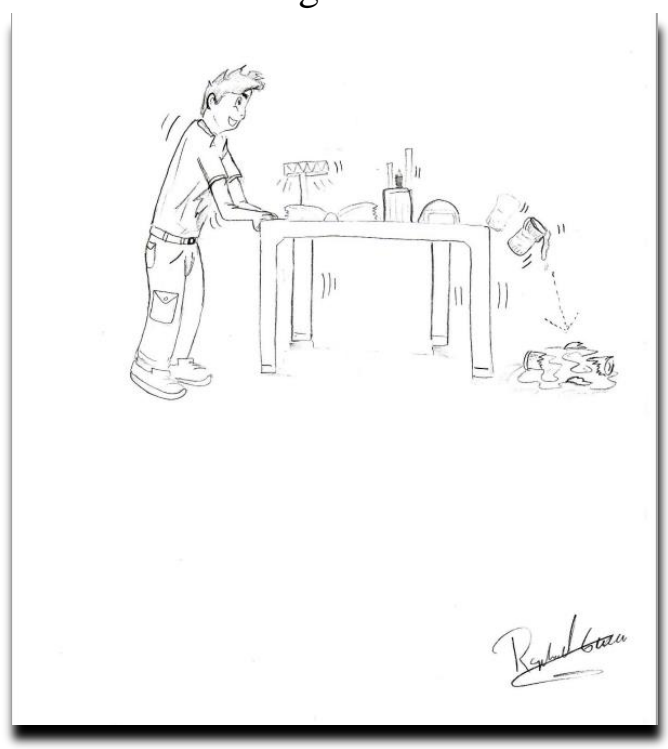

Imagem 3

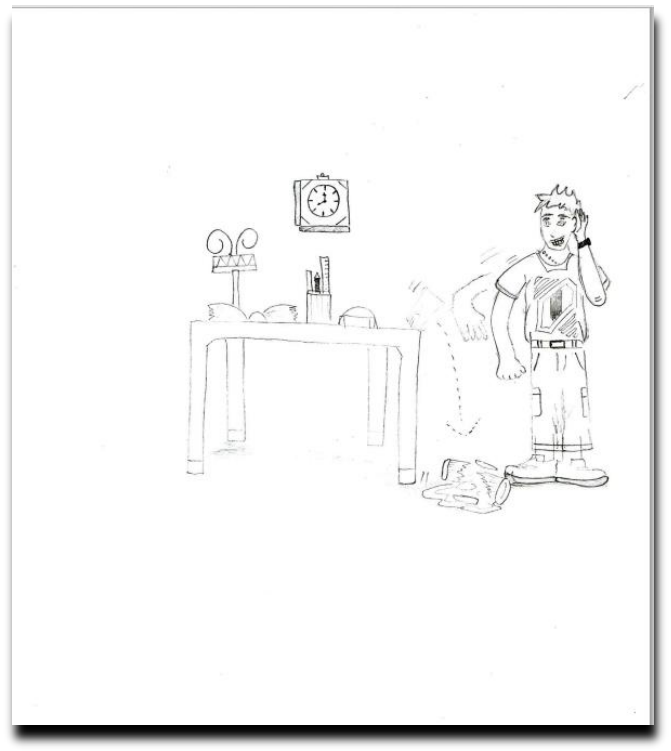

Esperávamos que, ao observar as imagens, os colaboradores, em Libras, se aproximassem de uma tradução em português, de:

Imagem 1 - O copo quebrou.

\footnotetext{
${ }^{20}$ Para facilitar a leitura, tornando-a mais didática, consideramos pertinente reapresentar as imagens do roteiro ilustrado neste capítulo.
} 
Imagem 2 - O menino fez o copo cair.

Imagem 3 - O menino derrubou o copo.

Vejamos como nossos colaboradores produziram em Libras as sentenças apresentadas na sequência das imagens.

O primeiro colaborador, após observar a primeira imagem, sinalizou:

1) O copo quebrou.
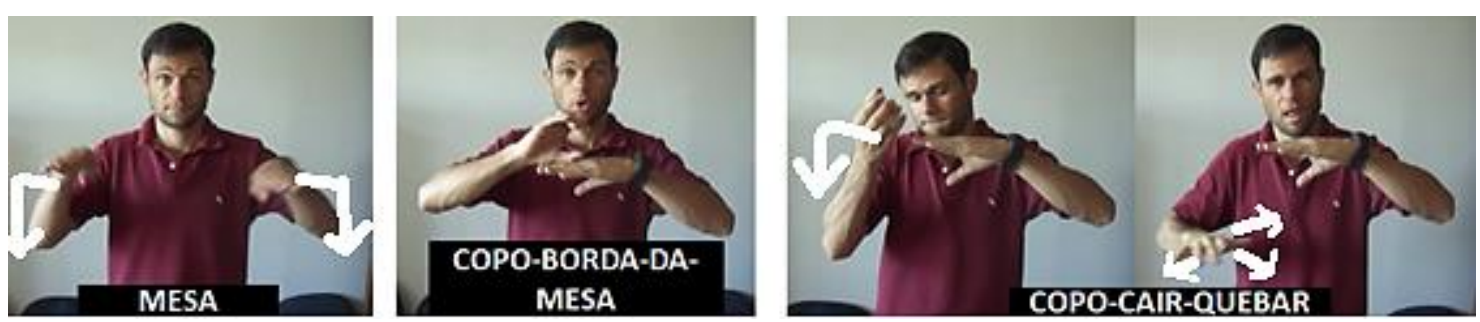

"Havia na borda da mesa um copo. Daí ele caiu e quebrou."

Percebemos que ele trouxe os referentes para cena e descreveu a ação. Como resultado, tivemos uma descrição literal da cena. O colaborador, somente depois de descrever todo o cenário (a mesa, o copo, a localização do copo) utilizou-se da expressãonão-manual (com o movimento da boca) e a mão espalmada (cf. quadro 3) para apresentar "o copo quebrou".

Na sequência, ao observar a ilustração de número 2 ( $O$ menino fez o copo cair $)$ o colaborador traduziu:
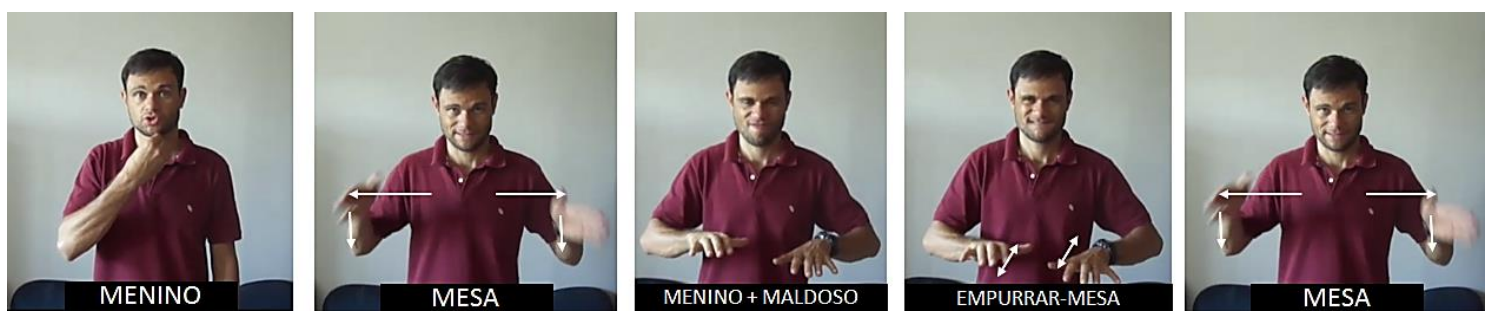

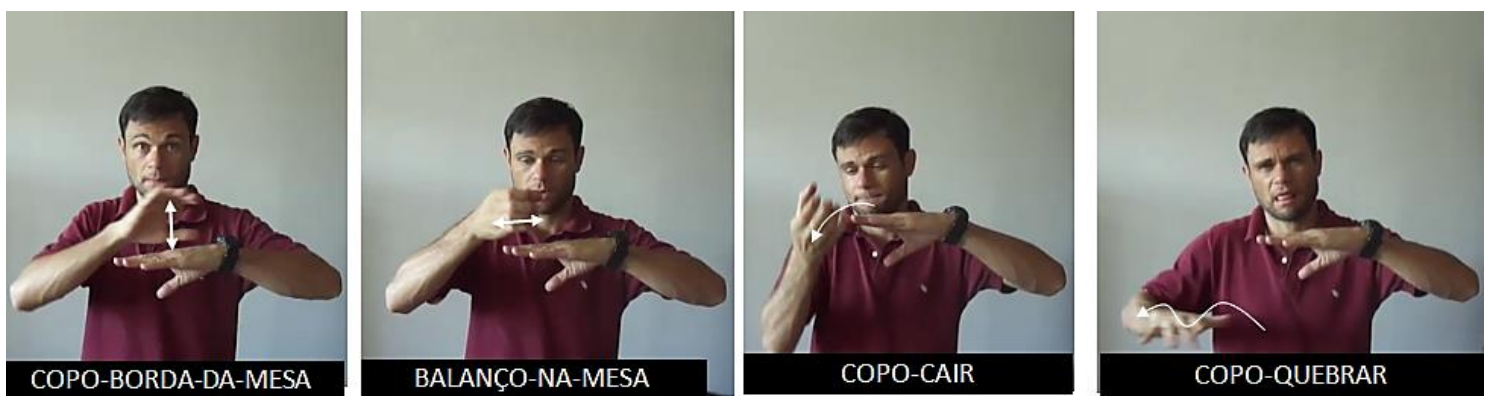

"Um menino empurrou a mesa maldosamente; na borda dela havia um copo; o balanço da mesa fez o copo cair e quebrar".

Com o acréscimo de um "causador" à cena discursiva, é possível perceber que o colaborador introduz o sujeito agente no início da oração, porém o objeto paciente (o copo) entra em cena somente depois da descrição do cenário. O colaborador, após observar o desenho, registra em Libras, através do item lexical, traduzido em português por maldade, que a ação foi proposital como se quisesse afirmar que o menino, agente prototípico, aquele que controla a ação e ao mesmo tempo é o causador, por promover a mudança no objeto causado, é o principal responsável pela realização do evento.

Na terceira e última cena, $O$ menino derrubou o copo, o colaborador após observar a ilustração sinalizou em Libras:
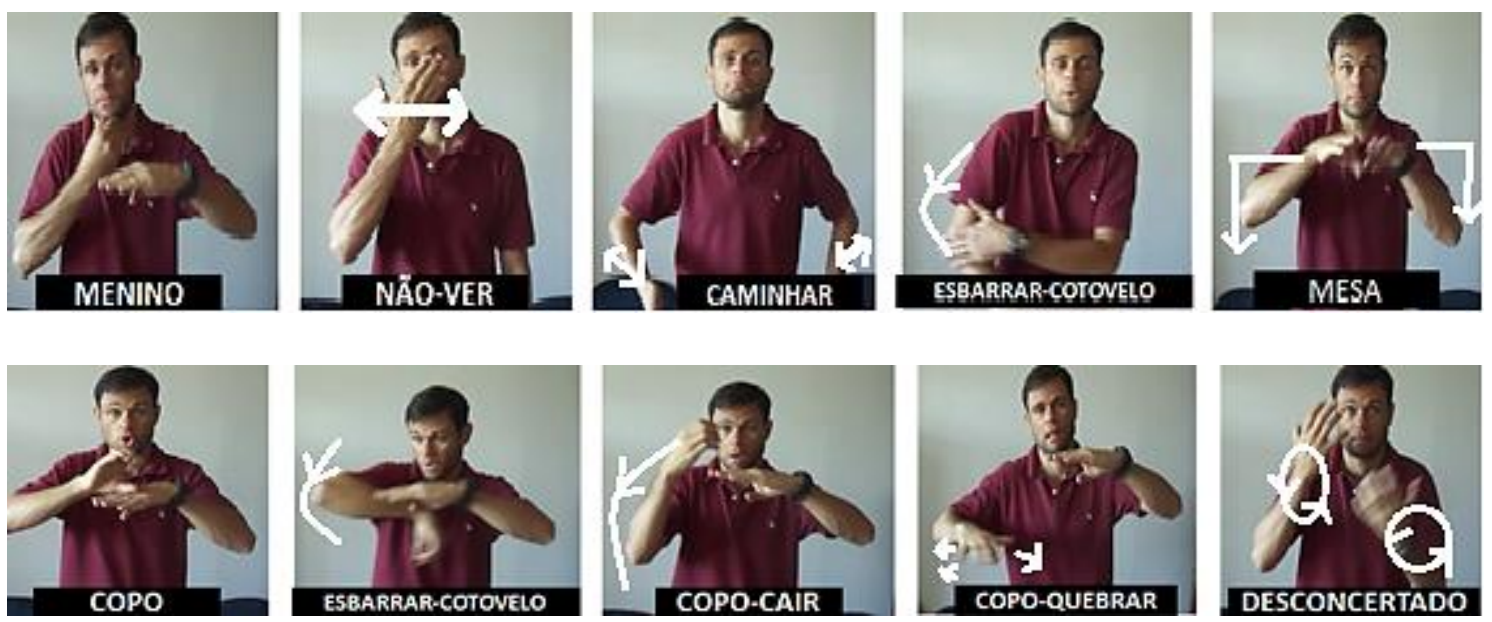

“O menino, sem perceber, enquanto caminhava, esbarrou o cotovelo no copo que estava na borda da mesa. O copo caiu e quebrou, e ele ficou muito desconcertado." 
Assim como no enunciado 2, no enunciado de número 3, aumentou-se a valência ao acrescer um causador/controlador à cena discursiva. Apesar do colaborador traduzir dois enunciados distintos (sentenças 2 e 3) para o mesmo efeito o copo quebrar, o verbo “cair” não sofreu alteração morfológica ou lexical. Parece que estamos diante de uma causativa perifrástica. Mas qual seria a diferença entre 2 e 3 ? Segundo Givón (1984), se uma língua tem mais de um tipo formal de causativa, o menor será usado para expressar causação direta. Logo, o enunciado 3 poderia ser considerado mais direto que o enunciado 2 justamente por ter um pouco menos de material linguístico. Observemos outro colaborador para analisar o postulado de Givón, na Libras.

A colaboradora a seguir observou o mesmo roteiro ilustrado acima. Após observar atentamente o desenho no papel, ela perguntou como o copo havia caído: uma pessoa havia entrado na sala e mexido na mesa? O vento? Como poderia um copo cair? Pedimos que ela apenas traduzisse para Libras, e o resultado foi:
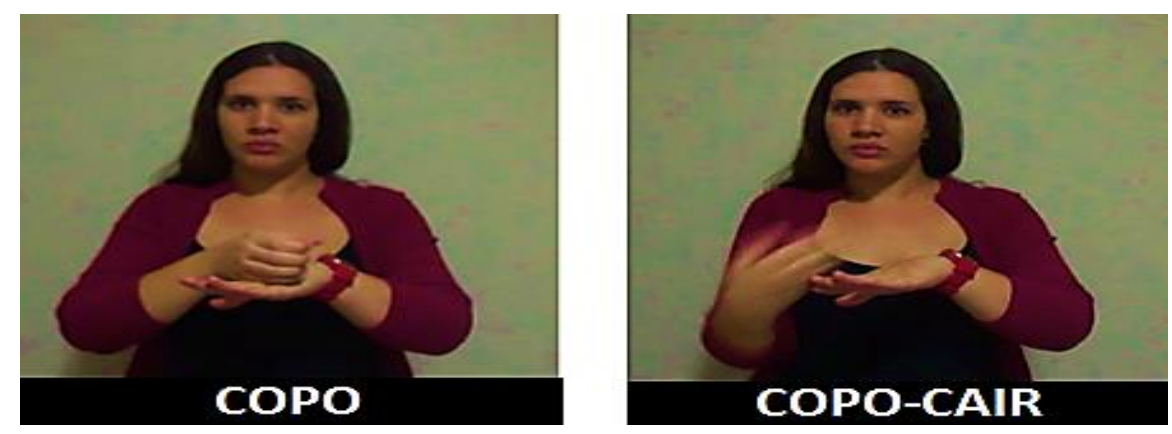

"O copo caiu."

Diferentemente do dado apresentado pelo primeiro colaborador, a sentença não apresenta a riqueza de detalhes como a mesa, a localização do copo na mesa, o cair e quebrar do copo. Ainda assim, a mensagem foi transmitida, a sentença é gramatical. Um fato curioso surgido no momento da gravação foi da surda optar em construir o enunciado utilizando apenas dois sinais cuja ordem é SV, percebemos a intransitividade do verbo CAIR, também na Libras. Outro aspecto observado é de que, embora o copo assuma a RG de sujeito, tem a função semântica de ser paciente e talvez daí tenha causado estranhamento à colaboradora. No estudo da Libras, ao apresentar a particularidade da modalidade visuoespacial das línguas de sinais, é possível perceber que há a necessidade de posicionar todos os referentes no espaço para descrição de uma cena. Em algumas 
línguas orais, como o Português, por exemplo, a topicalização do paciente pode ser considerada como um recurso de rebaixamento e até apagamento do agente, de acordo com a intenção do falante. Após analisar os dados dos colaboradores 1 e 2, ficou evidente que a Libras não utiliza desse recurso, possivelmente por ser visual, afinal, há a necessidade de explicitar a ação: Quem é o causador?

Ao observar a segunda imagem cuja tradução aproximada em português seria $O$ menino fez o copo cair, a colaboradora sinalizou:
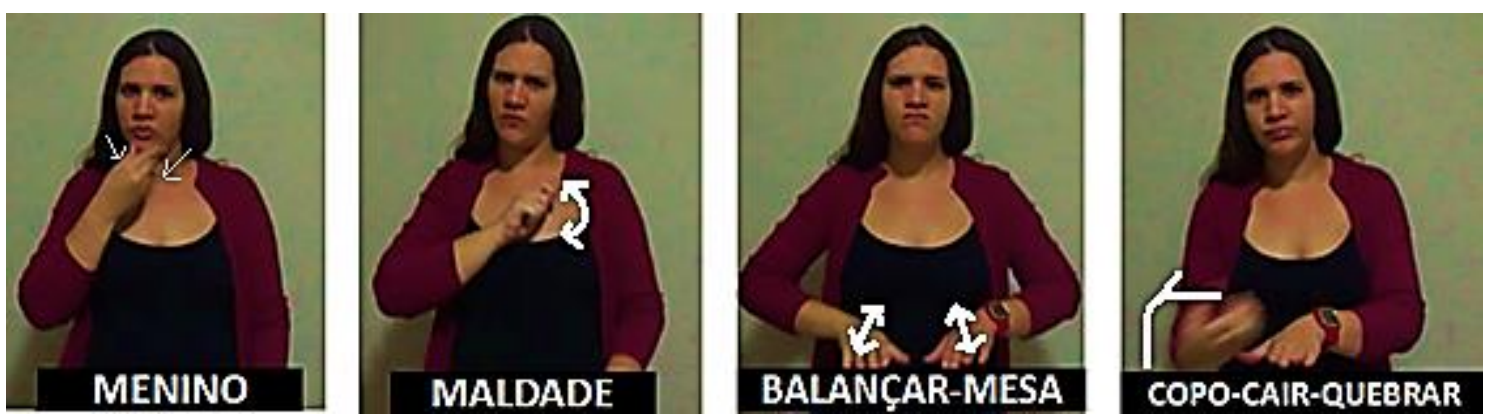

"O menino, maldosamaente, balançou a mesa, e o copo caiu e quebrou."

De forma muito semelhante ao colaborador 1, a colaboradora 2 traz à cena 0 "causador/causa" O menino que balança a mesa e o "causado/efeito" o copo caído e quebrado. Novamente, o sinal de maldade está presente na cena discursiva. Nesse contexto, é possível inferir que o sinal MALDADE aparece no discurso para evidenciar um processo volitivo. Há a intenção de derrubar o copo, e a Libras utiliza-se desse sinal para remeter tal prototipicidade semântica do agente menino (tem volição, animacidade, o controle da ação - é ele o responsável em iniciar a ação e promover a mudança do paciente, o copo).

Na terceira e última imagem do roteiro ilustrado, em que teríamos como tradução aproximada $O$ menino derrubou o copo, a surda sinalizou:
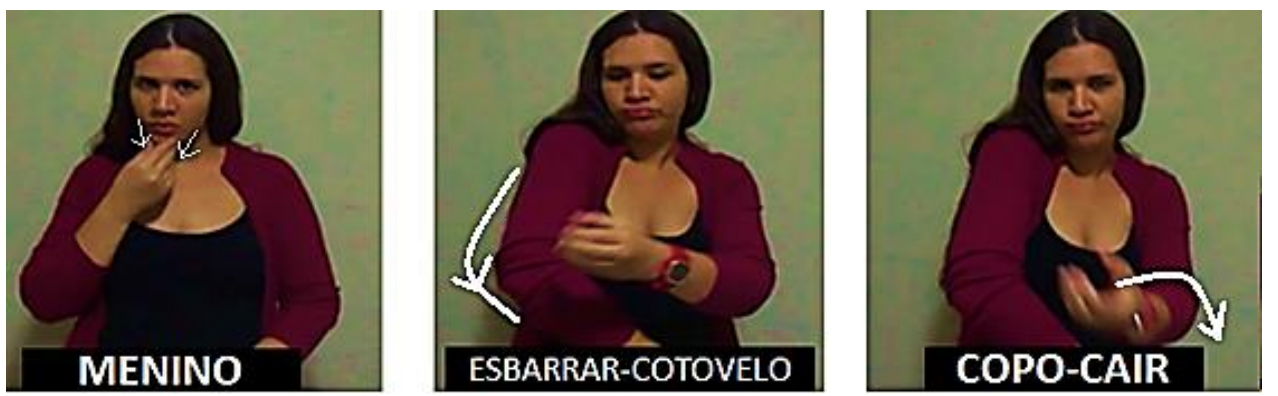

"O menino derrubou o copo sem querer." 
Ao compararmos a sentença 3 com a sentença anterior, é possível perceber que os itens lexicais (sinais) utilizados na sequência 2 tornaram a construção causativa mais indireta, talvez pelo próprio sinal MALDADE. O mesmo roteiro foi apresentado a outros colaboradores, e respostas muito semelhantes foram apresentadas em Libras. Precisávamos encontrar uma outra estratégia para apresentar os dados aos nossos colaboradores e nos certificar dessas hipóteses: 1) há causativa perifrástica em Libras e 2) a causativa mais curta traduz um evento mais direto.

Conforme exposto no capítulo 4, criamos um novo roteiro, composto por um curto texto escrito e uma sequência de três cenas ilustradas para serem apresentadas aos nossos colaboradores.

Roteiro 2

O menino não gosta de maçã. O menino
está doente e precisa de uma alimentação
saudável. A mãe do menino manda que
ele coma a maçã. Ele não quer comer a
maçã. A mãe orienta o menino para que
ele coma a maçã.

Imagem 1

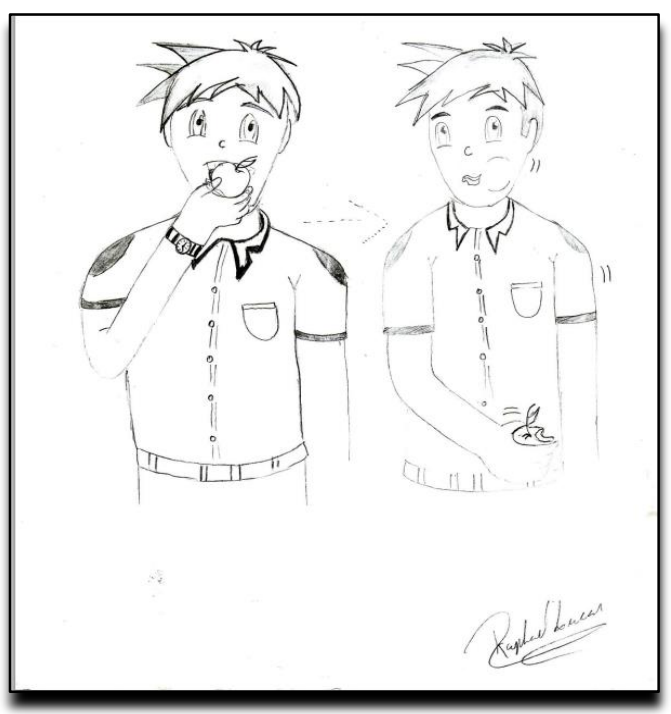

Imagem 2

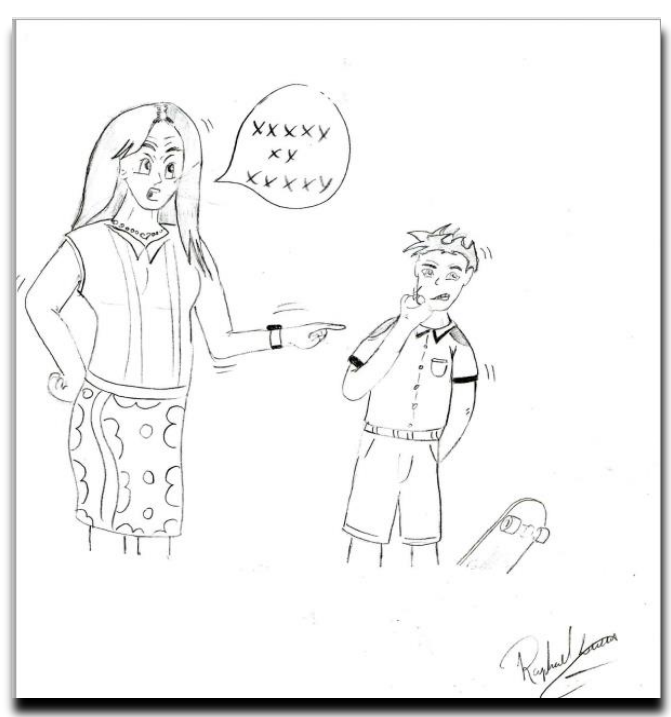


Imagem 3

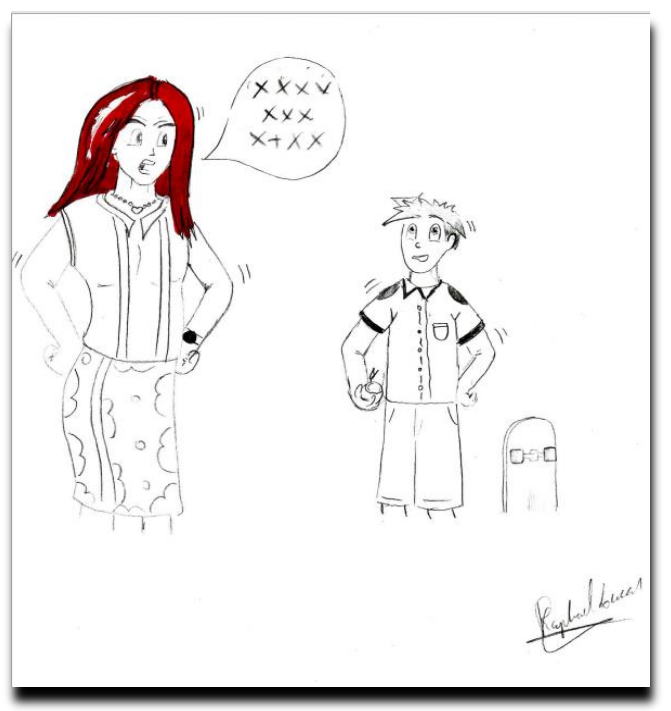

Cada um dos colaboradores leu o texto, observou as 3 imagens e traduziu para Libras. Esperávamos como tradução aproximada, em português:

4) O menino comeu a maçã.

5) A mãe fez/obrigou o menino comer a maçã.

6) A mãe orientou o menino a comer a maçã.

O primeiro colaborador, após a leitura do texto e a observação da primeira imagem, traduziu para Libras:
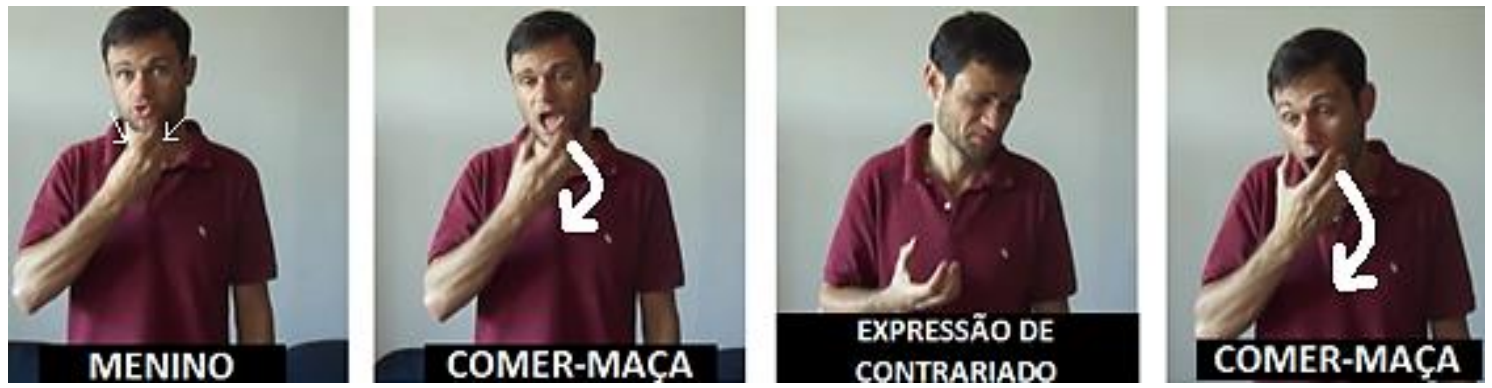

"O menino comeu a maçã contrariado."

Ao observar a sentença, percebemos que, apesar da ordem SVO, o colaborador enfatiza a ação de comer a maçã na expressão (ao mostrar que está contrariado) e, para dar continuidade à sentença, apresenta novamente o verbo e o objeto direto (em composição, cf. capítulo 2). Segundo Quadros \& Karnopp (2004), a duplicação de partes 
do discurso, como ocorre com o colaborador, são construções com foco, porque tem como objetivo duplicar o elemento merecedor de destaque, na posição final.

Em seguida, na segunda cena, A mãe fez/obrigou o menino comer a maçã, o colaborador depois de observar atentamente o desenho, traduziu para Libras:
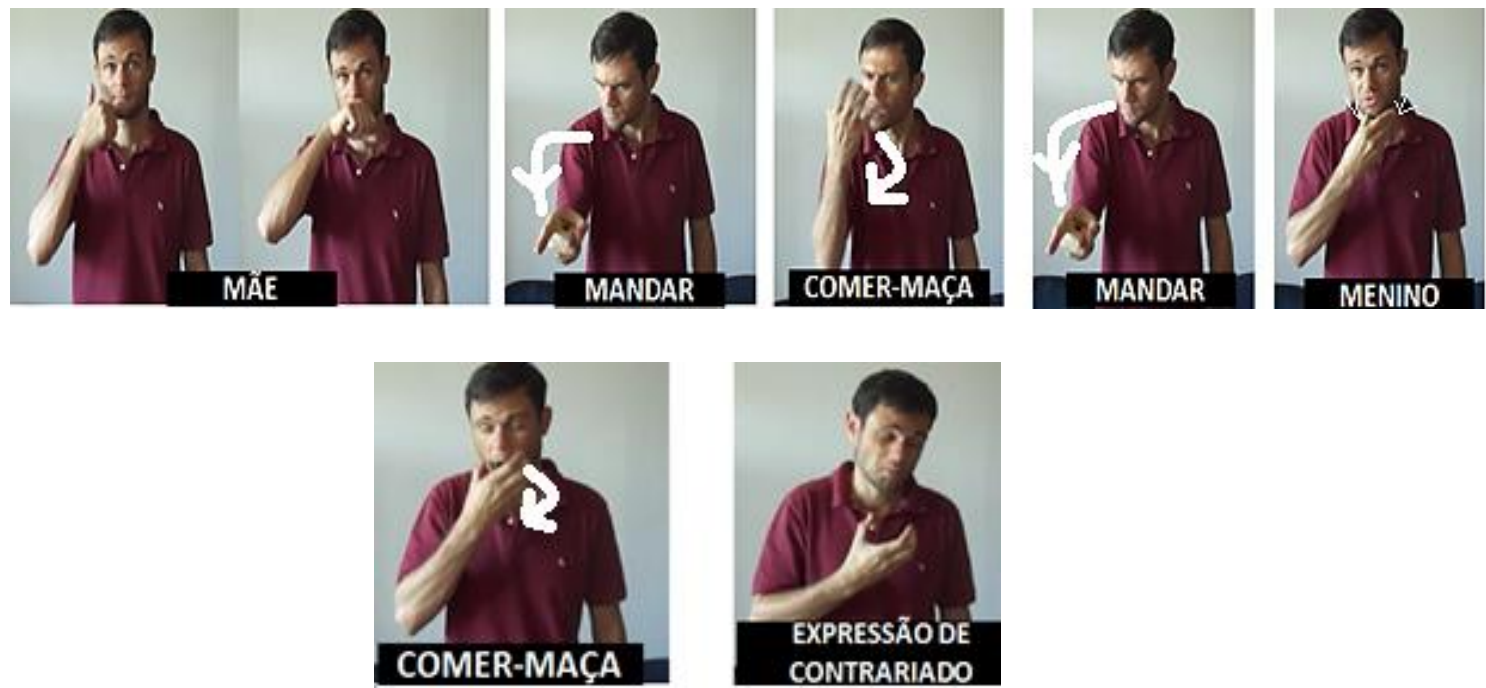

"A mãe mandou o menino comer a maçã, e ele comeu contrariado."

O enunciado produzido pelo colaborador na primeira sentença mais uma vez aparece na sinalização, porém, acrescido de um causador "A mãe mandou comer maçã, mandou no menino". Percebemos que a construção em Libras aproxima-se da expressão em português como se disséssemos: A mãe fez/obrigou o menino comer a maçã. Observamos claramente a existência de:

C) Uma causa: A mãe fez/obrigou

D) Um efeito: o menino comer a maçã.

É importante ressaltar que a força do superagente (a mãe) é tão relevante que ele aparece duas vezes na primeira oração da sentença A mãe mandou comer maçã [a mãe] mandou [o menino... ]. Isso pode ser percebido no sutil deslocar do tronco do sinalizante para a direita, conforme os quatro primeiros quadros da tradução. 
No último quadro da cena, o colaborador observou o desenho, perguntou qual era a diferença entre este quadro 3 e o anterior (quadro 2). Solicitamos que ele sinalizasse em Libras o que havia compreendido, inclusive como diferença entre as cenas. O colaborador reclamou do desenho e disse não perceber diferença. Então conversamos sobre a autoridade da mãe e o papel de orientar os filhos para uma alimentação saudável. Ele perguntou se o menino do desenho estava doente e criamos uma situação hipotética que, além de estar doente, o menino precisava comer a fruta mesmo sem vontade. $\mathrm{O}$ resultado em Libras foi:
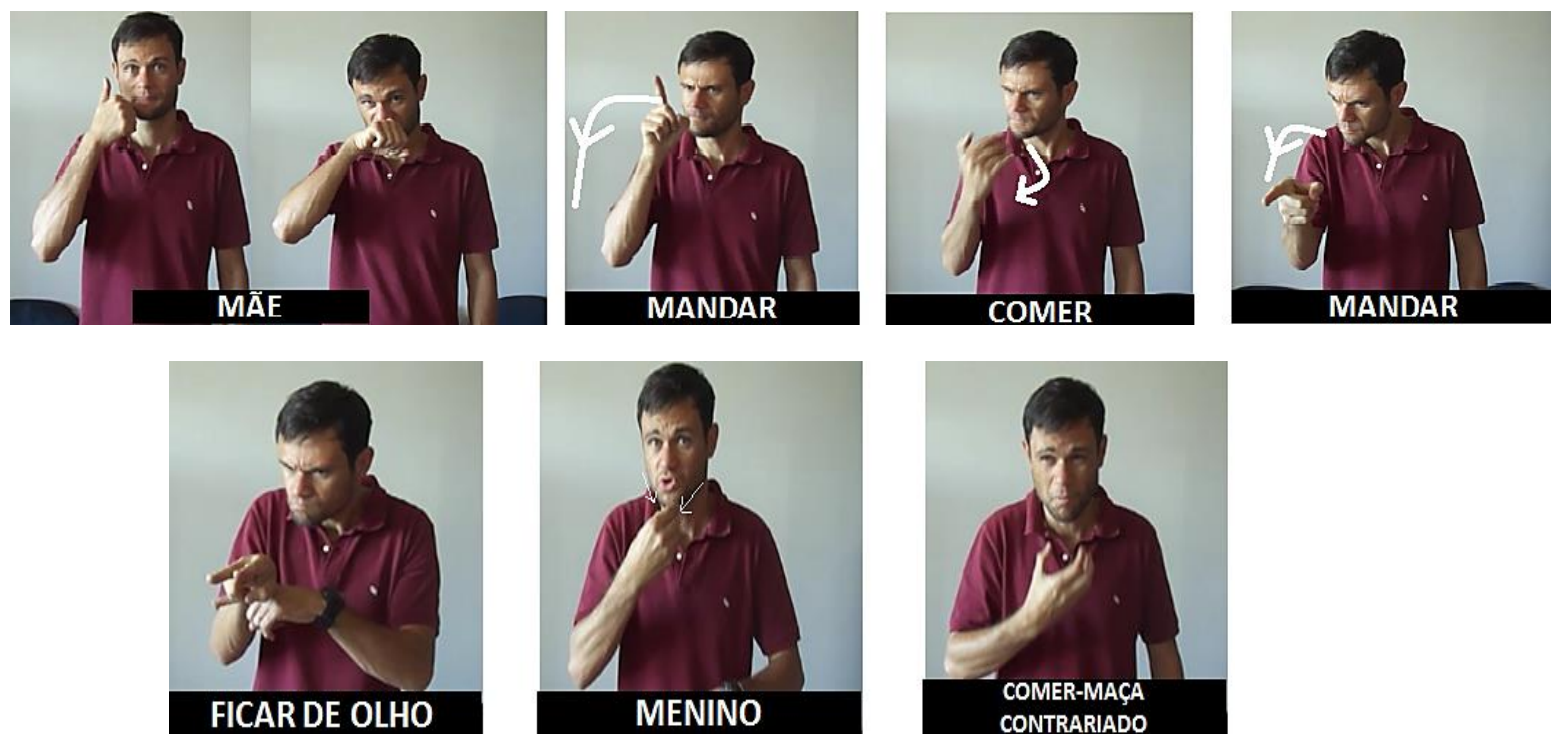

"A mãe mandou o menino comer maçã e ficou observando para vê-lo comer. O menino comeu a maçã contrariado.”

Analisando o enunciado do colaborador surdo, é possível perceber que um predicado de causa (a mãe mandou) é associado ao predicado de efeito (o menino comer a maçã). Embora tenha surgido uma nova informação ( $A$ mãe observar o menino, para certificar-se de que ele comeu) a estrutura causativa criada é muito semelhante à construção anterior e talvez essa informação tenha surgido somente em virtude da conversa que tivemos no momento em que o colaborador perguntou qual seria a diferença entre os dois desenhos. Ao analisar os constituintes, mais uma vez é possível perceber a importância do superagente mãe: i) A mãe manda comer; ii) [a mãe] manda e; [a mãe] fica de olho. A mãe é o superagente controlador das três ações enquanto o sujeito menino até o momento é apresentado como objeto dos verbos anteriores. Somente no final da 
sentença, o menino torna-se sujeito $\boldsymbol{O}$ menino comeu a maçã contrariado. Ora, se o menino é apresentado em três momentos distintos como objeto e apenas uma vez como sujeito da oração é possível perceber que existe similaridade na construção causativa da Libras com outras línguas orais.

Seguindo Comrie (1981), temos no enunciado produzido uma clássica causativa perifrástica em que o agente (ou causa) age sobre outro agente, o menino, o qual, por sua vez, desencadeia um efeito: comer a maçã. Em consonância com Neves (1997), a causativa é considerada perifrástica quando há uma oração principal (A mãe mandou) e uma outra oração, a subordinada (o menino comeu a maçã contrariado). Isso também vai ao encontro do que preveem Shibatani \& Pardeshi (2002) em seu Continuum (cf. seção 3.2.1).

$\mathrm{O}$ mesmo roteiro foi apresentado para nossa segunda colaboradora, $O$ menino comeu a maçã. A surda leu o texto e, na sequência, olhou a primeira imagem e, como resultado, sinalizou:
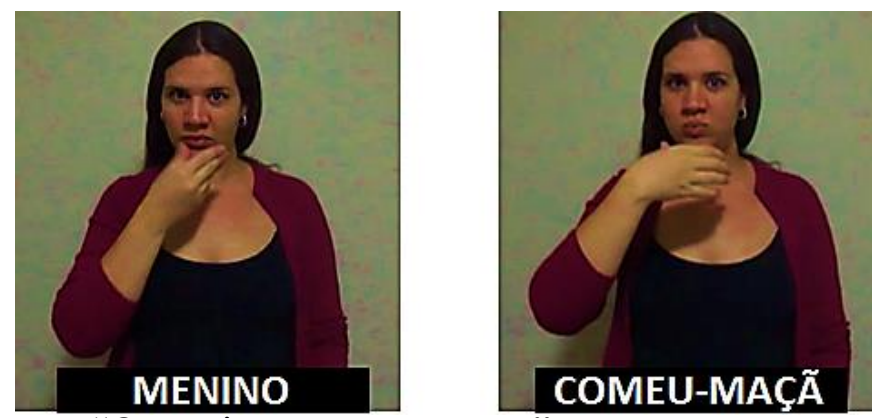

"O menino comeu a maçã."

A ordem também utilizada pelo primeiro colaborador, manteve-se, SVO, porém, diferentemente, não apresenta duplicação de parte do discurso (“cópia”). De forma semelhante, os dois colaboradores fazem a composição verbo-objeto, assim, não existe um sinal para comer e um outro sinal para maçã, como pode ser observado na segunda imagem. Os parâmetros se compõem num único sinal para apresentar verbo e objeto (cf. seção 2.2.1). Observemos o segundo enunciado: 

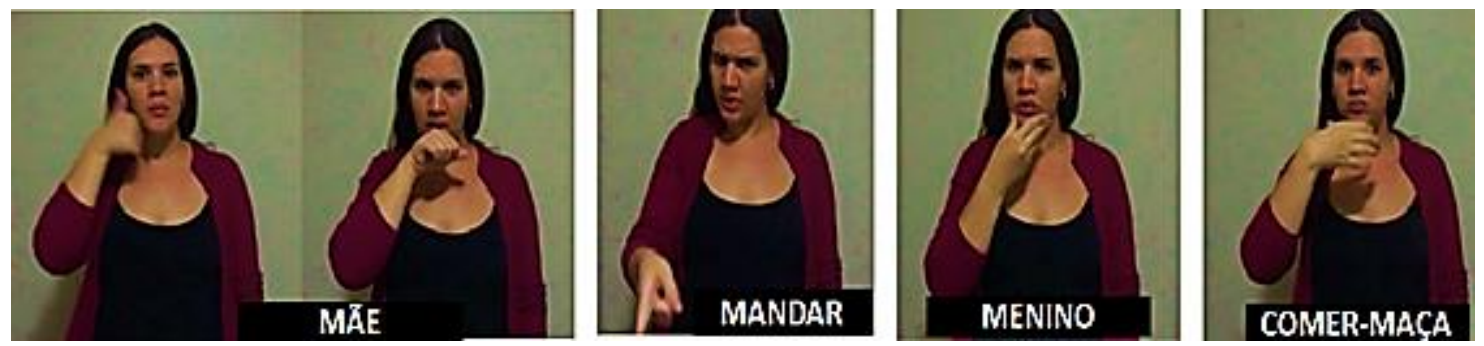

“A mãe fez o menino comer a maçã."

Bem como o primeiro colaborador, percebemos na construção que a surda apresenta uma situação composta de dois eventos em que há um causador e um causado. Ao observar a última imagem do roteiro, a colaboradora afirmou não perceber diferença entre as duas últimas imagens, e a mesma orientação dada ao colaborador anterior sobre a doença do menino e a importância de comer a fruta foi repassada à surda, lembrando que nosso objetivo era conseguir uma tradução aproximada de (em português) $A$ mãe orientou o menino a comer a maçã, e foi exatamente isso que tivemos como resultado:
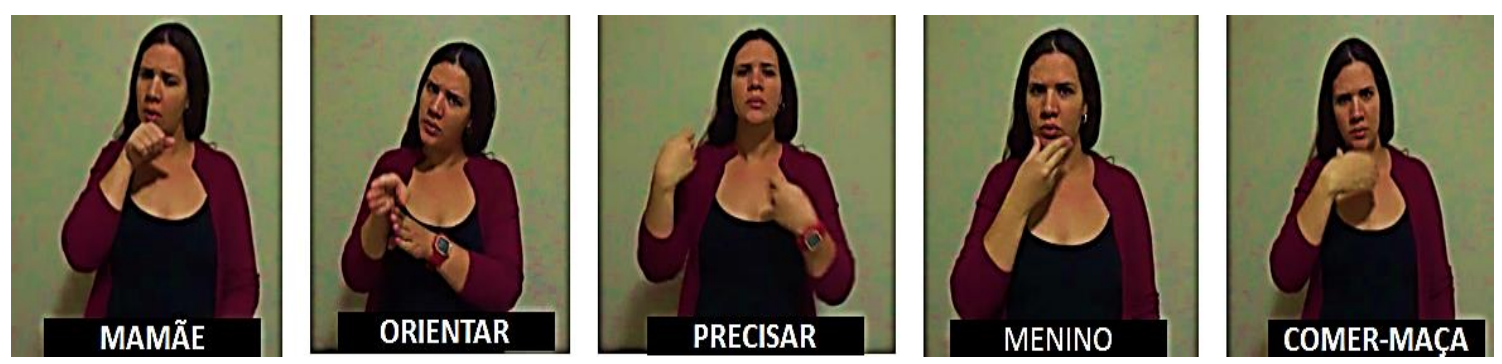

"A mãe orientou que o menino precisava comer a maçã."

O enunciado produzido é uma construção causativa menos direta, pois a mãe apenas orientou o menino. Ao apresentar à sinalizante a importância de uma alimentação saudável mediante o quadro de enfermidade do menino, o sinal de orientar foi utilizado pela pesquisadora durante a elucidação para apresentar "possíveis diferenças" entre as imagens 2 e 3 deste roteiro (cf. seção 4.2). Neste momento, pensamos novamente que talvez tivéssemos de buscar uma outra estratégia de metodologia para a coleta de dados. A ilustração do roteiro 1 ou a ilustração e o texto do roteiro 2 não atenderam plenamente à nossa proposta, conforme descrição no capítulo referente à metodologia. 
Com o roteiro de número 3, sentenças escritas em português foram apresentadas aos colaboradores surdos para que fossem traduzidas para Libras. Após as tentativas com as ilustrações consideramos pertinente realizar o roteiro escrito (sem as ilustrações anteriores), para contrastar com os dados já coletados, além de observar a diretividade das construções causativas em Libras.

A terceira proposta intitulada roteiro escrito continha roteiros com 3 enunciados em português escrito. Sentenças previamente escolhidas foram mostradas aos diferentes colaboradores. O primeiro roteiro apresentado:

4) O cachorro morreu.

5) O menino matou o cachorro.

6) O menino fez o cachorro morrer.

Nosso primeiro colaborador leu o enunciado $O$ cachorro morreu e traduziu para Libras:

\section{"O cachorro morreu."}

Ao ler o segundo enunciado, $O$ menino matou o cachorro tivemos como resultado:
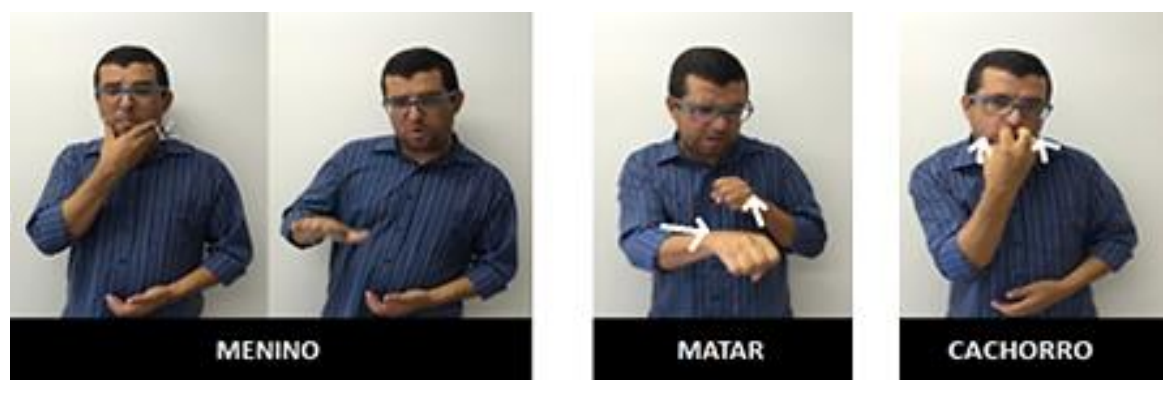

"O menino matou o cachorro."

O causador foi introduzido na cena, o verbo MORRER foi substituído por MATAR e, de maneira muito semelhante ao português, a construção causativa em Libras permanece com a ordem SVO. 
No terceiro enunciado, $O$ menino fez o cachorro morrer, o colaborador surdo sinalizou em Libras:
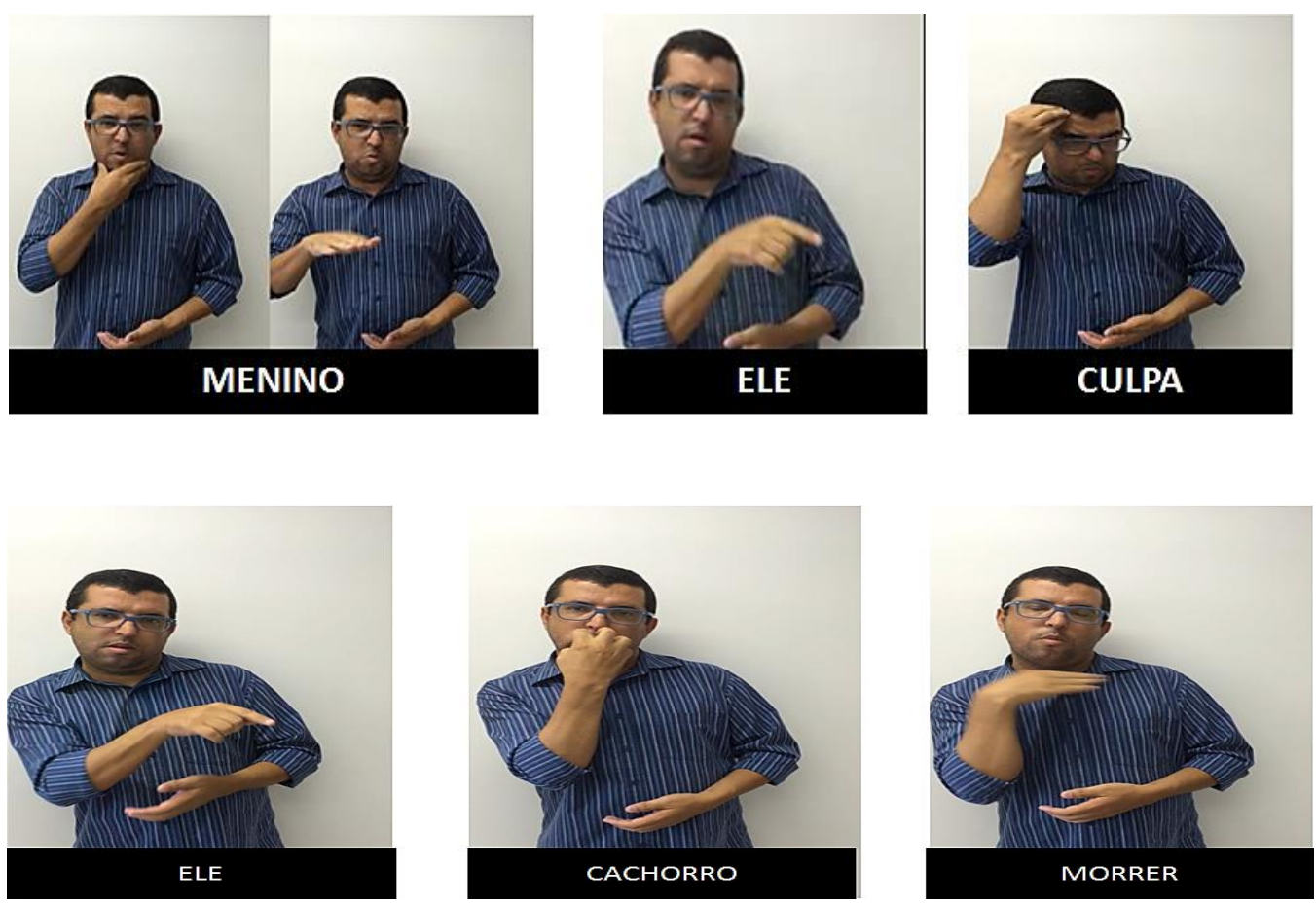

"O menino, por culpa dele, o cachorro morreu ou O menino fez o cachorro morrer de propósito".

Na Libras, é possível perceber claramente o causador e o causado, bem como na sentença anterior, porém chamou-nos a atenção as escolhas lexicais do colaborador para evidenciar a responsabilidade do superagente (o menino) no evento (a morte do cachorro), como se dissesse "O menino, ele o menino, por culpa dele o cachorro morreu." Além de ocupar a posição de maior destaque, o causador é citado 3 vezes na mesma sentença. Neste primeiro momento, ao observar as duas sentenças produzidas, pelo mesmo colaborador, (para tratar da morte do cachorro) percebemos que as duas sentenças na Libras são diretas, mas a sentença 2 é mais direta que a 3, o que torna 3 mais parecida ainda com a sentença 3 em Português. O sujeito do evento de causa age menos diretamente sobre o sujeito do evento causado, talvez porque somado a isso, aparece o sinal de CULPA, como nos primeiros dados analisados acima, em que aparece o sinal de MALVADO em enunciados com menor diretividade. Talvez não seja só uma questão de 
maior ou menor diretividade, mas de maior ou menor culpa/responsabilidade. Assim quanto mais culpa/responsabilidade, maior é a sentença, maior é a expressão de causatividade. Isso seria algo a se acrescentar às pesquisas tipológicas sobre causatividade: quanto mais material linguístico, maior a responsabilidade do superagente, mesmo que haja menos diretividade na ação.

Vejamos o mesmo roteiro com outro colaborador surdo:

Ao ler a sentença $O$ cachorro morreu, a colaboradora surda sinalizou:
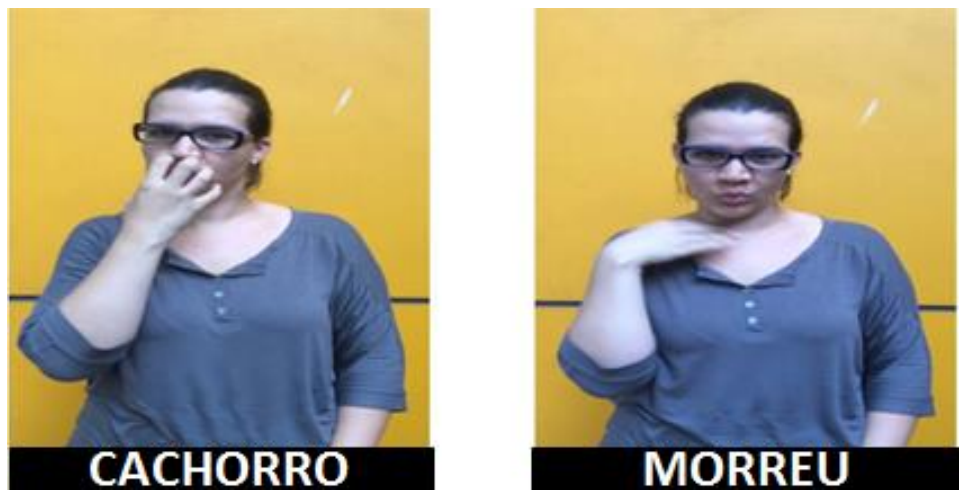

"O cachorro morreu."

Assim como o primeiro sinalizante, a surda fez a tradução literal do enunciado escrito, que é também utilizado em Libras. Na sentença seguinte $O$ menino matou $o$ cachorro, observamos a mesma tradução do primeiro colaborador:
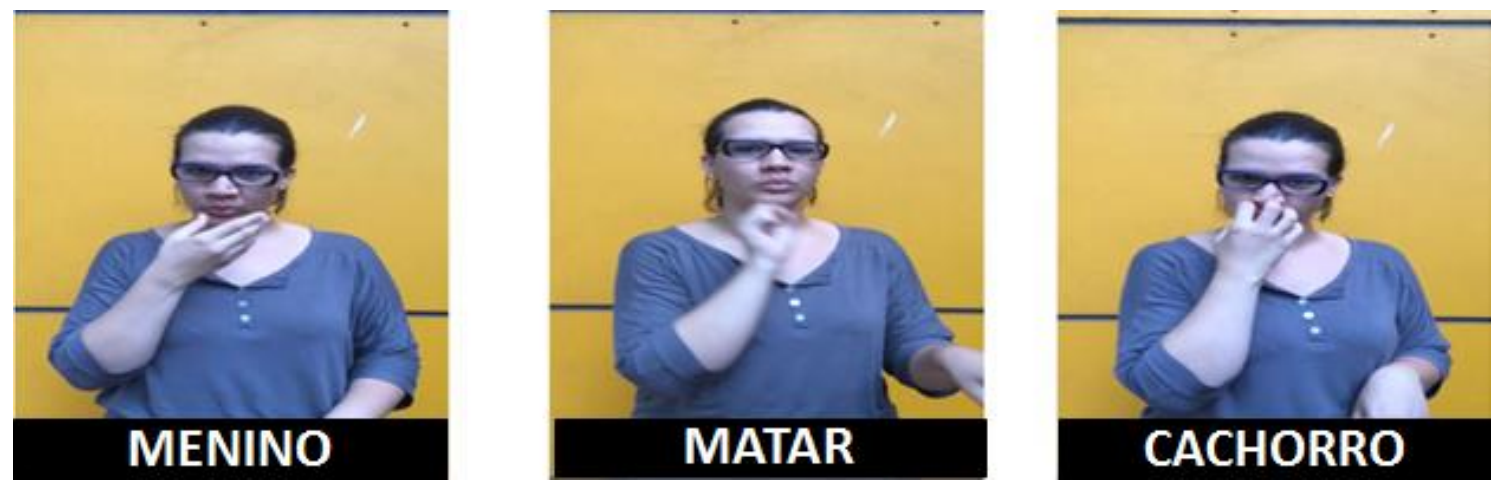

"O menino matou o cachorro."

E, na sequência, para o último enunciado A menina fez o cachorro morrer, a surda sinalizou: 

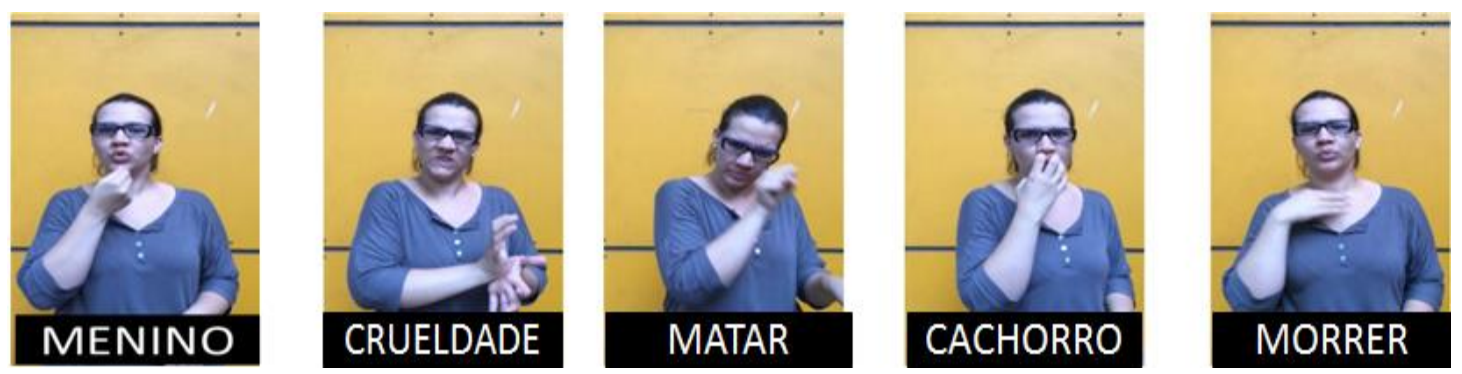

"O menino com crueldade matou o cachorro e ele (o cachorro) morreu.

Temos uma construção causativa que, diferente da sentença anterior, agrega uma nova característica ao superagente enquanto controlador pleno e consciente, o que é possível perceber no sinal CRUELDADE. O sinal CRUELDADE em Libras apresenta uma carga semântica para atribuir mais volição à ação.

Analisando ainda esta última sentença, notamos que a colaboradora delimita claramente a relação de causa-efeito ao apresentar distintas expressões-não-manuais ao sinalizar os verbos MATAR e MORRER. No sinal MATAR, a surda projeta a cabeça sutilmente para baixo e realiza uma expressão com as sobrancelhas, diferentemente da expressão utilizada ao realizar o verbo MORRER, em que a cabeça retorna a posição inicial e no rosto, a expressão de descontentamento. Percebemos mais uma vez a necessidade que a língua apresenta de explicitar a ação, e, é essa particularidade na Libras que anuncia a crueldade do menino em matar e, o efeito, a morte do cachorro. Percebemos, mais uma vez, que uma maior volição do superagente causador é expressa por um sinal específico, agora o sinal CRUELDADE e que o enunciado é maior que o enunciado sem essa volição explícita (enunciado 2).

O colaborador seguinte leu o enunciado $O$ cachorro morreu e traduziu:
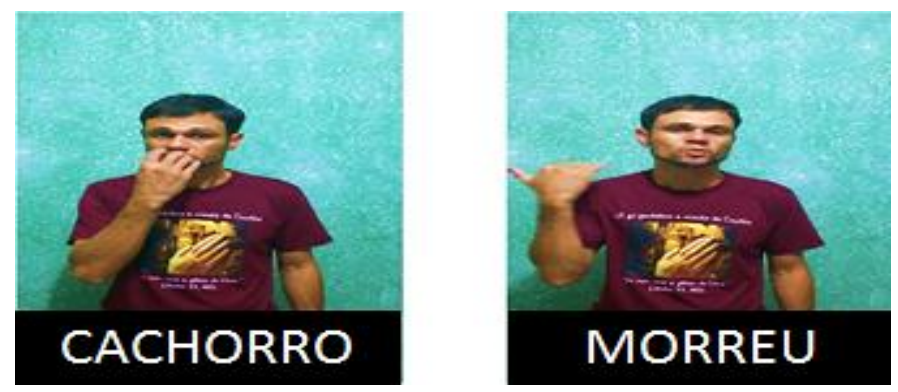

"O cachorro morreu" 
Igualmente aos colaboradores anteriores, a mesma tradução, assim como também ocorreu na sentença seguinte $O$ menino matou o cachorro:
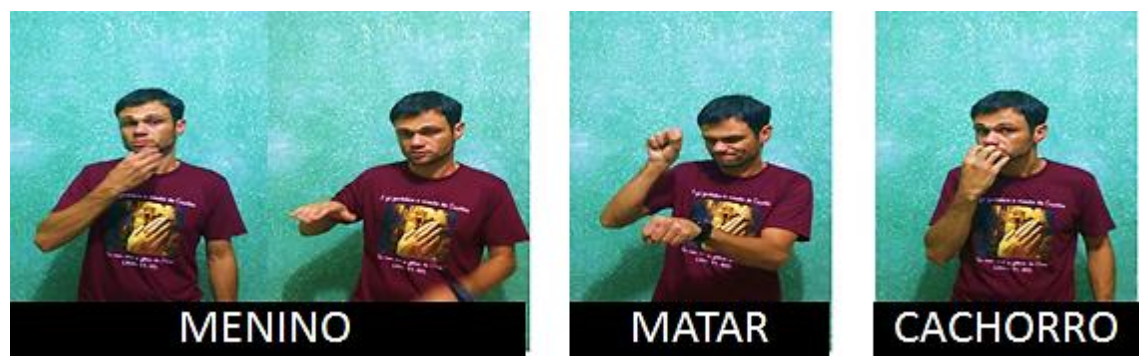

"O menino matou o cachorro."

Ao ler a última sentença, "o menino fez o cachorro morrer”, o colaborador surdo produziu em Libras:
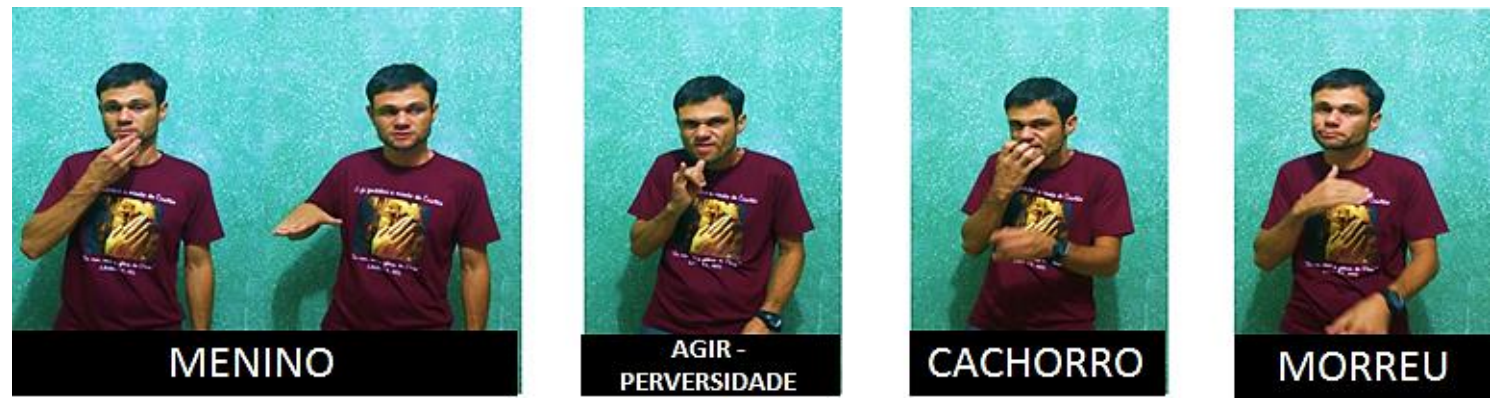

"O menino agiu perversamente com o cachorro, e ele [o cachorro] morreu."

O causador é trazido à cena e uma nova informação é acrescida à sentença: $a$ ação perversa do menino. Embora não haja um sinal explícito para evidenciar como ocorreu a morte do cachorro, infere-se na expressão-não-manual associada ao sinal AGIRPERVERSIDADE que é ele, o superagente (O menino), o responsável pelo desfecho da ação, facilmente percebível na posição de destaque, que é a posição inicial do enunciado. O colaborador, em consonância com outros colaboradores, evidencia a intencionalidade do causador, tornando a ação ainda mais volitiva, quando contrastada, por exemplo, com o enunciado 2 anterior.

Analisando os três enunciados deste primeiro roteiro escrito, foi possível perceber que todos os colaboradores organizaram as construções causativas de forma muito semelhante às construções da língua portuguesa. Segundo Givón (1984), se uma língua tem mais de um tipo formal de causativa, a menor forma será utilizada para expressar uma causação direta, de forma que o número de sílabas ou de segmentos envolvidos na 
operação causativa é iconicamente relacionado à distância entre a causa e o efeito. Em consonância com o estudo teórico de Givón (1984), percebemos que, na Libras, existem especificidades ao apresentar mais de um tipo de construção causativa, porém a maior forma utilizada expressou maior volição, o que foi observado em todos os colaboradores. Analisemos outros dados.

Pensando no roteiro anterior e na prototipicidade da elicitação da construção causativa, em que $O$ menino matou o cachorro apresenta um sujeito (+) agente, que controla o verbo e produz uma ação no paciente (não-humano animado), pensamos num segundo roteiro que contemplasse a inanimacidade antecedendo o verbo. Assim, o segundo roteiro é composto pelos seguintes enunciados:

4) A menina entristeceu.

5) A chuva entristeceu a menina.

6) A chuva fez a menina ficar triste.

Vejamos o resultado em Libras.

Nossa primeira colaboradora, ao ler o enunciado A menina entristeceu sinalizou:
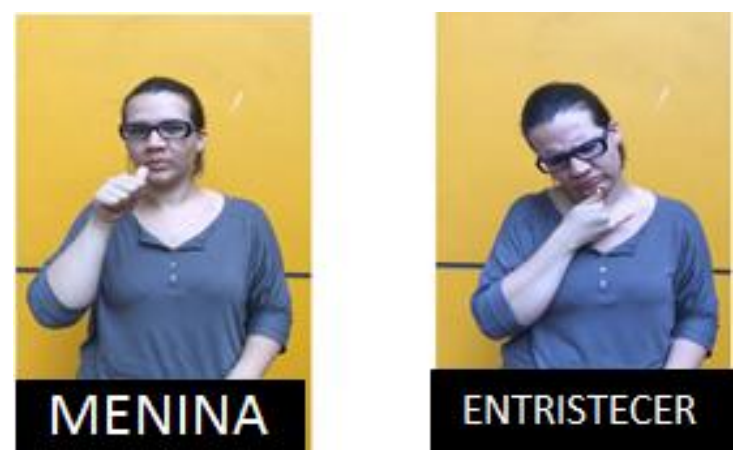

"A menina entristeceu."

Ao ler o segundo enunciado, A chuva entristeceu a menina, a colaboradora sinalizou: 

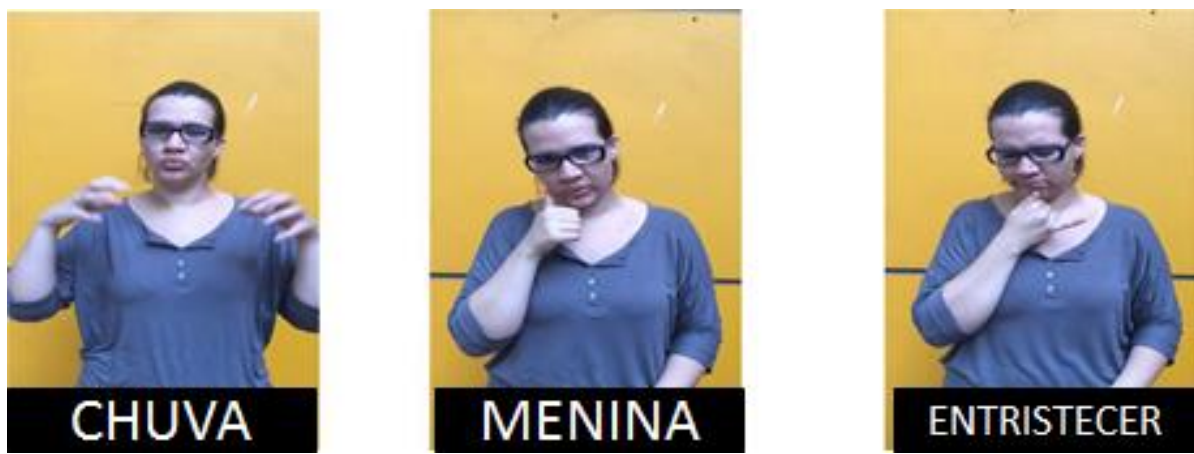

"A chuva, a menina entristeceu."

A construção associa um predicado de causa Chuva fez ao predicado de efeito $a$ menina entristeceu e, ao introduzir o agente na cena, ele foi colocado em posição inicial, tipicamente ocupada pelo sujeito gramatical, porém, a ordem que seria básica na Libras SVO cede lugar para uma construção SOV. Pensamos que essa antecipação do objeto, colocando-o em uma posição pré-verbal, possivelmente ocorreu por tratar-se de argumento [+humano,+animado]. Esse também pode ser um tema de pesquisas futuras.

Analisemos o enunciado seguinte "A chuva fez a menina ficar triste":
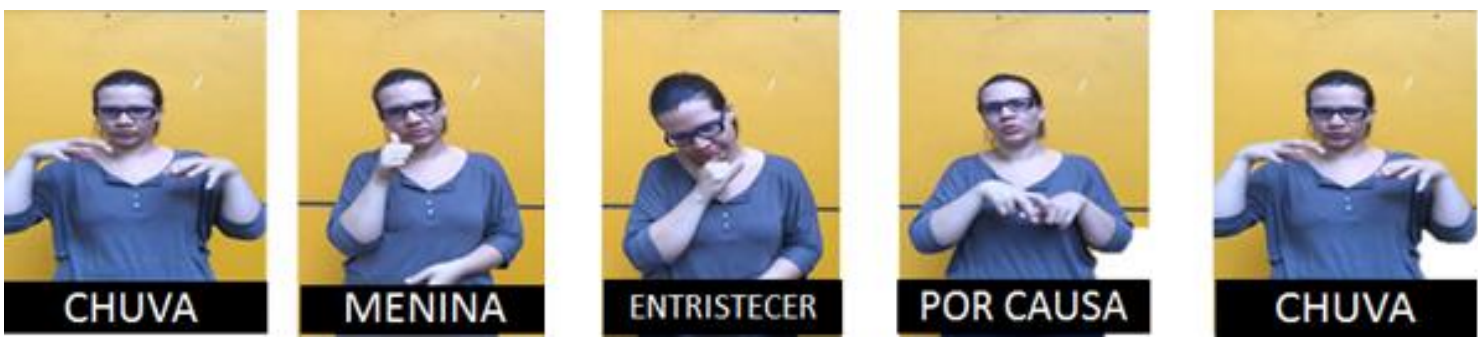

"Chuva, a menina entristeceu por causa da chuva"

Como na sentença anterior, a construção causativa surge a partir do elemento topicalizado, que por sua vez, além de ocupar a posição inicial e de destaque na oração, é retomado no final da sentença, que, somado a expressão-não-manual da colaboradora, corrobora por uma ênfase no superagente, ainda maior. Para Quadros (2004), duplicar partes do discurso tem como finalidade duplicar o elemento merecedor de destaque, na sentença, o causador. Mas "a menina" continuou como o sujeito de "entristecer" e na posição pré-verbal. Isso é um diferencial em relação ao Português, por exemplo. Pensamos que essa manutenção de "menina" como sujeito seja uma forma de manter a importância discursiva do argumento [+animado +humano].

Vejamos o mesmo roteiro com outro colaborador. 
Ao apresentar o enunciado A menina entristeceu, nosso segundo colaborador sinalizou:

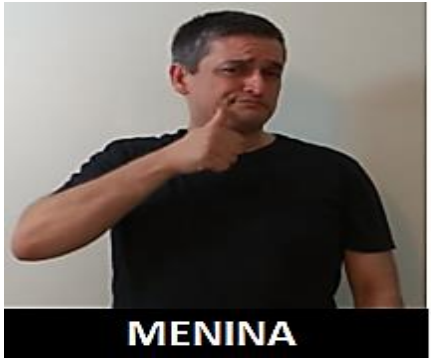

"A menina entristeceu."

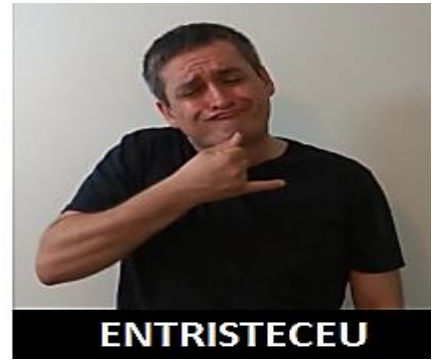

ENTRISTECEU

Na segunda sentença, o colaborador leu A chuva entristeceu a menina e, em Libras:
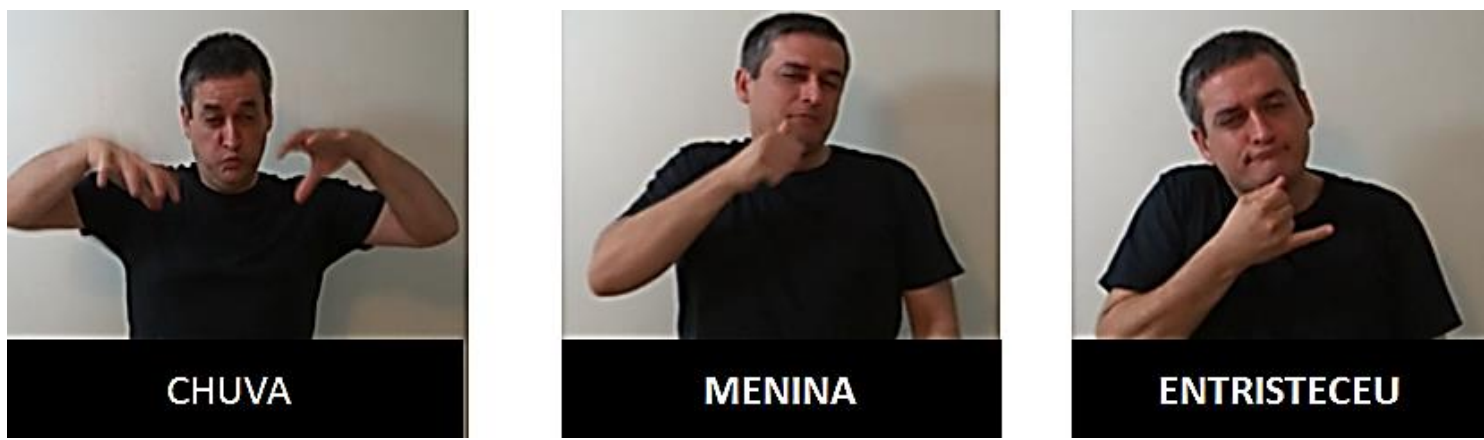

"Chuva, a menina entristeceu."

As escolhas lexicais na construção do enunciado foram as mesmas para os dois colaboradores, porém no enunciado seguinte, correspondente a "A chuva fez a menina ficar triste":
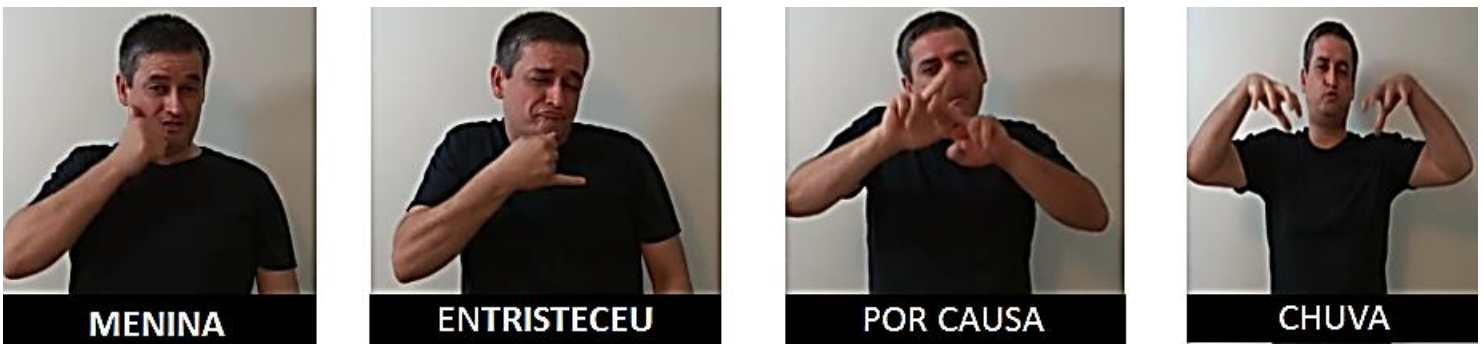

"A menina entristeceu por causa da chuva." 
Notamos que, diferentemente da tradução da sentença 2 anterior, o sinal POR CAUSA foi acrescido no discurso como fez o sinalizante anterior. Os enunciados 2 e 3 apresentam o mesmo conteúdo semântico para expressar a relação de causa-efeito, porém com organização sintática diferente. Afirmar em Libras que a menina entristeceu por causa da chuva seria como construir uma oração de efeito-causa. Talvez, essa troca na ordem seja uma opção do sinalizante, ou ainda, uma forma mais natural de organizar construções causativas, mantendo-se o argumento [+humano + animado] em destaque, como tópico. Observemos mais um colaborador surdo.

O colaborador leu o primeiro enunciado A menina entristeceu e como resultado, em Libras:
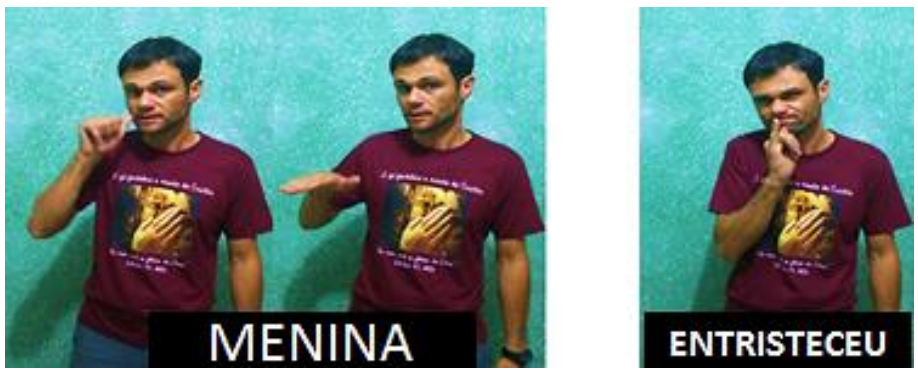

"A menina entristeceu."

Logo após, o colaborador leu o segundo enunciado A chuva entristeceu a menina e traduziu para Libras:
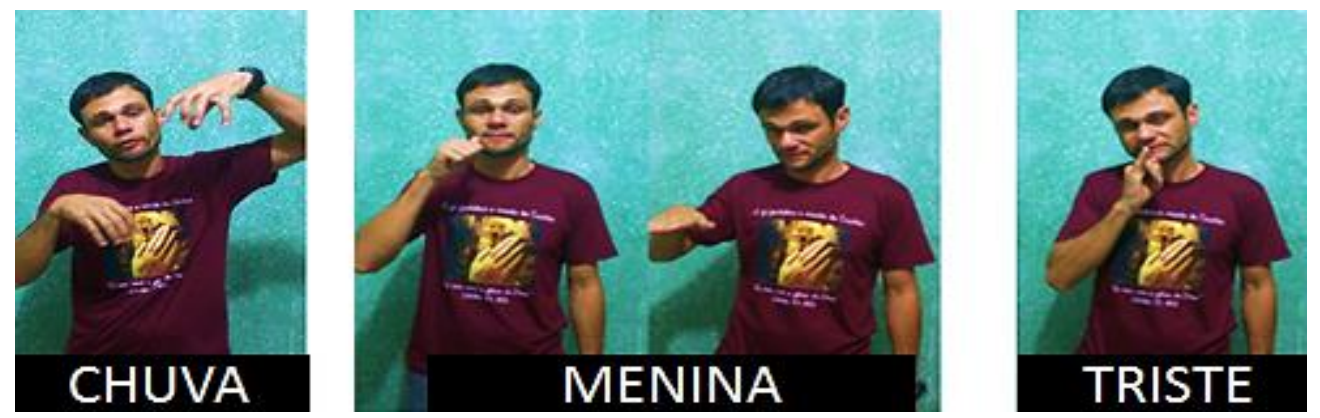

"A chuva, a menina entristeceu."

Percebemos que os três colaboradores traduziram este enunciado para Libras de forma muito semelhante. No último enunciado, o colaborador leu A chuva fez o menino ficar triste e sinalizou: 

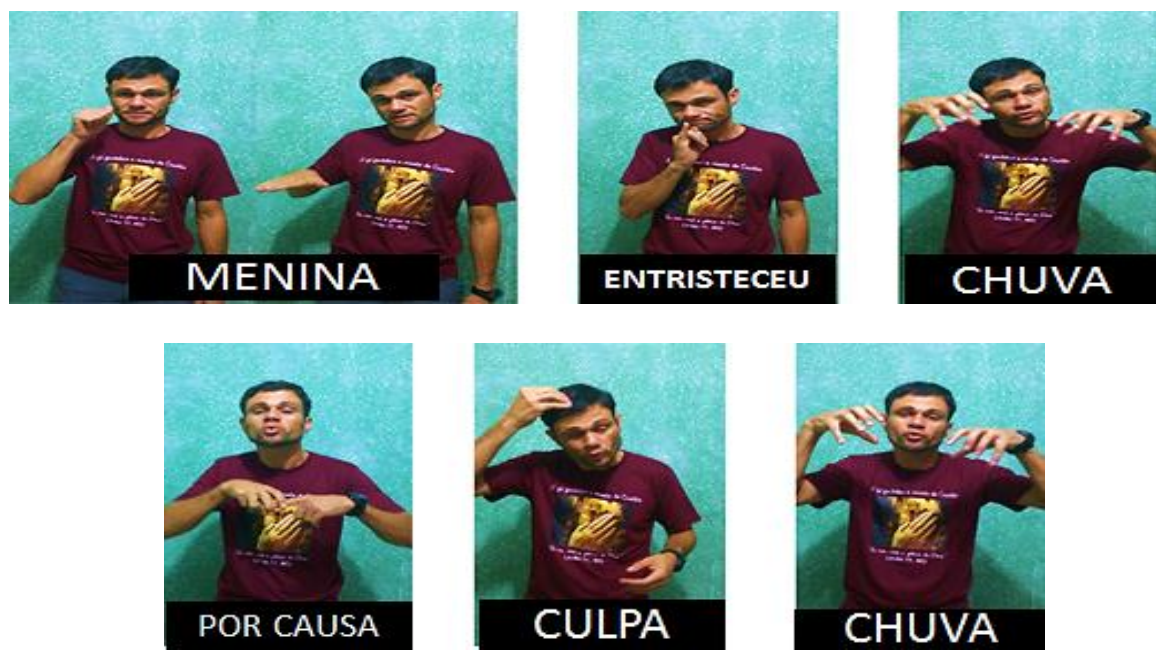

"A menina entristeceu com a chuva, por causa dela, por culpa da chuva."

Sem dúvida, é possível perceber que, como os demais colaboradores, o surdo traz para cena o novo argumento controlando um argumento que já existia, porém, de forma ainda mais peculiar. Inserir no discurso o sinal POR CAUSA já remete à causatividade, mas inserir no mesmo discurso o sinal CULPA significa potencializar a agentividade do causador. Além dos sinais POR CAUSA e [por]CULPA, o constituinte CHUVA é duplicado, como se disséssemos: A menina entristeceu com a chuva. Por causa da chuva, por culpa da chuva, ela, a chuva.

Ao analisar este segundo roteiro, percebemos que nossos colaboradores, de maneira semelhante, inseriram na cena o sinal POR CAUSA em uma das formas de construção causativa, ao ler a chuva fez a menina entristecer. Apesar de não observar o uso deste sinal em outros roteiros analisados com construções causativas, o emprego do sinal foi quase unânime, pelos colaboradores. A manutenção de "menina" como tópico, como sujeito nos chamou a atenção e atribuímos essa manutenção ao fato de ser um argumento [+humano, +animado].

Outro sinal que nos chamou a atenção durante a análise foi o sinal CULPA feito pelo último colaborador, algo recorrente no roteiro anterior. Um fato curioso é que, em Libras, o sinal CULPA tem uma carga semântica ainda maior para atribuir responsabilidade a algo, se comparado com a palavra culpa da língua portuguesa. Em Libras, geralmente o sinal CULPA enfatiza algo ou alguém como responsável por uma situação.

Em um outro momento da pesquisa, conversávamos sobre outra situação hipotética de um garoto cair do skate e machucar o pé. Nessa situação, perguntamos sobre 
as possibilidades das construções causativas em Libras. Um de nossos colaboradores, enquanto falávamos sobre o menino machucar o pé ou o skate fazer o menino machucar $o$ pé, produziu o seguinte dado:

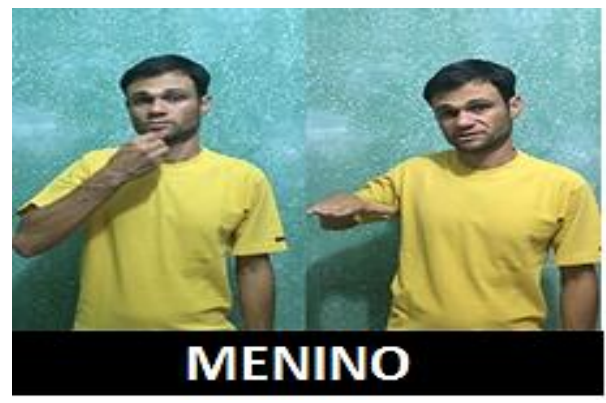

“O menino machucou o pé.”
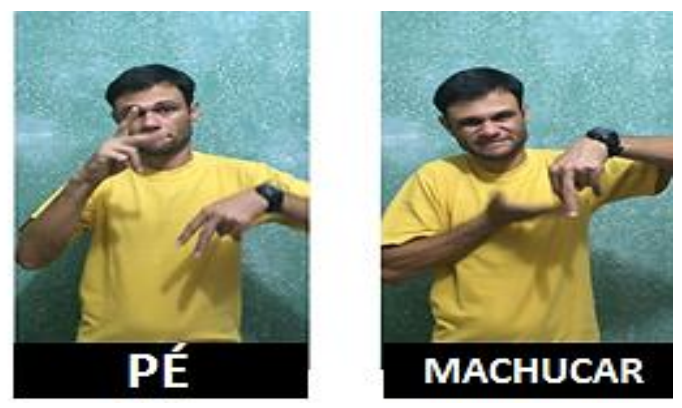
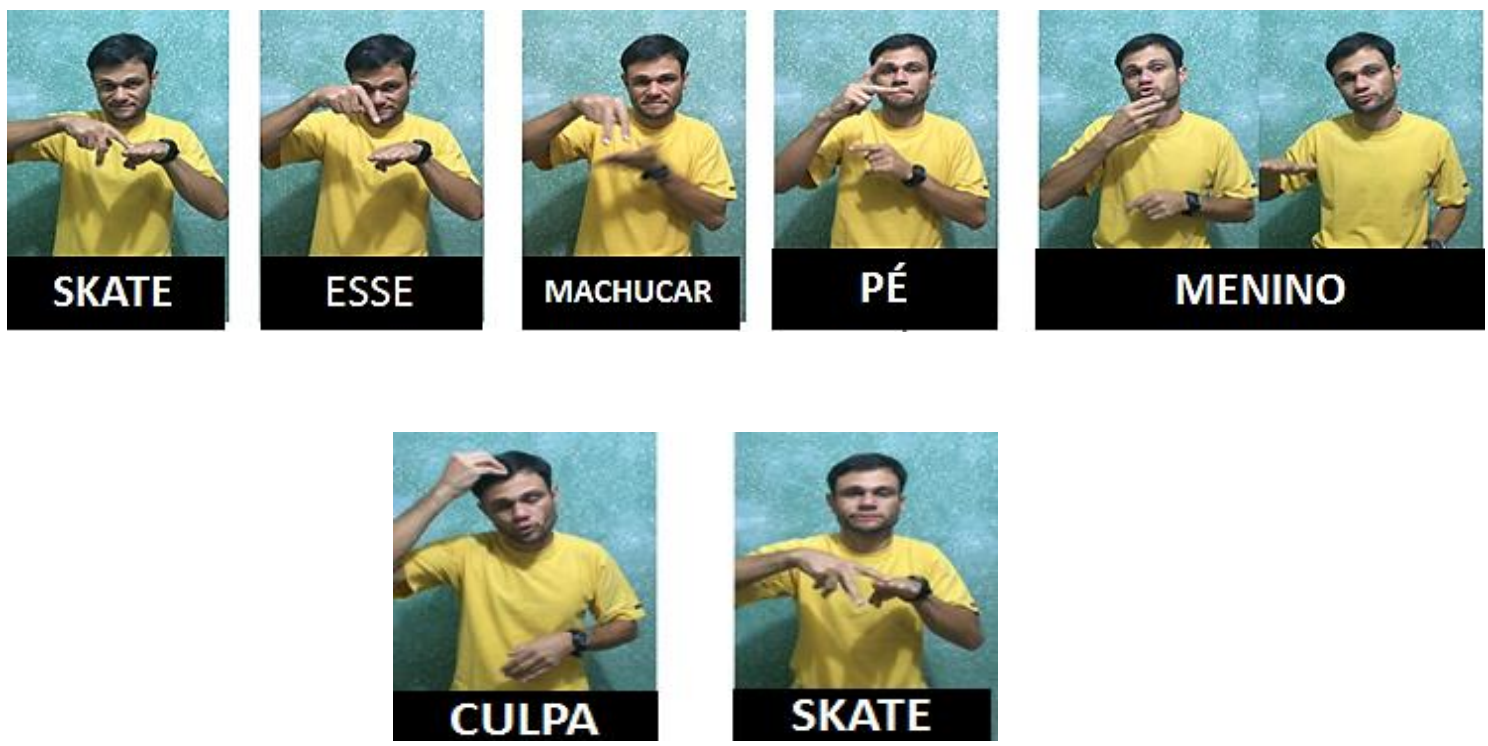

"O skate machucou o pé do menino; a culpa é do skate."

É possível perceber que, além do superagente ser introduzido na cena em uma posição de destaque no enunciado, ele (o skate) por si já carrega a função de causador, porém o colaborador sente a necessidade de mais uma vez evidenciar que é ele $o$ responsável por machucar o pé do menino, ao realizar o sinal de CULPA. Sabemos que a língua dispõe de estratégias de expressão que permitem ao falante construir diferentes enunciados no momento do discurso. Diferentes elementos combinam-se sintaticamente na construção de enunciados que podem apresentar conteúdo semântico semelhante. Assim, haveria outras possibilidades para a construção da sentença, porém o colaborador surdo optou por topicalizar o skate, referenciá-lo mais uma vez, utilizando o recurso da 
apontação (cf. sinal ESSE no segundo quadro), descrever o efeito, o pé do menino machucado, e, mais uma vez trazer o superagente à cena, duplicando a informação de que o pé está machucado e a culpa é dele, a culpa é do skate.

Em português, possivelmente consideraríamos toda essa carga de informação redundante. Em Libras, percebemos discursos como o descrito acima, com retomadas de informação, muito naturais, sobretudo, ao querer colocar em evidência elementos que carecem de mais destaque, como, por exemplo, nesta situação, o causador skate.

Como descrito na metodologia, e pensando em encontrar estratégias causativas na organização de um discurso natural, pesquisamos também alguns vídeos nas redes sociais de surdos sinalizando sobre assuntos diversos. Um assunto que causou muita repercussão na rede foi a falta de uma prova em Libras, durante o último Exame Nacional do Ensino Médio, ENEM. Trechos dos vídeos previamente selecionados foram mostrados a alguns de nossos colaboradores e, na sequência, fizemos a seguinte pergunta:

Por que os surdos não conseguem boas notas no ENEM?

Selecionamos os dados de dois colaboradores em resposta à pergunta. O primeiro colaborador respondeu que:
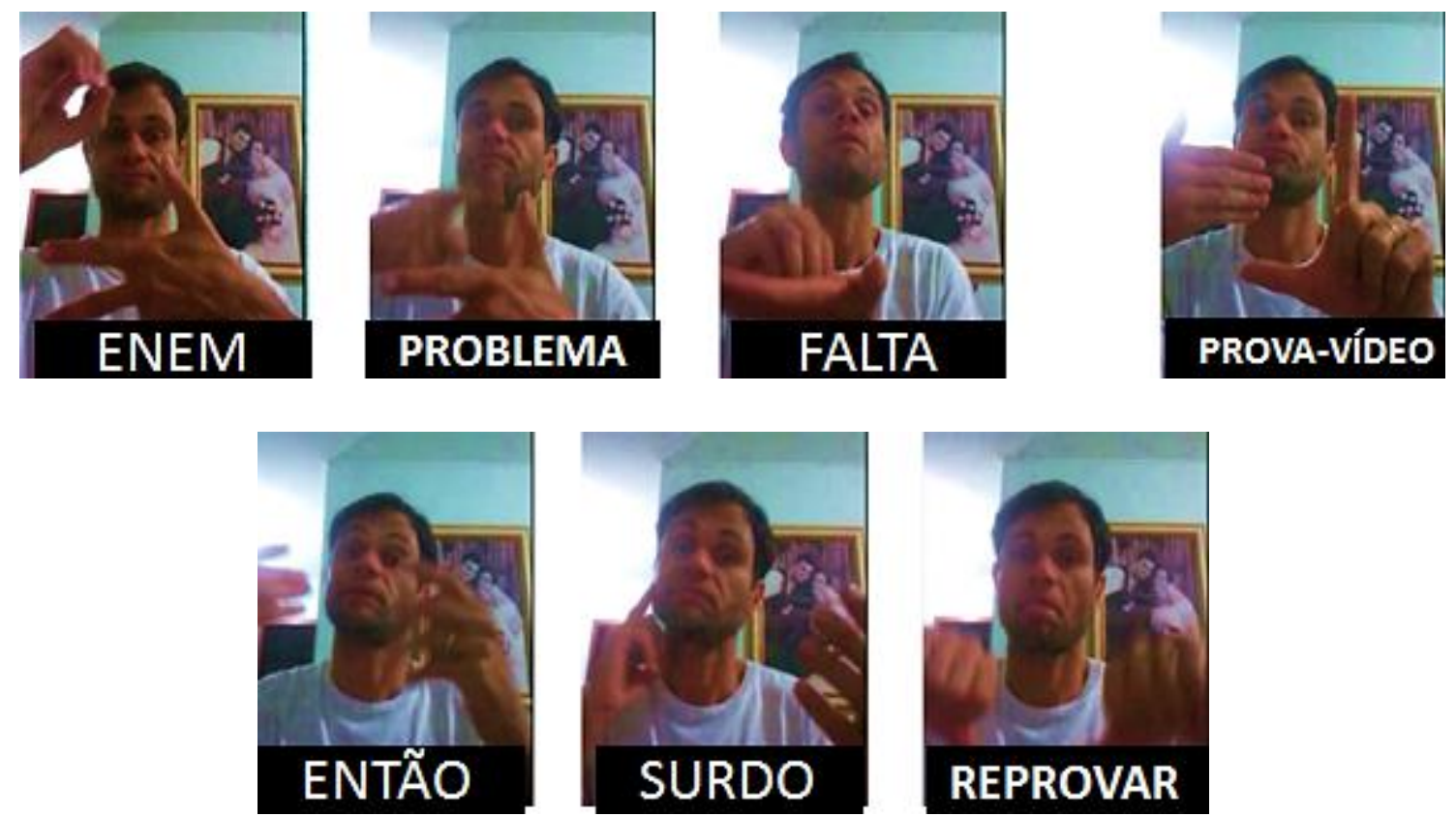

"Enem é problema. A falta de uma prova traduzida em Libras faz os surdos reprovarem." 
A Libras, como tantas outras línguas naturais, utiliza-se de recursos para a manipulação de enunciados. Para Fiorini (2005), um texto manipulador apresenta, dentre tantos outros objetivos, convencer o leitor a aceitar o ponto de vista do enunciador. Sabemos que a falta de uma prova traduzida em Libras é o mesmo que negar acessibilidade aos surdos e observemos a construção da sentença para expressar tal ideia. Inicialmente, o discurso é iniciado por uma oração de topicalização cujo tema é o Enem (ponto de partida da enunciação). O comentário desenvolvido pelo enunciador é de que Enem é sinônimo de problema. Em seguida, inicia-se a construção causativa com o evento-causa A falta da prova em Libras e, na sequência, é dado o evento-efeito: $a$ reprovação dos surdos.

Nossa segunda colaboradora respondeu a mesma pergunta:
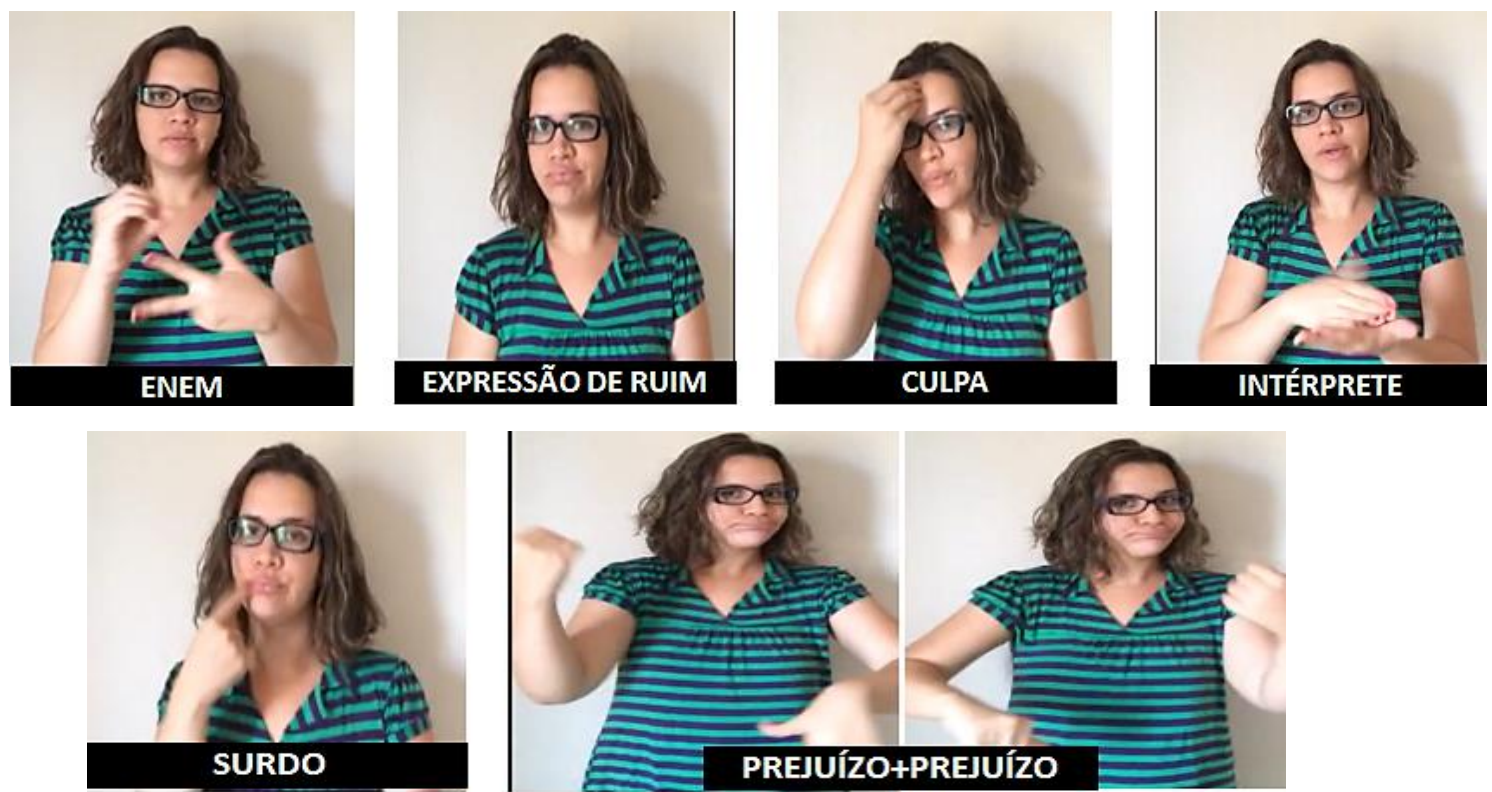

"Enem, horrível e a culpa é do intérprete, que faz que os surdos reprovem (e fiquem no prejuízo).”

A resposta da colaboradora soa como um desabafo sobre a falta de proficiência dos intérpretes que acompanharam o exame. A sentença, da mesma forma que a do colaborador anterior, é iniciada pelo tópico Enem. A colaboradora apresenta sua insatisfação sobre o tema através da expressão-não-manual, possível de ser observada no segundo quadro. Apesar de não haver uma explicação em CULPA INTÉRPRETE, inferese nesta escolha (conforme exemplos anteriores) que a responsabilidade é atribuída ao 
intérprete, que, por sua vez, exerce a função de superagente, da próxima oração, fazer os surdos reprovarem.

\subsection{Considerações do capítulo}

Neste capítulo, apresentamos os dados coletados de nossos colaboradores surdos, analisando cada uma das imagens nas sentenças produzidas. Trabalhamos com diferentes roteiros, inicialmente ilustrado e num outro momento escrito, para que os participantes criassem enunciados em Libras e, a partir do registro filmado destes enunciados, fosse possível a análise dos dados. Após esse processo de entrevista com os participantes, todos os vídeos contendo as elicitações foram analisadas através da ferramenta ELAN, por nos oferecer o suporte necessário para tornar a análise possível. Entre tantos aspectos linguísticos possíveis de serem observados, nos atentamos às construções causativas produzidas pelos colaboradores, objeto da presente pesquisa. Observamos enunciados cuja valência foi aumentada ao trazer às cenas um controlador/causador. Predicados de causa foram associados aos predicados de efeito com a introdução de causadores. Percebemos que a Libras, por ser muito visual, utiliza de estratégias bem peculiares para colocar em evidência, por exemplo o superagente na sentença. Além da posição de destaque inicial na frase, duplica elementos (também tratados pela literatura como “cópia” cf. seção 2.2) para apresentar causador de um evento. 


\section{CAPÍTULO 6 - CONSIDERAÇÕES FINAIS}

Este trabalho teve como finalidade documentar e apresentar uma análise sobre as estratégias usadas em Libras para acrescentar o predicado de causa no discurso causatividade. Embora seja comum encontrar na literatura a descrição desse fenômeno linguístico em diversas línguas orais, não há essa mesma riqueza de análises sobre as línguas de sinais. Ao buscar em Libras, por exemplo, algumas estratégias utilizadas para evidenciar as construções causativas, não encontramos registros. A partir dessa lacuna na análise investigativa, estruturamos a presente pesquisa da seguinte maneira:

1) Apresentamos um panorama histórico das línguas de sinais para o processo de legitimação enquanto língua, com sua definição, reconhecimento científico e características linguísticas das línguas de sinais;

2) Trouxemos um estudo da sintaxe da Libras e uma reflexão sobre esses estudos, porque compreendemos que a sintaxe da sentença e de sua estrutura deve caminhar de mãos dadas com a semântica e a pragmática, aspecto pouco observado em obras consideradas consagradas pela própria literatura. Elegemos, na sintaxe, três principais tópicos pertinentes à análise dos nossos dados e fizemos uma breve explanação: a ordem dos constituintes, os tipos de verbos e a incorporação em Libras;

3) Apresentamos alguns parâmetros da sintaxe funcional-tipológica, corrente norteadora de nosso trabalho e, para isso, focamos nas relações gramaticais e no estudo da ordem, pontos também amplamente observados nas análises dos dados. Uma revisão sobre os estudos da causatividade baseada, sobretudo no continuum de Shibatani \& Pardeshi (2002) foi apresentada, para que pudéssemos observar as construções causativas em diferentes línguas;

4) $\mathrm{Na}$ sequência, descrevemos a metodologia utilizada para a elaboração da pesquisa e, aqui, ressaltamos a dificuldade metodológica encontrada durante o processo. Por tratar-se de uma língua visuoespacial, tivemos de alterar nossa proposta metodológica para garantir maior fidelidade durante a gravação das imagens. Pensamos inicialmente que, a partir de ilustrações, privilegiaríamos dados mais naturais e teríamos, por parte de nossos colaboradores surdos, os dados necessários para realizarmos as análises; porém, apesar dos resultados satisfatórios, algumas dúvidas na compreensão do desenho nos motivaram a 
recorrer a textos e enunciados escritos, em português, para conseguirmos os dados necessários à análise; e

5) Analisamos em nossos dados como ocorrem as construções causativas e, sobretudo, como o superagente é introduzido na cena discursiva.

Com a estrutura adotada na presente pesquisa descrita acima, foi possível perceber que, na Libras, as construções causativas são utilizadas com bastante frequência na enunciação e, assim como muitas línguas orais, os sinalizantes organizam os constituintes da oração para construir situações causativas, de forma muito natural. A Libras tem causativa perifrástica. Alguns resultados nos despertaram ainda maior interesse. Os dados revelaram, por exemplo, que em Libras, quando a causação é deliberada, vem sempre mais marcada, com mais material linguístico que a outra causação menos volitiva. Outra revelação interessante é a de que alguns sinais aparecem no discurso do surdo para evidenciar maior volição aos processos, sobretudo ao remeter a prototipicidade semântica ao agente da ação, como observado nos enunciados $O$ menino fez o copo cair ou em $O$ menino fez o cachorro morrer. Os colaboradores acresceram sinais como CULPA, MALDADE e CRUELDADE para evidenciar a volição, animacidade e controle da ação do superagente. Essa (super)valorização do superagente e de sua volição também tornamse evidentes nas repetições de partes do discurso (observada nos dados). Os dados revelaram ainda aspectos interessantes quanto à ordem em Libras, sobretudo quando a sentença apresenta um argumento [+humano +animado] na posição de objeto. A mudança de ordem, nesse caso, foi bastante recorrente.

Entendemos que a presente pesquisa é mais um passo alcançado na caminhada da descrição da Libras e das línguas de sinais; porém, compreendemos também que muitos aspectos linguísticos carecem ser analisados, por ainda não serem descritos na literatura atual. Esperamos, assim, ter contribuído com a linguística da Libras. 


\section{REFERÊNCIAS BIBLIOGRÁFICAS}

AMARAL, V.M. Sistema de transcrição da língua brasileira de sinais voltado à produção de conteúdo sinalizado por avatares 3D. Tese (Doutorado em Engenharia Elétrica) - Faculdade de Engenharia Elétrica e de Computação, Universidade de Campinas, SP.

BAKER, C. \& PADDEN. C. American Sign Language: a look at its history, structure, and community. Silver Spring, Md.: T.J. Publishers, Inc. 1978.

BAKER, C. Eye-openers in ASL. Sixth California Linguistics Association Conference: Proceedings, $1-13,1976$.

BATTISON, R. Lexical borrowing in American Sign Language. Silver Spring. MD: Linstok, 1978.

BEHARES, L.E. Nuevas corrientes en la educación del sordo: de los enfoques clínicos a los culturales. Cadernos de Educação Especial, 1(4): 20-53, Santa Maria: Universidade Federal de Santa Maria, 1993.

BENVENISTE, E. Problemas de linguística geral I. Campinas. Pontes, 2005.

BRASIL. Decreto $n^{0} 5626$ de 22 de dezembro de 2005. Brasília: Presidência da República, Casa Civil, Subchefia para Assuntos Jurídicos. Disponível em:http://www.presidencia.gov.br/ccivil/_Ato2004-2006/2005/Decreto/D5626.htm.

Acesso em:10 outubro de 2013.

BRASIL. Lei $\mathbf{n}^{\mathbf{0}} \mathbf{1 0 . 4 3 6}$, de 24 de abril de 2002. Dispõe sobre a Língua Brasileira de Sinais - LIBRAS e dá outras providências. Diário Oficial [da] República Federativa do Brasil, Poder Executivo, Brasília, DF, 25 abr. 2002. n. 79, ano CXXXIX, Seção 1, p. 23. Disponível em: http://www.planalto.gov.br/ccivil_03/leis/2002/110436.htm. Acesso em 10 de outubro de 2013.

CHAFE, W. L. Discourse, consciousness and time. Chicago: The University of Chicago Press, 1994.

COMRIE, B. Causative verb formation and other verb-deriving morphology. In: Shopen, T. (ed.). Language typology and syntactic description. Vol. 3: Grammatical categories and the lexicon. Cambridge: Cambridge University Press. 309-348, 1985.

COMRIE, B. Ergativity, in W. P. Lehmann (ed.), Syntactic Typology. Studies in the Phenomenology of Language, The University of Texas Press, Austin, pp. 329-394, 1978.

COMRIE, B. Language Universals and Linguistic Typology: Blackwell, Oxford: 2nd ed, 1989.

CORTEZ, Cinara Monteiro. Formalismo x Funcionalismo: abordagens excludentes?. Percursos Linguísticos. Vitória-ES, v.1, n. 1. p. 57-77, 2011. 
COSTA, M. R. Proposta de modelo de enciclopédia visual bilíngue juvenil: enciclolibras. 2012. 151 f., il. Dissertação (Mestrado em Linguística). Universidade de Brasília, Brasília, 2012.

CRATO, A. N. Marcação de tempo por surdos sinalizadores. 2010. 114f. Dissertação (Mestrado em Ciências da Reabilitação). Universidade de São Paulo, 2010.

CUNHA, M. A. F. da; OLIVEIRA, M. R. \& MARTELOTTA, M. E. Martelotta (orgs.). Lingüística funcional: teoria e prática. Rio de Janeiro: DP\&A/ Faperj, 2003.

DIXON, R. M. W. Ergativity. Cambridge: Cambridge University Press, 1994.

FELIPE, T. A. Libras em Contexto: Curso Básico: Livro do Estudante. Rio de Janeiro: WalPrint Gráfica e Editora, 2009.

FERNANDES, E. Parecer solicitado pela Federação Nacional de Educação e Integração do Surdo sobre a Língua de Sinais usada nos centros urbanos do Brasil. In Revista Integração. MEC/Secretaria de Educação Especial, ano 5, nº 13, p. 18- 21, 1994.

FERREIRA, L. Por uma gramática de línguas de sinais. Rio de Janeiro: Tempo Brasileiro, 2010.

FIORIN, J. L. Elementos de Análise do Discurso. São Paulo: Contexto, 2005.

FISHER, S. D. Two Processes of Reduplication in the American Sign Language. In Foundations of Language 9: 469-480, 1973.

FRISHBERG, N., \& GOUGH, B. Morphology in American Sign Language. California: Salk Institute Working Paper, 1973.

GERALDI, João Wanderley (org.) O texto na sala de aula. Cascavel: Assoeste, 1984.

GESSER, A. LIBRAS? Que língua é essa? Crenças e Preconceitos em torno da língua de sinais e da realidade surda. São Paulo: Parábola Editorial, 2009.

GIVÓN, T. From discourse to syntax: grammar as a processing strategy - Syntax and Semantics vol.12 Discourse and Syntax. New York: Academic Press, 1979.

GIVÓN, T. Syntax and semantics: discourse and syntax. New York: Academic Press, 1979.

GIVÓN, T. Syntax: a Functionl - Typological Introduction. Vol. I e II. Amsterdam and Philadelphia: JBPC, 2001.

GOLDFELD, M. A criança surda: linguagem e cognição numa perspectiva sóciointeracionista. São Paulo: Ed. Plexus, 1997. 
GOMES, D. M. Estudo morfológico e sintático da língua Mundurukú (Tupí). 2006. 320f. Tese (Doutorado em Linguística) - Departamento de Lingüística, Línguas Clássicas e Vernácula, Brasília: UnB, 2006.

GOMES, D. M.Voz e Valência Verbal em Mundurukú (Tupí). In: BRUNO, A. C. QUEIXÁLOS, F., TELLES, S. (orgs) Incremento de Valencia em Las Lenguas Amazónicas. Universidad Nacional de Colombia. Bogotá, 2014. Disponível em: http://qxls.free.fr/QxlsProf/CyC/ValenciaToutCorrecQxlsAvril.pdf. Acesso em: 14/12/2014.

HALLIDAY, M. A. K.; HASAN, R. Language, context and text: aspects of language in a socialsemiotic perspective. Oxford: Oxford University press, 1989.

HANKS, W. F. Língua como prática social: das relações entre língua, cultura e sociedade a partir de Bourdieu e Bakhtin. BENTES, A. C.; REZENDE, M. A. R. M. (orgs.) São Paulo: Cortez, 2008.

KINKADE, M. D. Salish evidence against the Universality of 'Noun' and 'Verb. Língua 60, 25-40, 1983.

KLIMA, E. \& BELLUGI, U. The signs of language. Cambridge, Mass.:Harvard University Press. 1979.

LEITE, T. A. A segmentação da língua de sinais brasileira (libras): um estudo linguístico descritivo a partir da conversação espontânea entre surdos. Tese (Doutorado em Letras) - Faculdade de Filosofia, Letras e Ciências Humanas. São Paulo: Universidade de São Paulo, 2008.

LIDDELL, S. K Grammar, gesture and meaning in American Sign Language. Cambridge: Cambridge University Press, 2003.

LIDDELL, S. K. Non-manual signals and relative clauses in ASL. In Siple, 1978.

LIDDELL, S. K. THINK and BELIEVE: Sequentiality in American Sign Language. Language, v. 60, n. 2, p. 372-399, 1984.

LIMA, E. S. Discurso e identidade: um olhar crítico sobre a atuação do(a) intérprete de LIBRAS na educação superior. 2006. 175 f. Dissertação (Mestrado em Linguística), Brasília: Universidade de Brasília, 2006.

LOPES, E. Fundamentos da Linguística Contemporânea. São Paulo. Ed. Cultrix. 1980.

LYONS, J. Introdução à Linguística Teórica. São Paulo, Nacional/EDUSP, 1979.

LYONS, J. Linguagem e Linguística: uma introdução. Tradução Marilda Winkler Averburg, Clarisse Sieckenius de Souza. Rio de Janeiro: LTC, 2009.

MARCUSCHI, L. A. Da fala para a escrita: atividades de retextualização. 9 ed. São Paulo: Cortez, 2008. 
MARTINS, A. P. P. Funcionalismo linguístico: um breve percurso histórico da Europa aos Estados Unidos. Domínios de Linguagem. Ano 3, nº 2, 2009.

McCLEARY, L.; VIOTTI, E.; LEITE, T. A. Sign language description: the role of transcription. São Paulo: Alfa, v. 54, n. 1, p. 265-289, 2010.

MEIR, I. Syntactic-semantic interaction in Israeli Sign Language verbs: The case of backwards verbs. Sign Language and Linguistics. Disponível em: http://sandlersignlab.haifa.ac.il/irit_articles/Meir_SLL_1998.pdf. Acesso em: 14/02/2013.

MILLER, C. A note on notation. Sign Post: v. 7(3), 191-202. Durham: University of Durham, 1994.

MITHUN, M. The evolution of noun incorporation. Languag. 60:4, p. 847-894. Linguistic Society of America, 1984.

NASCIMENTO, S. P. de F. Representações léxicas da língua de sinais brasileira: uma proposta lexicográfica. 290f. Tese. (Doutorado em Linguística). Brasília: Universidade de Brasília, 2009.

NEVES, M. H. de M. A gramática funcional. São Paulo: Martins Fontes, 1997.

NEVES, M. H. de M.. Gramática de usos do português. São Paulo: EDUNESP, 2000.

PADDEN, C. \& PERMULTTER, D., American Sign Language and the architecture of phonological theory. Natural Language and Linguistic Theory, 5. 14 pages. 1987.RESEARCH ARTICLE

PAYNE, T. E. Describing morphosyntax - a guide for field linguists. New York: CUP, 1997.

PEZATTI, E. G.; CAMACHO, Roberto Gomes (1997). Aspectos funcionais da ordem de constituintes. D.E.L.T.A. São Paulo. vol.13, n.2, p. 191-214.

PIZZIO. A. L. A Tipologia Linguística e a Língua de Sinais Brasileira: Elementos que distinguem nomes de verbos. 2011. 237f. Tese (Doutorado em Linguística). Universidade Federal Santa Catarina, 2011.

QUADROS, R. M. de \& KARNOPP, L. B. Língua de Sinais Brasileira: Estudos linguísticos. Porto Alegre: Artmed, 2004.

QUADROS, R. M. de \& PIZZIO, A. L.; REZENDE, P. L. F. Língua de Sinais Brasileira I. Apostila. Florianópolis, 2009. UFSC.

QUADROS, R. M. de \& QUER, J. A caracterização da concordância nas línguas de sinais. In: Salles, H.; Naves, R. (orgs.) Estudos gerativos de língua de sinais brasileira e de aquisição de Português (L2) por surdos. Goiânia: Cânone Editorial, 2010. 
QUADROS, R. M. de. Contextualização dos estudos linguísticos sobre a Libras no Brasil. In: QUADROS, R. M. de; STUMPF, M. R.; LEITE, T. de A. Estudos da Língua Brasileira de Sinais I. Florianópolis: Editora Insular, 2013.

QUEIXALÓS, F. Ergatividade em Katukína' in Ergatividade na Amazônia I, Brasília, Universidade de Brasília, 2002.

QUEIXÁlOS, F., TELLES, S. (orgs) Incremento de Valencia em Las Lenguas Amazónicas. Bogotá: Universidad Nacional de Colombia, 2014. Disponível em: http://qxls.free.fr/QxlsProf/CyC/ValenciaToutCorrecQxlsAvril.pdf. Acesso em: $14 / 12 / 2014$.

SÁ, N. R. L. Cultura, poder e educação de surdos. Manaus. Editora da Universidade Federal do Amazonas, 2002.

SANDLER, W. Sign Language Phonology. In William Frawley (Ed.), The Oxford International Encyclopedia of Linguistics, 2003. Disponível em: http://sandlersignlab.haifa.ac.il/wendy.htm. Acesso em 18/07/2013,

SANDLER, W. Phonological Representation of the Sign: Linearity and Nonlinearity in American Sign Language, Dordrecht: Foris, 1989.

SHIBATANI, M. \& PARDESHI, P. The causative Continuum. In: The Grammar of Causation and Interpersonal Manipulation, Masayoshi Shibatani (ed.), 85-126 (Typological Studies in Language 48.) Amsterdam, Philadelphia: John Benjamins, 2002.

SHIBATANI, M. The grammar of causative constructions: a conspectus. In Syntax and Semantics 6 The grammar of causative constructions, New York: ed. Masayoshi, 1976.

SILVERSTEIN, M. Hierarchy of features and ergativity. In DIXON, R.M.W (ed.) (1976). Gammatical categories in Australian languages. Camberra: Australian ainstitut of Aboriginal Studies -71-112. Z

STOKOE W.C. Sign language structure: as outline of the visual communication system for the American deaf. Buffalo, Nova York: Buffalo University, 1960.

STROBEL K. As Imagens do Outro sobre a Cultura Surda. Florianópolis: Ed. UFSC, 2008.

STROBEL, K. \& FERNANDES, S. Aspectos Linguísticos da Libras: Língua Brasileira de Sinais. Disponível em: file:///C:/Users/Jo\%C3\%A3oPaulo/Downloads/aspectoslinguisticosLibras.pdf. Acesso em: 03/10/2013. SEED/SUED/DEE, 1998.

STUMPF, M. R. Escrita de Sinais I. (Apostila) Florianópolis: UFSC, 2008.

VIOTTI, E. de C. Introdução aos Estudos Linguísticos. (Apostila) Florianópolis: Departamento de Artes Cências, Cinema e Libras, 2008. 67f. 
VOTRE, S. J e RONCARATI, C. (orgs.) Anthony Julius Naro e a linguística no Brasil: uma homenagem acadêmica. Rio de janeiro: Editora 7 Letras, 2008.

XAVIER, A. N. Descrição fonético-fonológica dos sinais da língua brasileira de sinais (libras). 2006. 175 f. Dissertação (Mestrado em Linguística). Faculdade de Filosofia, Letras e Ciências Humanas, Universidade de São Paulo, São Paulo. 


\section{APÊNDICE A}

\section{QUESTIONÁRIO SOCIOLINGUÍSTICO}

Data

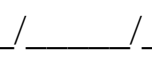

1- Nome:

2- Nascimento:

3- Naturalidade:

4- Causa da surdez:

5- Data de diagnóstico da surdez:

6- Escolarização:

7- Conhecimento de LIBRAS - Aprendeu com qual idade?

( ) aprendeu na escola

( ) aprendeu antes de entrar na escola

( ) aprendeu depois de entrar na escola

8- Proficiência em LIBRAS:

( ) Muito bom

( ) Bom

( ) Regular

( ) Insuficiente

( ) Nenhum

9- Conhecimento de português escrito:

( ) Muito bom

( ) Bom

( ) Regular

( ) Insuficiente

( ) Nenhum 


\section{APÊNDICE B}

\section{Termo de Consentimento Livre e Esclarecido}

Você está sendo convidado a participar da pesquisa CAUSATIVIDADE EM LIBRAS. De responsabilidade de Alliny de Matos Ferraz Andrade, aluna de mestrado da Universidade de Brasília. O objetivo desta pesquisa é investigar como ocorre a causatividade em Libras. Assim, gostaria de consultá-lo(a) sobre seu interesse e disponibilidade de cooperar com a pesquisa.

Você receberá todos os esclarecimentos necessários antes, durante e após a finalização da pesquisa. Os dados provenientes de sua participação na pesquisa, tais como questionários, entrevistas, fitas de gravação ou filmagem, ficarão sob a guarda do pesquisador responsável pela pesquisa.

A coleta de dados será realizada por meio de gravações de vídeo. É para estes procedimentos que você está sendo convidado a participar. Sua participação na pesquisa não implica em nenhum risco.

Espera-se com esta pesquisa analisar e descrever fenômenos linguísticos da Língua Brasileira de Sinais.

Sua participação é voluntária e livre de qualquer remuneração ou benefício. Você é livre para recusar-se a participar, retirar seu consentimento ou interromper sua participação a qualquer momento. A recusa em participar não irá acarretar qualquer penalidade.

Se você tiver qualquer dúvida em relação à pesquisa, você pode me contatar através do telefone 61 8143XXXX ou pelo e-mail allinyandrade@ gmail.com.

A equipe de pesquisa garante que os resultados do estudo serão devolvidos aos participantes, caso haja solicitação.

Este documento foi elaborado em duas vias, uma ficará com o(a) pesquisador(a) responsável pela pesquisa e a outra com o senhor(a).

Assinatura do (a) participante

Assinatura do (a) pesquisador (a)

Brasília, de de 